\title{
Um instrumento de avaliação da qualidade para software educacional de Matemática
}

Ana Paula Gladcheff

DISSERTAÇÃO APRESENTADA

$\mathrm{AO}$

INSTITUTO DE MATEMÁTICA E ESTATÍ́STICA

DA

UNIVERSIDADE DE SÃO PAULO

PARA

OBTENÇÃO DO GRAU DE MESTRE

EM

CIÊNCIA DA COMPUTAÇÃO

\begin{abstract}
Área de Concentração: Ciência da Computação
Orientadora: Prof.a Dra. Dilma Menezes da Silva
\end{abstract}

Durante o desenvolvimento deste trabalho, a autora recebeu apoio financeiro da FAPESP. Processo n ${ }^{\circ}$ 98/02569-9

- São Paulo, fevereiro de 2001- 
Um instrumento de avaliação da qualidade para software educacional de Matemática

Este exemplar corresponde à redação final da dissertação devidamente corrigida e defendida por Ana Paula Gladcheff e aprovada pela comissão julgadora.

São Paulo, 09 de fevereiro de 2001

Banca examinadora:

- Prof.a Dra. Dilma Menezes da Silva (orientadora) (IBM Research)

- Prof. Dr. José Carlos Maldonado (ICMC-USP)

- Prof.a Dra. Edna Maura Zuffi (ICMC-USP) 
Ao meu marido e amigo, Fábio Munhoz, pelo amor e companheirismo...

Aos meus pais, Elias e Thereza, pelo apoio constante... 
Aos especialistas entrevistados: Prof.a Ana Maria D. G. Hessel, Prof.a Consuelo Fernandez, Prof. Josenilton A. Franca, Prof. Leônidas O. Brandão, Prof.a Marilia Basili e Prof.a Dr.a Vera B. Oliveira, pela disposição com que me atenderam e pelo compartilhamento de suas experiências.

Aos integrantes do CAEM e aos professores que colaboraram com as avaliações dos softwares: Prof.a Adilia, Prof. Altair, Prof.a Cristina, Prof.a Doralice, Prof.a Dorli, Prof.a Eliana, Prof. Marco Antônio e Prof.a Maria de Fátima, pela atenção.

Aos amigos do IME-USP e do ICMC-USP, pela amizade e companheirismo.

À FAPESP, ao Instituto de Matemática e Estatística da Universidade de São Paulo, aos integrantes da biblioteca do IME-USP e às bibliotecárias do ICMC-USP. 
I INTRODUÇÃO .................................................................................................................1

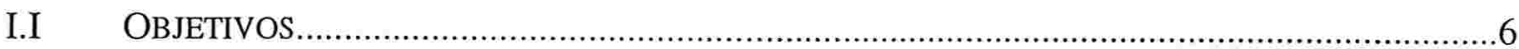

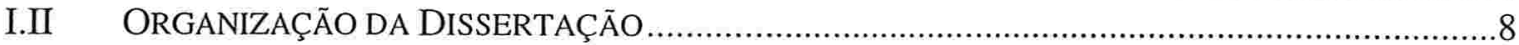

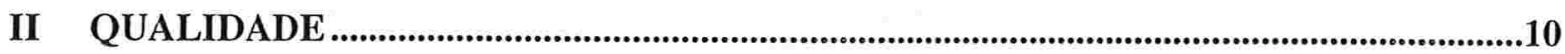

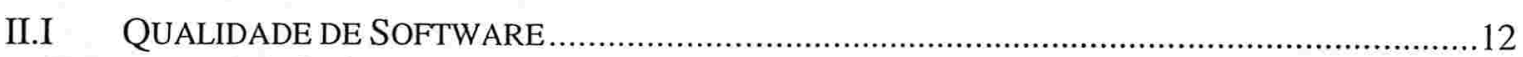

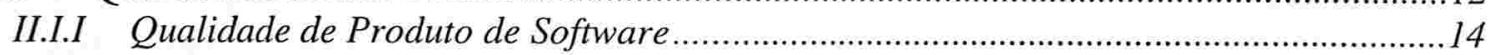

II.I.II A Característica de Qualidade Usabilidade .............................................................20

III A INFORMÁTICA NA EDUCAÇÃO ....................................................................................25

III.I TENDÊNCIAS IDENTIFICADAS NA TRADIÇÃO PEDAGÓGICA BRASILEIRA ............................25

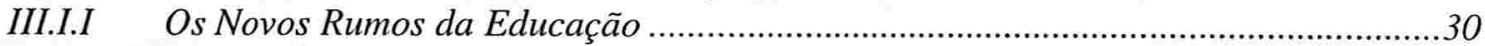

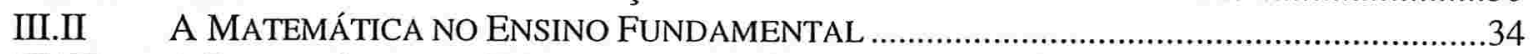

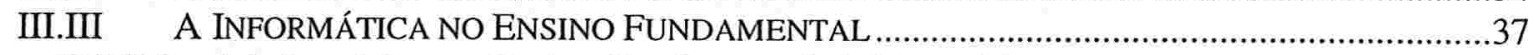

III.III.I A Informática no Ensino Fundamental de Matemática .................................................43

III.IV AS DIFERENTES MODALIDADES DO SOFTWARE EDUCACIONAL ...................................4

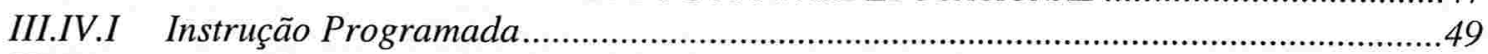

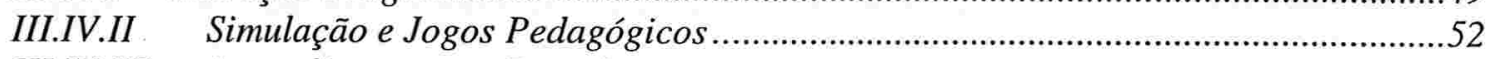

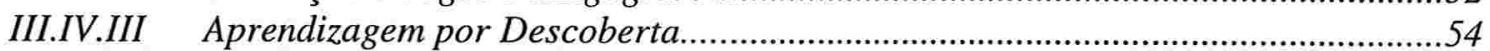

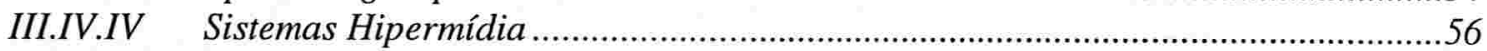

III.V AVALIAÇÃO DA QUALIDADE DO SOFTWARE EDUCACIONAL ……..................................58

III.VI AS MODALIDADES DE SOFTWARE EDUCACIONAL CONTEMPLADAS NO INSTRUMENTO

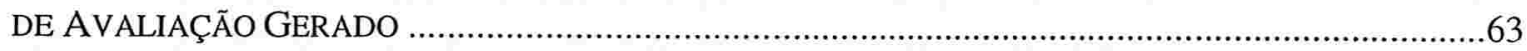

III.VII A PRODUÇÃO NO BRASIL DE SOFTWARE EDUCACIONAL DE MATEMÁTICA,

DIRECIONADO AO ENSINO FUNDAMENTAL

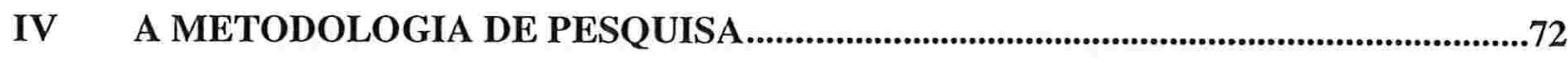

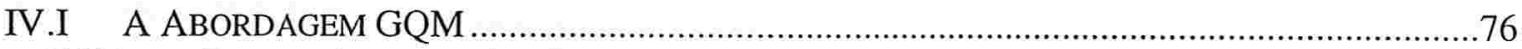

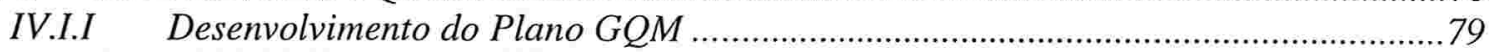

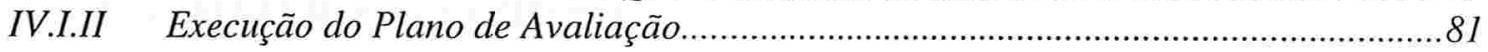

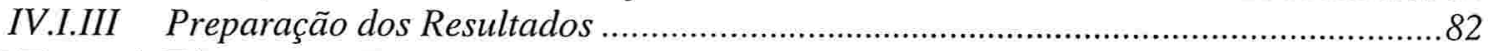

IV.II A TÉCNICA DE ENTREVISTA PARA AQUISIÇÃO DE CONHECIMENTO EXPLÍ́CITO ............83

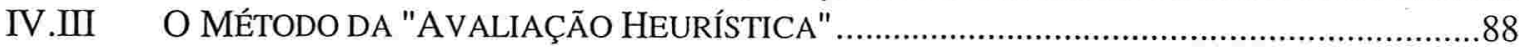

V DESENVOLVIMENTO DO TRABALHO

V.I PRIMEIRA UTILIZAÇÃO DO MÉTODO GQM - OBTENÇÃO DE CONHECIMENTO JUNTO A

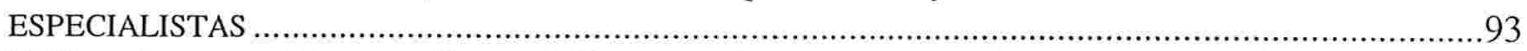

V.II SEGUNDA UTILIZAÇÃO DO MÉTODO GQM - ELABORAÇÃO DO QUESTIONÁRIO PARA

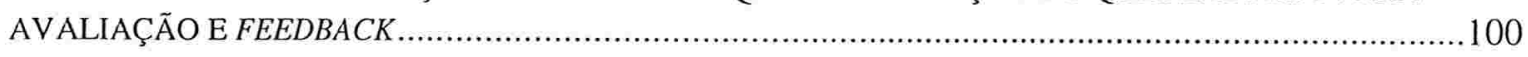

V.III TERCEIRA UTILIZAÇÃO DO MÉTODO GQM - ELABORAÇÃO DO QUESTIONÁRIO PARA AVALIAÇÃO DA CARACTERÍSTICA "USABILIDADE" DO PRODUTO DE SOFTWARE . 


\section{ÍNDICE DE FIGURAS}

FIGURA 2.1 - ANÁLISE dOS REQUISITOS DE QUALIDADE.

FIGURA 2.1.2.1 - ATRIBUTOS DE ACEITABILIDADE DE SISTEMAS.

FIGURA 4.1.1 - ETAPAS E FASES DO PROCESSO GQM.

FIGURA 4.2.1 - FORMULÁRIO DE AQUISIÇÃO DE CONHECIMENTO.

FIGURA 4.2.2 - ADAPTAÇŌES E RESUMOS DE ALGUMAS TÉCNICAS DE FECHAMENTO VERBAL.

FIgURA 5.1.1 - ESQUEMA RESUMIDO DAS ATIVIDADES REALIZADAS DURANTE A $1^{\text {A }}$ UTILIZAÇĀo DO MÉTODO GQM

Figura 5.2.1 - Esquema Resumido das ATIVIdades REalizadas DURANTE A $2^{A}$ UTILIZAÇĀo do MÉTOdo GQM

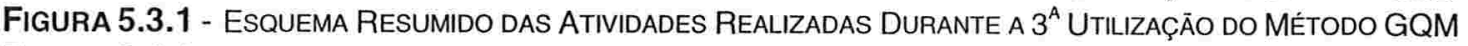

Figura 6.4.1 - ESTRUTURA dO RELATÓRIO SOBRE O SOFTWARE AVALIADO.

Figura 6.4.2 - ESTRUTURA dO RELATÓRIO SOBRE O SOFTWARE AVALIADO (CONT.).

Figura 6.4.3 - ESTRUTURA dO RELATÓRIO SOBRE O SOFTWARE AVALIADO (CONT.).

Figura 6.4.4 - ESTRUTURA do RELATÓRIO SOBRE O SoftWARE AVALIAdo (CONT.).

\section{ÍNDICE DE TABELAS}

TABELA 2.1.1.1 - CARACTERÍSTICAS DA QUALIDADE DE SOFTWARE SEGUNDO A ISO/IEC 9126-1.

TABELA 2.1.1.2 - SUBCARACTERÍSTICAS DA QUALIDADE DE SOFTWARE SEGUNDO A ISO/IEC 9126-1.

TABELA 3.1.1.1 - ESTÁGIOS dO DESENVOLVIMENTO COGNITIVO PIAGETIANO.

TABELA 4.3.1 - CONJUNTO DE HEURISTICAS DE USABILIDADE.

TABELA 4.3.2 - RELAÇĀO dOS ATRIBUTOS DE USABILIDADE COM AS HEURISTICAS.

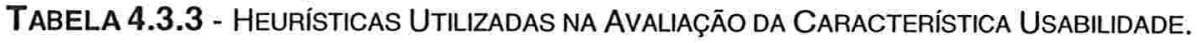




\section{Capítulo 1}

\section{INTRODUÇÃO}

O impacto da Informática na educação tem sido tema de crescente inquietação entre educadores, sobretudo pela velocidade com que os computadores vêm ganhando espaço no cotidiano social [Monteiro93]. Estas máquinas exercem um poder de fascinação muito grande sobre alunos e professores. Os professores devem estar atentos a fim de garantir que o computador seja utilizado de forma responsável, com potencialidades pedagógicas realmente verdadeiras e não apenas como máquinas que possuem programas divertidos e agradáveis [Vieira00].

A utilização do computador de forma criativa como recurso psicopedagógico, a partir de programas e ambientes interativos, na solução de problemas de aprendizagem é estudada por Vasconcelos [Vasconcelos98]. Ele ressalta sua importância na organização do conhecimento pela criança, propiciando maior compreensão da função social da escrita, maior disposição ao enfrentar o erro e maior cooperação grupal. Mas, para isto, não basta que o professor saiba "como mexer no computador" e lidar com softwares, mas, sim, que compreenda quais são as vantagens de sua utilização para a organização do pensamento e a sociabilização da criança [Pinto99]. Também é importante que a escola se conscientize de que a Informática não pode ficar restrita a um "responsável pelo laboratório", mas faça parte de todas as disciplinas, numa abordagem interdisciplinar [Lopes98].

Em se tratando da Matemática, ensiná-la tem sido uma tarefa difícil. Machado [Machado87] conclui, através de uma reflexão mais profunda, que a dificuldade não está na Matemática em si, mas em como vem sendo ensinada, passando-se a imagem de que 
ela é o lugar por excelência das abstrações, enfatizando-se seus aspectos formais, num total divórcio da realidade e de seu significado, tanto para quem aprende como para quem ensina. No ponto de vista de Itacarambi [Gladcheffoof], "o primeiro passo é que o aluno "olhe" a Matemática como algo considerado moderno; este aluno está acostumado com a tecnologia, como por exemplo, a televisão e o telefone, e é preciso que a sala de aula se utilize da tecnologia que lhe for adequada". E complementa "... a Matemática é o subsídio de todo o conhecimento ligado à Informática e à tecnologia, e o professor pode tirar proveito disto".

Hoje em dia, a preocupação já não é tanto com a introdução ou não do computador na educação e sim com as vantagens e perigos que proporciona, o desenvolvimento de metodologias, o papel do professor, aspectos técnicos, pedagógicos, psicológicos, políticos e sociológicos ligados ao computador e, também, com a avaliação de ferramentas computacionais, utilizando critérios [Giraffa00]. Seja qual for o objeto escolhido para sua aula, é necessário que o professor defina objetivos e domine aquilo que propõe [Viana00]. Com o software não é diferente e o professor deve estar atento para $\circ$ fato de que o uso desta ferramenta computacional exige ainda mais dos educadores. Portanto, é necessária uma análise criteriosa que permita, antes, a escolha e, depois, a mais adequada utilização [Saraiva98].

A preocupação com a qualidade dos softwares educacionais é destacada, inclusive, pelo governo federal. Segundo o MEC [MEC00], no dia 30 de junho de 2000, o comitê gestor responsável pela execução do projeto "Red Internacional Virtual de Educación (Rived)" realizou, em Brasília, sua primeira reunião de trabalho. O projeto reúne Brasil, Colômbia, Venezuela, Panamá e Peru, e aborda a produção de software para apoiar o ensino de Ciências e Matemática na escola pública. O objetivo desta reunião, com a 
participação de representantes dos cinco países, foi definir o regulamento interno, a política de utilização de recursos, direitos autorais e procedimentos para desenvolvimento e controle de qualidade dos produtos.

Neste trabalho investigamos como avaliar a qualidade de um produto de software educacional a ser utilizado no ensino de Matemática, nas séries do Ensino Fundamental.

Alguns trabalhos encontrados nessa mesma linha (Avaliação da Qualidade de Software Educacional), não apresentam enfoque tão específico. Abrangem de forma genérica as diversas aplicações dos produtos de software existentes, sem se atentarem, de forma específica, às várias áreas (exatas, biológicas ou humanas) ou às particularidades quanto à faixa etária (infantil, juvenil ou adulto) a quem os produtos se destinam. Tais trabalhos são relacionados na Seção 3.5 deste documento.

Mesmo empregando-se técnicas sofisticadas de Engenharia de Software, o desenvolvimento de software, pode resultar em produtos com problemas de qualidade. De forma simplificada pode-se dizer que estes problemas, na visão de um usuário, situam-se em uma das duas categorias seguintes: falhas na qualidade de conformidade (que diz respeito à aderência do produto à finalidade para a qual foi construído) e falhas na qualidade de desempenho (que se refere à capacidade do produto em apresentar consistentemente a funcionalidade desejada, ou seja, bom desempenho, ausência de bugs, tolerância a erros do usuário, etc.) [Belloquim97]. É importante destacar, também, problemas de qualidade do ponto de vista da manutenibilidade e adaptabilidade do produto a novos requisitos. Desta forma, o controle de qualidade surge como uma necessidade e a avaliação e o julgamento da qualidade do software tornam-se muito úteis. 
Avaliação da Qualidade de Software é o processo técnico de medição da qualidade e pode envolver [Andrade96]:

- Avaliação do Processo de Desenvolvimento de Software, que consiste no exame dos procedimentos operacionais e gerenciais, métodos e técnicas utilizados nas fases de desenvolvimento de um produto de software, com o objetivo de identificar práticas que possam provocar problemas na qualidade do produto e de estabelecer novas práticas que evitem estes problemas; e,

- Avaliação do Produto de Software, que consiste no exame de um produto final resultante de um Processo de Desenvolvimento de Software, ou de produtos resultantes de atividades de fases intermediárias deste processo.

Os dois tipos de avaliação são necessários e complementares e, embora distintos, com técnicas e métodos específicos, objetivam garantir a qualidade do produto final.

A relação entre Qualidade de Processo e Produto pode ser examinada nos seguintes aspectos [Tsukumo95]:

- como os requisitos da Qualidade do Produto, que definem os níveis mínimos de aceitação do produto para a finalidade a que se destina, podem orientar o Processo;

- como os documentos gerados durante o Processo podem fornecer evidências da própria Qualidade do Produto;

- como a avaliação de Produtos Intermediários e Finais deve realimentar o Processo;

- como as atividades de desenvolvimento podem ser alteradas para permitir avaliações de Produtos Intermediários.

A avaliação da qualidade é importante para o produtor de software tanto durante o processo de desenvolvimento quanto com o produto já lançado. Ele pode avaliar produtos intermediários para assegurar qualidade do produto final e corrigir aspectos negativos 
antes da liberação do produto. Com estes procedimentos o produto pode ser liberado para distribuição com melhor nível de qualidade. E, com o produto já lançado, pode avaliá-lo para planejar ações corretivas e evolutivas. Para o comprador, a avaliação pode ajudar na seleção do produto mais adequado para as suas necessidades. Para o usuário, a avaliação pode ajudá-lo a ter maior confiança no produto que está usando. Também o vendedor pode usar informação sobre a qualidade do produto como argumento de venda.

A utilização de softwares com qualidade "comprovada" aumenta a segurança de pessoas e a disponibilidade de serviços essenciais à população [CTI97]. De fato, empresas que desenvolvem softwares com qualidade são mais competitivas, o que é muito importante para a sobrevivência das mesmas em um mercado cada vez mais globalizado. Da mesma forma, as empresas que consomem software de alta qualidade têm chances maiores de manter e conquistar mercados. Mas a garantia de qualidade do software, em muitos casos, não é dada pelo produtor ao usuário, que nem sempre a exige ou mesmo sabe como exigi-la. Em grande parte, isto ocorre porque é difícil avaliar a qualidade de um software. Particularmente, em se tratando de softwares educacionais, este fato é preocupante, pois a utilização de software de alta qualidade deve proporcionar ao educador a segurança de estar transmitindo conhecimento com uma ferramenta adequada a seus alunos, explorando, assim, possibilidades que a Informática oferece para facilitar a aprendizagem e enriquecer seu trabalho, de forma correta e eficiente. As escolas, em especial os professores, precisam conhecer aspectos envolvidos na avaliação de software educacional, para que possam avaliar criticamente os produtos a serem adquiridos e utilizados [Campos99a]. No contexto educacional os alunos podem não ser os responsáveis pela seleção de um produto a ser utilizado, mas, certamente, serão os que mais sofrerão com um software de baixa qualidade ou não adequado à sua realidade. 


\section{I.I OBJETIVOS}

Dentro do contexto atual no ambiente educacional, onde o emprego da Informática é cada vez mais freqüente, temos, como conseqüência, o aumento do número e variedade de softwares educacionais disponíveis no mercado. Estes, por sua vez, se propõem a contribuir com o processo de ensino-aprendizagem. Faz-se necessário, como em relação a qualquer outra ferramenta, que os softwares sejam analisados antes de serem efetivamente utilizados no processo.

Avaliação de software educacional é uma área de trabalho bastante complexa por envolver diversas disciplinas. Não se pode avaliar um software educacional apenas com base em suas características de qualidade técnicas (funcionalidade, usabilidade, confiabilidade, eficiência, manutenibilidade, portabilidade). Deve-se, também, levar em conta os aspectos educacionais envolvidos, ou seja, aspectos pedagógicos, psicopedagógicos, socioculturais, cognitivos e lúdicos. Entende-se, neste contexto, como aspectos:

- PEDAGÓGICOS: programas de ensino, objetivos, formas de avaliação, ...;

- COGNITIVOS: forma de aquisição do conhecimento, a maneira com que o conhecimento é guardado na memória;

- PSICOPEDAGÓGICOS: motivação, individualização da aprendizagem, ...;

- LúDicos: referentes a, ou que tem o caráter de jogos, brinquedos e divertimentos. $\mathrm{O}$ aprender brincando;

- SOCIOCULTURAIS: oportunidade de uso do computador, intercâmbio cultural, relativos à cultura da criança, ...

Nosso objetivo é contribuir nesse sentido, propondo um instrumento de avaliação na forma de questionários, baseando-nos tanto em aspectos técnicos como em conceitos e 
princípios de qualidade de software ligados à educação. Para isto, contamos com o envolvimento de especialistas da área educacional (professores, pedagogos e uma psicopedagoga) através da obtenção de conhecimentos, obtidos por meio de uma técnica de aquisição de conhecimento explícito ${ }^{1}$. Procuramos neste instrumento/questionário envolver isoladamente produtos de software direcionados ao aprendizado de Matemática para alunos "apenas" do Ensino Fundamental. Com esta delimitação, reduzimos as variáveis relacionadas aos aspectos educacionais dos elementos envolvidos (especialista em Informática, professor, aluno), possibilitando um trabalho com mais qualidade e precisão em seus questionamentos. Procuramos, também, enfocar aspectos específicos para diferentes tipos de softwares educacionais (tutorial, exercício e prática, jogo pedagógico, simulação e sistema hipermídia).

A utilização do instrumento possibilitará a avaliação de produtos de software educacional, a fim de que seja reconhecido o quão aplicável este produto pode ser, dentro dos objetivos traçados pelo professor, de forma a agregar valor ao ambiente de ensinoaprendizagem de Matemática no Ensino Fundamental.

O instrumento gerado neste trabalho não é, necessariamente, dirigido a professores, uma vez que podemos ter, também, como prováveis consumidores e, portanto, interpretadores da avaliação, outros elementos como pedagogos, administradores escolares ou mesmo pais. Mas esperamos que seja mais efetivo numa classificação sob a ótica dos "professores de Matemática", tendo em vista vários questionamentos que são abordados (conceitos ligados à área educacional), dificultando um pleno entendimento por parte de um público menos especializado.

\footnotetext{
1 Entende-se por "conhecimento explícito" toda e qualquer informação necessária para diferenciar e caracterizar o objeto de pesquisa (neste trabalho, software educacional).
} 


\section{I.II ORganização da DissertaçÃo}

O Capítulo 2 aborda definições e requisitos de qualidade. A Seção 2.1 trata da qualidade de software, enfocando iniciativas existentes na literatura em relação à avaliação do processo de desenvolvimento do software. Já conceitos relacionados à qualidade do produto de software, descritos na Norma ISO/IEC 9126-1, assim como aspectos relacionados a sua avaliação, são tratados na Seção 2.1.1. No contexto deste trabalho a característica "usabilidade" possui uma importância ainda maior por se tratar de softwares que poderão ser utilizados em um ambiente de ensino-aprendizagem para crianças que possuem, em média, de 7 a 14 anos de idade. Sendo assim, esta característica é melhor detalhada na Seção 2.1.2.

O Capítulo 3 discorre sobre a Informática na educação, apresentando na Seção 3.1 as tendências identificadas na tradição pedagógica brasileira e na Seção 3.1.1 os novos rumos da educação. A Seção 3.2 relata um histórico da Matemática no Ensino Fundamental durante o século XX. A Informática educativa no Ensino Fundamental como um todo e mais especificamente no de Matemática é tratada nas seções 3.3 e 3.3 .1 respectivamente. Na Seção 3.4 são descritas as diferentes modalidades do software educacional e na Seção 3.5 é abordada a avaliação da qualidade do software educacional. Dentro das diferentes modalidades existentes, na Seção 3.6 tratamos das modalidades de software educacional contempladas no instrumento de avaliação gerado. Uma indicação sobre a produção de software educacional de Matemática no Brasil é dada na Seção 3.7.

O Capítulo 4 descreve a metodologia de pesquisa utilizada neste trabalho. A abordagem GQM, a técnica entrevista e o método da avaliação heurística são descritos, 
respectivamente, nas seções $4.1,4.2$ e 4.3 .

No Capítulo 5 é feito um relato sobre o desenvolvimento do trabalho, enfatizando na Seção 5.1 a primeira utilização do método GQM, na Seção 5.2 a segunda utilização e, na Seção 5.3, a terceira.

O Capítulo 6 apresenta os questionários juntamente com os procedimentos elaborados para a avaliação do produto de software educacional de Matemática, direcionado ao Ensino Fundamental, assim como para a elaboração de um relatório. Sendo assim, a Seção 6.1 trata dos procedimentos de avaliação; a Seção 6.2 apresenta os questionários da avaliação geral do produto; a Seção 6.3 apresenta o questionário elaborado especificamente para avaliar a usabilidade do produto, contando com a participação de alunos. Se o professor desejar elaborar um relatório sobre o software avaliado, a Seção 6.4 traz como sugestão uma forma de fazê-lo.

O Capítulo 7 corresponde às conclusões da dissertação. São apresentadas observações quanto à importância e aplicabilidade deste trabalho, assim como sugestões para trabalhos futuros.

Por fim, são apresentadas as referências bibliográficas no Capítulo 8.

Um glossário com os termos técnicos utilizados nos questionamentos do instrumento gerado com este trabalho, é apresentado no Apêndice $A$ e, uma relação de materiais adicionais, disponíveis na $W e b$, referentes a este projeto de mestrado, é colocada como Apêndice B. 


\section{Capítulo 2}

\section{QuALIDADE}

No começo do século XX, da década de 20 até o final da Segunda Guerra Mundial, qualidade era definida pelo controle do produto final, ou seja, significava apenas assegurar que o produto defeituoso não chegasse ao usuário. Na década de 60 , qualidade passou a ser designada através do controle de todas as etapas de produção do produto. Já na década de 70 , normas e procedimentos formais começaram a surgir com o intuito de garantia da qualidade e, hoje, o conceito de qualidade está envolvido com a qualidade total no sentido de satisfação do usuário ou cliente e competitividade [Tsukumo96].

A Norma ISO/IEC 8402 [ISO8402] define Qualidade como "a totalidade das características de uma entidade que Ihe confere a capacidade de satisfazer necessidades explícitas e implícitas". Em geral, as necessidades explícitas são expressas na definição de requisitos propostos pelo produtor e as necessidades implícitas são aquelas que podem não estar expressas nos documentos do produtor, mas que são necessárias ao usuário.

Os Requisitos de Qualidade do Produto expressam o Modelo de Qualidade de forma concreta e particularizada para um determinado produto. Definem o conjunto de necessidades explícitas e implícitas assim como os níveis mínimos para sua aprovação, de acordo com a finalidade a que se destina [Tsukumo97]. Os requisitos podem ser classificados como: 
- necessários (quando o não atendimento gera insatisfação e o atendimento, indiferença);

- unidimensionais (se há insatisfação pelo não atendimento e satisfação pelo atendimento);

- atrativos (se provocam sentimento de satisfação quando atendidos, mas de indiferença se não forem atendidos).

Deve-se notar que a aplicação dessa classificação é dinâmica, sofrendo variações conforme o amadurecimento do mercado. Por exemplo, interfaces gráficas que eram há alguns anos atrativas, hoje, para certos tipos de software, são consideradas necessárias. Essa análise pode ser ilustrada através de gráficos colocando-se o "atendimento ao requisito" em um eixo e o "sentimento de satisfação do usuário" no outro, obtendo-se o diagrama da Figura 2.1.

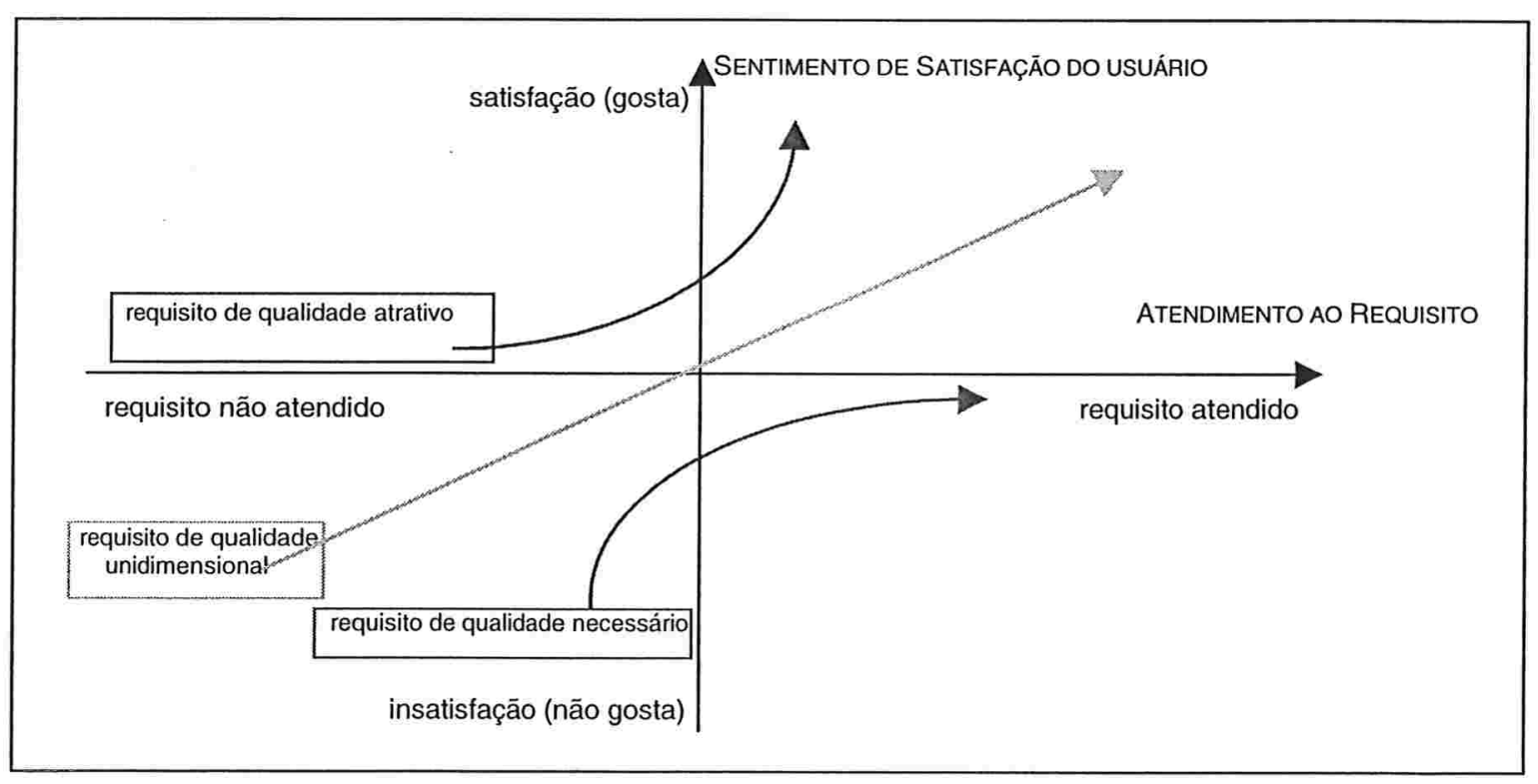

Figura 2.1 - Análise dos requisitos de qualidade [Tsukumo97] 
As necessidades explícitas podem ser relacionadas a partir dos documentos de especificação de requisitos e manual do usuário. Já o levantamento das necessidades implícitas envolve atividades como:

- análise de mercado e dos produtos concorrentes para identificar tendências para o tipo de produto;

- análise de documentos de assistência a usuários tais como, registros de reclamações, consultas e sugestões;

- análise junto a usuários potenciais e especialistas na área de aplicação;

- análise ética, procurando estabelecer conseqüências da utilização do produto e da sua falha não apenas nos personagens diretamente envolvidos mas, também, naqueles que possam ser afetados direta ou indiretamente [Collins94] [Tsukumo97].

\section{II.I QualidADE DE SOFTWARE}

Do ponto de vista dos desenvolvedores de software, qualidade não é mais um fator de vantagem no mercado, mas uma condição necessária para que a organização possa continuar competindo com sucesso. Dos requisitos do cliente à entrega do produto final, existe um processo de desenvolvimento que é complexo e, freqüentemente, envolve uma série de estágios que influenciam a qualidade do produto final. Um processo bem estabelecido, compreendido e controlado, pode ajudar a alcançar a obtenção de qualidade, desde que sejam definidos claramente os requisitos de qualidade do produto [Paulk93].

Como é intensa a dinâmica que rege o processo de software, gerenciá-lo torna-se uma tarefa difícil. Para tanto, descrever e definir um modelo de processo de software se 
faz necessário, podendo-se utilizar métodos de modelagem adequados [Oliveira95]. Para controlar esta dinâmica, alguns modelos de processos de software são propostos na literatura, como por exemplo: o SW-CMM (Capability Maturity Model), que é um modelo proposto pelo Software Engineering Institute (SEI) para o Departamento de Defesa dos EUA, que avalia e propõe melhoria para a capacidade do processo de software de uma organização para produzir um produto com qualidade [Paulk93]; o Software Process Improvement and Capability dEtermination (SPICE), que é um projeto em âmbito mundial promovido pela ISO/IEC ${ }^{2}$ que se preocupa em padronizar internacionalmente os conceitos de qualidade de processos de software e que propõe, também, melhoria contínua deste processo [Rout95] (o resultado deste projeto foi transformado em Norma em 1998 Norma ISO/IEC 15504); a Norma ISO 9000-3 [ISO9000-3] que é um guia de aplicação da ISO 9001 [ISO9001] para o desenvolvimento, fornecimento e manutenção de software ( a Norma ISO 9001 faz parte da série de normas ISO 9000, voltadas para a gestão e garantia da qualidade).

Com modelos, procura-se melhorar o processo de produção para se adquirir maior confiança na qualidade do produto final. No entanto, o controle para a garantia da qualidade pode ser feito em duas circunstâncias: durante a geração do software e após ele estar pronto para uso. Na primeira, procura-se avaliar de que forma o software está sendo desenvolvido, identificando práticas que possam conduzir a problemas na qualidade do produto e desenvolvendo práticas que evitem estes problemas. Na segunda, com o produto liberado, procura-se avaliar a sua qualidade a fim de identificar deficiências e limitações em sua aplicabilidade [Tsukumo96].

\footnotetext{
2 ISO - International Organization for Standardization. IEC - International Electrotechnical Commission.
} 
Neste trabalho, o enfoque está restrito à avaliação da qualidade do produto de software, ou seja, após estar ele liberado para uso.

\section{II.I.I Qualidade de Produto de Software}

Um Produto de Software é definido pela norma ISO/IEC 9126-1 [ISO9126-1] como "uma entidade de software disponível para liberação a um usuário" e, Qualidade de Software é definida como " a totalidade das características de um produto de software que Ihe confere a capacidade de satisfazer necessidades explícitas e implícitas" (conceitos já citados anteriormente).

Uma versão nacional da Norma ISO/IEC 9126 foi publicada em 1996, pela ABNT², como NBR 13596 [NBR13596]. Neste trabalho, optamos pela utilização direta da série de Normas ISO/IEC 9126.

A Norma ISO/IEC 9126-1, publicada em 1991 como ISO/IEC 9126, estabeleceu um conjunto de seis características de qualidade de produto de software, ou seja, um conjunto de atributos pelos quais sua qualidade pode ser descrita e avaliada. São elas: Funcionalidade, Usabilidade, Confiabilidade, Eficiência, Manutenibilidade e Portabilidade. A Tabela 2.1.1.1 mostra as características da Qualidade de Software segundo a ISO/IEC 9126-1 e a Tabela 2.1.1.2 mostra as subcaracterísticas. As Normas ISO/IEC 9126-2 [ISO9126-2] e ISO/IEC 9126-3 [ISO9126-3] fazem parte da série de Normas da ISO/IEC 9126 e tratam de métricas externas e internas do produto de software, respectivamente.

\footnotetext{
${ }^{3}$ ABNT - Associação Brasileira de Normas Técnicas.
} 


\begin{tabular}{||l|l||}
\hline Funcionalidade & $\begin{array}{l}\text { Evidencia que o conjunto de funções atende às necessidades explícitas e implícitas } \\
\text { para a finalidade a que se destina o produto. }\end{array}$ \\
\hline Usabilidade & Evidencia a facilidade de utilização do software. \\
\hline Confiabilidade & $\begin{array}{l}\text { Evidencia que o desempenho se mantém ao longo do tempo em condições } \\
\text { estabelecidas. }\end{array}$ \\
\hline Eficiência & $\begin{array}{l}\text { Evidencia que os recursos e os tempos envolvidos são compatíveis com o nível de } \\
\text { desempenho requerido para o produto. }\end{array}$ \\
\hline Manutenibilidade & Evidencia que há facilidade para correções, atualizações e alterações. \\
\hline Portabilidade & $\begin{array}{l}\text { Evidencia que é possivel utilizar o produto em diversas plataformas com pequeno } \\
\text { esforço de adaptação. }\end{array}$ \\
\hline
\end{tabular}

TABELA 2.1.1.1 - CARACTERÍSTICAS DA QUALIDADE DE SOFTWARE SEGUNDO A ISO/IEC 9126-1 [TSUKUMO97]

Essa Norma é o resultado de um esforço da ISO/IEC em que se procurou cobrir todos os aspectos da qualidade de software, com um mínimo de sobreposição e aproveitando conceitos presentes em modelos apresentados desde 1977, por McCall [McCall77], Boehm [Boehm81], até os mais recentes, como o modelo FURPS da Hewlett Packard [Pressman97].

As seis características constituem um Modelo de Qualidade de Software genérico. Este modelo deve ser particularizado para cada produto, conforme sua categoria, objetivos e riscos de utilização. Subcaracterísticas devem ser selecionadas visto que algumas podem não ser necessárias dependendo do tipo do produto de software a ser avaliado e o peso dado a cada uma delas deve ser diferenciado. 


\begin{tabular}{|c|c|c|}
\hline \multirow{5}{*}{ Funcionalidade } & Adequação. & $\begin{array}{l}\text { Presença de conjunto de funções e sua apropriação para } \\
\text { as tarefas. }\end{array}$ \\
\hline & Acurácia. & Geração de resultados ou efeitos corretos. \\
\hline & Interoperabilidade. & Capacidade de interagir com outros sistemas. \\
\hline & Conformidade. & $\begin{array}{l}\text { Estar de acordo com normas, convenções, } \\
\text { regulamentações. }\end{array}$ \\
\hline & Segurança de Acesso. & $\begin{array}{l}\text { Capacidade de evitar acesso não autorizado a programas } \\
\text { e dados. }\end{array}$ \\
\hline \multirow{3}{*}{ Usabilidade } & Inteligibilidade. & $\begin{array}{l}\text { Facilidade de reconhecimento do conceito lógico e sua } \\
\text { aplicabilidade. }\end{array}$ \\
\hline & Apreensibilidade. & Facilidade de aprendizado. \\
\hline & Operacionalidade. & Facilidade de operação e controle. \\
\hline \multirow{3}{*}{ Confiabilidade } & Maturidade. & Freqüência de falhas. \\
\hline & Tolerância a falhas. & Manter nível de desempenho em caso de falha. \\
\hline & Recuperabilidade. & $\begin{array}{l}\text { Capacidade de se restabelecer e restaurar dados após } \\
\text { falha. }\end{array}$ \\
\hline \multirow{2}{*}{ Eficiência } & $\begin{array}{l}\text { Comportamento em } \\
\text { relação ao tempo. }\end{array}$ & Tempo de resposta, de processamento. \\
\hline & $\begin{array}{l}\text { Comportamento em } \\
\text { relação a recursos. }\end{array}$ & Quantidade de recursos utilizados. \\
\hline \multirow{4}{*}{ Manutenibilidade } & Analisabilidade. & Facilidade de diagnosticar deficiências e causas de falhas. \\
\hline & Modificabilidade. & Facilidade de modificação e remoção de defeitos. \\
\hline & Estabilidade. & Ausência de riscos de efeitos inesperados. \\
\hline & Testabilidade. & Facilidade de ser testado. \\
\hline \multirow{4}{*}{ Portabilidade } & Adaptabilidade. & Capacidade de ser adaptado a ambientes diferentes. \\
\hline & $\begin{array}{l}\text { Capacidade para ser } \\
\text { instalado. }\end{array}$ & Facilidade de instalação. \\
\hline & Conformidade. & Acordo com padrões ou convenções de portabilidade. \\
\hline & $\begin{array}{l}\text { Capacidade para } \\
\text { substituir. }\end{array}$ & Substituir outro software. \\
\hline
\end{tabular}

TABELA 2.1.1.2 - SUBCARACTERISTICAS DA QUALIDADE DE SOFTWARE SEGUNDO A ISO/IEC 9126-1 [TSUKUMO97]

As características formam uma base para que se verifique "o quê" o sistema faz e "como" funciona. Cada uma delas busca um conjunto de atributos cuja evidência de existência o avaliador deve identificar, tornando possível a validação e verificação do 
sistema. Através da validação, assegura-se que o sistema corresponde ao desejado, ou seja, que está em conformidade com os requisitos do sistema e, na verificação, é assegurado que o software implementa corretamente cada funcionalidade do sistema.

A série ISO/IEC 14598 complementa a série ISO/IEC 9126 e permite uma avaliação padronizada das características de qualidade de um software. A Norma ISO/IEC 14598-1 [ISO14598-1] dá uma visão geral da estruturação desta série de Normas e dos processos de avaliação; a Norma ISO/IEC 14598-2 [ISO14598-2] apresenta as atividades de planejamento e gerenciamento do processo de avaliação; a Norma ISO/IEC 14598-3 [ISO14598-3], as atividades de avaliação durante o processo de desenvolvimento do software; a Norma ISO/IEC 14598-4 [ISO14598-4], as atividades de avaliação no processo de seleção para aquisição do software; a Norma ISO/IEC 14598-5 [ISO145985], apresenta um ciclo de vida de avaliação, com definição das atividades, incluindo relações entre avaliador e requisitante; e, a Norma ISO/IEC 14598-6 [ISO14598-6] define a estrutura de módulos de avaliação.

A Norma ISO/IEC 12119 [ISO12119] foi desenvolvida com o objetivo de ajudar e orientar o usuário na avaliação de pacotes de software, também conhecidos como "software de prateleira". Além de estabelecer os requisitos de qualidade para este tipo de software, ela também destaca a necessidade de instruções para teste deste pacote, considerando tais requisitos. Esta Norma também possui um versão nacional, publicada pela ABNT, como NBR 12119 [NBR12119] (Também, aqui, optamos pela utilização direta da Norma ISO/IEC 12119).

Com o conhecimento das necessidades explícitas e implícitas, pode-se pensar na avaliação da qualidade de um produto de software centrado no interesse do usuário, o 
que significa medir a "qualidade em uso, ou seja, o grau em que o produto pode ser usado por usuários específicos para alcançar objetivos especificados com eficácia, eficiência e satisfação num contexto particular de uso" [ISO14598-1]. Um dos problemas primários de qualidade é que um pedaço do software pode estar em conformidade com seus requisitos, mas quando é colocado "em uso", o usuário constata que aquelas funções não são suficientes para tornar o software útil [Freeman87] [Tsukumo97].

A "qualidade em uso" pode ser medida através de pesquisas de opinião entre usuários utilizando técnicas como: entrevistas pessoais face-a-face, entrevistas realizadas por telefone e questionários via correio [Kan95]. Outra forma é através de um procedimento de avaliação em que se simulam as condições normais de operação do produto e se emitem juízos sobre os atributos do produto em resposta a questionários. A avaliação da qualidade em uso tem a vantagem de examinar o produto como um todo e na condição de uso. No entanto, pode se tornar pouco profunda e muito influenciada pela subjetividade do avaliador.

Geralmente defendida por pessoas envolvidas com métricas de software, outra forma de avaliação de produto assume que, medindo e controlando propriedades internas (indicadores internos de qualidade), seu comportamento externo será melhorado. As medições internas são normalmente feitas em produtos intermediários, através de técnicas como leitura, inspeção e análise estática automatizada, resultando em medidas específicas para determinados atributos. As medições externas são feitas com o produto em operação, através de testes e técnicas específicas para os atributos a serem investigados ${ }^{4}$

\footnotetext{
${ }^{4} \mathrm{Na}$ literatura, o tema "métricas de software" pode ser encontrado em [Ince90], [Pressman97] e [Shepperd92].
} 
Para se determinar uma avaliação consistente, as diversas medidas devem ser correlacionadas e mutuamente validadas. Neste sentido, a abordagem GQM (descrita na Seção 4.1), proposta por Victor Basili [Basili94], é uma alternativa. A aplicação do GQM, enfocada nas características de qualidade de software definidas pela ISO/IEC 9126-1, pode resultar numa estrutura de medições, constituindo um roteiro para avaliação da qualidade de produto de software.

O paradigma GQM tem sido proposto como uma abordagem orientada a objetivos para a avaliação de produtos e processos na Engenharia de Software. As medições dos objetivos, explicitamente definidos, são refinados em um conjunto de questões, as quais representam uma definição operacional do objetivo, como por exemplo: "como é a distribuição de falhas por variedade?". Para cada questão as métricas relevantes são definidas, tais como: "número total de falhas" ou "número das principais falhas".

Os softwares podem ser classificados em diversas categorias: sistemas de engenharia e ferramentas gráficas, sistemas de informação, sistemas de suporte à documentação e ao planejamento, educação, entretenimento, etc. De acordo com a categoria do produto a ser avaliado, as características ressaltadas devem ser avaliadas com uma maior profundidade utilizando-se diferentes métodos.

Em se tratando de softwares educacionais, como dito no Capítulo 1, é preciso que sejam levados em conta, também, aspectos ligados à educação. Esta categoria é discutida no Capítulo 3. 


\section{II.I.II A Característica de Qualidade Usabilidade}

O termo interface, desde o seu surgimento, era aplicado ao "hardware e software com o qual homem e computador podiam se comunicar". Mas com a evolução deste conceito, aspectos cognitivos e emocionais do usuário, durante a comunicação, começaram a ser levados em consideração [Rocha00].

Segundo Laurel [Laurel93] [Rocha00], uma definição de base para o termo "interface" pode ser: uma superfície de contato que reflete as propriedades físicas das partes que interagem, as funções a serem executadas e o balanço entre poder e controle. Os termos "poder e controle", colocados nesta definição, refletem o fato de que usuários que percebem possuir um alto grau de controle sobre os computadores têm atitudes positivas com relação a eles [Kay89] [Rocha00]. Assim sendo, não se pode pensar em interface sem levar em conta o ser humano que irá utilizá-la e, portanto, este termo não pode ser estabelecido ou analisado independente do termo interação.

Já, para Andersen [Andersen97] [Rocha00], um pesquisador na área de semiótica computacional $^{5}$, interface significa "uma coleção de signos baseados no computador, ou seja, uma coleção das partes do software que podem ser vistas ou ouvidas, usadas e interpretadas por uma comunidade de usuários".

Do ponto de vista do usuário, a interface é o que, por exemplo, torna um piloto capaz de pilotar um moderno avião ou mesmo torna possível a expansão de horizontes

\footnotetext{
${ }^{5}$ A semiótica, a arte dos sinais, é a denominação utilizada para a ciência geral do signo; semiologia. Objetiva estudar os signos e sistemas de signos, onde um signo significa qualquer coisa que está no lugar de outra sob determinados aspectos ou capacidades, para alguém, ou seja, qualquer marca, símbolo, sinal, etc. usado para indicar e "transportar" pensamentos, informações e comandos [Rocha00]. Assim, a "semiótica computacional" é uma proposta de Andersen para uma aplicaçäo da semiótica não apenas ao projeto de interfaces, mas, também, à programação, análise e projeto de software.
} 
de crianças em ambiente de aprendizagem. Dentro deste contexto, produzir sistemas usáveis, seguros e funcionais, são os objetivos a serem buscados pela interação/interface usuário-computador [Pressman97]. Nielsen [Nielsen93] engloba estes objetivos em um conceito mais amplo denominado Aceitabilidade de um Sistema que, por sua vez, é a combinação das aceitabilidades social e prática. Estes atributos de aceitabilidade de sistemas podem ser observados na Figura 2.1.2.1.

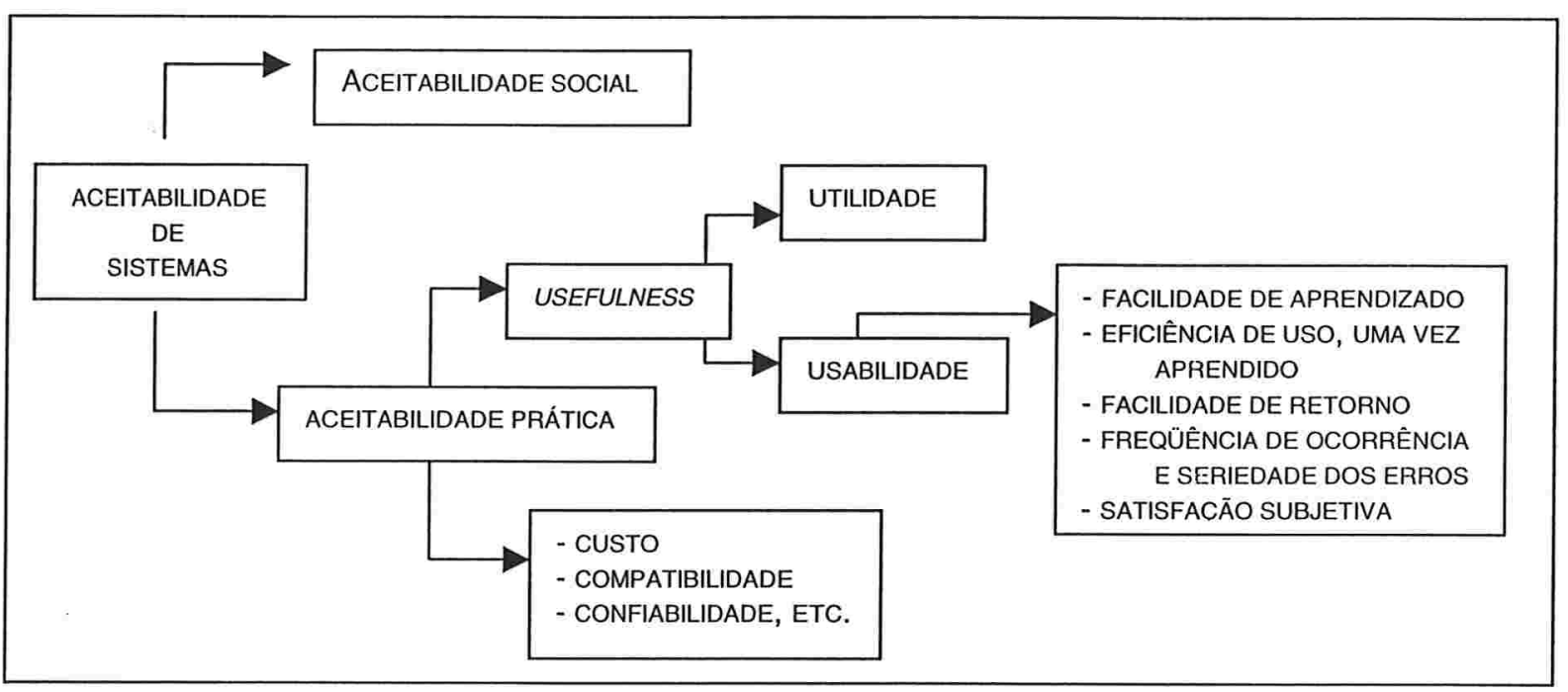

Figura 2.1.2.1 - ATRIBUTOS DE ACEITABILIDADE DE SISTEMAS [ROCHA00, PP.18]

A caraterística "usabilidade", que é a questão relacionada a quão bem os usuários podem usar a funcionalidade definida pelo sistema, é uma parte da categoria "usefulness", que se refere ao sistema poder ser usado para atingir um determinado objetivo. Esta característica, levando em consideração aspectos cognitivos e emocionais do usuário, pode ser definida em função de múltiplos componentes e é, segundo Nielsen [Nielsen93], tradicionalmente associada a cinco atributos: 
1. Facilidade de aprendizado

O uso do sistema deve ser fácil de aprender, de forma que o usuário possa começar a interagir rapidamente.

2. Eficiência de uso, uma vez aprendido

Uma vez que o usuário aprendeu a utilizar o sistema, é preciso que tenha um elevado nível de produtividade.

3. Facilidade de retorno

É preciso que o usuário, ao voltar a usar o sistema após um certo tempo, lembre-se facilmente de como deve utilizá-lo.

\section{Freqüência de ocorrência e seriedade dos erros}

O erro, neste contexto, é definido como uma ação do usuário que não leva ao resultado esperado. É preciso que o sistema não leve o usuário a cometer muitos erros durante, sua utilização.

\section{Satisfação subjetiva}

Neste atributo é verificado o quão agradável de usar é o sistema. Este deve ser agradável, de forma que o usuário fique satisfeito ao utilizá-lo.

Como pode ser notado, a Tabela 2.1.1.2 (Seção 2.1.1), que contém as subcaracterísticas da Qualidade de Software segundo a Norma ISO/IEC 9126-1, não engloba diretamente aspectos cognitivos e emocionais do usuário, quando trata da característica usabilidade. Já os atributos associados a mesma caraterística, indicados por Nielsen [Nielsen93], os englobam.

No contexto deste trabalho, a característica "usabilidade" possui uma importância ainda maior por se tratar de softwares que poderão ser utilizados em um ambiente de ensino-aprendizagem para crianças que possuem, em média, de 7 a 14 anos de idade. 
Em softwares deste tipo, ou seja, softwares educacionais, os atributos mais importantes a serem considerados podem ser:

- facilidade de aprendizado, pois é preciso que o software se comporte apenas como um instrumento ou uma ferramenta a ser aplicada no processo ensinoaprendizagem. Se este exigir do aluno muito tempo para que possa manipulá-lo, o intuito central de sua utilização será prejudicado;

- facilidade de retorno, ou seja, caso o software seja utilizado em aulas com um certo intervalo de tempo, é preciso que o aluno, ao voltar a usá-lo, lembre-se, facilmente, de como fazê-lo;

- freqüência de ocorrência de seriedade dos erros, pois é preciso que o software impossibilite o aluno de cometer muitos erros ao utilizá-lo e, caso o erro seja cometido, deve ser possível recuperá-lo facilmente;

- satisfação subjetiva, ou seja, o software deve ser agradável a fim de que o aluno fique satisfeito e motivado a utilizá-lo.

Como coloca Campos [Campos99b], a usabilidade é a característica específica mais importante no software educacional e, considerando os atributos citados, é possível compreender que a questão da usabilidade da interface do software precisa ser avaliada não apenas pelo professor, mas sim, e talvez, principalmente, pelos alunos. Muitas vezes o que parece natural ao professor, para a criança pode não ter significado algum, ou até mesmo, o professor pode gostar muito de um software e acreditar que a ferramenta que está sendo avaliada possa despertar interesse e motivação por parte das crianças, mas no momento em que a utiliza em sala de aula, percebe que os alunos não se entusiasmaram [Giraffa00]. 
Desta forma, propomos que a avaliação da usabilidade da interface do software seja realizada também por alguns alunos, sendo dirigida pelo professor antes mesmo de decidir utilizá-lo em suas aulas e após ter completado sua própria avaliação.

Uma "inspeção de usabilidade" é definida para um conjunto de métodos baseados em se ter avaliadores inspecionando ou examinando aspectos relacionados à usabilidade de uma interface de usuário. Segundo Rocha [Rocha00], alguns dos métodos são:

- Avaliação Heurística: a inspeção da usabilidade é feita tendo como base uma pequena lista de heurísticas de usabilidade;

- Revisão de Guidelines: a interface é analisada no sentido de verificar se está de acordo com uma lista de usabilidade, que geralmente contém uma seqüência de cerca de mil diretrizes;

- Percurso Cognitivo: o avaliador simula o usuário "caminhando" na interface para executar tarefas típicas. Este método foi desenvolvido para interfaces que podem ser aprendidas de forma explanatória, mas, também, são úteis em interfaces que exigem muito treinamento.

Os avaliadores podem ser especialistas em usabilidade, especialistas em um determinado padrão de interface, usuários finais, entre outros [Rocha00].

Neste trabalho propomos que o professor dirija uma avaliação de interface feita por seus alunos, através da "Avaliação Heurística" que será apresentada na Seção 4.3. 


\section{Capítulo 3}

\section{A INFORMÁTICA NA EdUCAÇÃo}

Este capítulo discorre sobre a evolução e importância da utilização do ferramental de Informática na educação, bem como a própria evolução pedagógica no cenário nacional. São apresentadas as diferentes modalidades do software educacional, o estado da arte sobre avaliação da qualidade deste produto e as modalidades contempladas em nosso instrumento de avaliação. Finalizando, é relatado o contato feito com produtores de software educacional de Matemática direcionado ao Ensino Fundamental.

\section{III.I TendÊnCIAS Identificadas NA TradiçÃo PedagóGICA Brasileira}

A compreensão dos papéis de professor e aluno, da metodologia, da função social da escola e dos conteúdos a serem trabalhados estão sempre ligados a uma concepção de ensino e aprendizagem na prática do professor [PCN97a]. As atividades do processo ensino-aprendizagem refletem na prática do professor que, geralmente, é baseada em sua formação educacional e em seu percurso profissional. Inclui, desta forma, experiências escolares e de vida, na ideologia compartilhada com seu grupo social e nas tendências pedagógicas que lhe são contemporâneas.

As teorias de aprendizagem são fundamentadas nas teorias da Psicologia. Isto porque a Psicologia estuda, entre outros aspectos, o desenvolvimento e comportamento humano. 
As tendências pedagógicas no Brasil são influenciadas pelos grandes movimentos educacionais internacionais, mas sem deixar de lado especificidades de nossa história política, social e cultural. Na maioria dos casos, estas tendências empregam aspectos de mais de uma linha pedagógica, mas com características particulares.

Segundo os $\mathrm{PCN}^{6}$ [PCN97a], as seguintes tendências podem ser identificadas na tradição pedagógica brasileira: a "pedagogia tradicional", a "pedagogia renovada", o "tecnicismo educacional" e aquelas marcadas centralmente por preocupações sociais e políticas, "libertadora" e "crítico-social dos conteúdos".

A "pedagogia tradicional" é uma proposta de educação centrada no professor e a metodologia decorrente de tal concepção é baseada na exposição oral dos conteúdos, numa seqüência predeterminada e fixa, independente do contexto escolar. A ênfase é dada na necessidade de exercícios repetidos para garantir a memorização dos conteúdos. Esta metodologia se apóia no pensamento pedagógico positivista, corrente filosófica fundada por Augusto Comte, e é representado mais fortemente por Spencer, Durkheim e Whitehead [Gadotti94, cap.8].

A principal função da escola, nesse modelo, é transmitir conhecimentos disciplinares para a formação geral do aluno, mas, mesmo assim, não busca estabelecer relação entre os conteúdos ensinados e os interesses dos alunos, nem mesmo a relação entre estes conteúdos e os problemas reais que afetam a sociedade. A escola se caracteriza pela postura conservadora, onde o papel do aluno é de receptor passivo e o professor é visto

\footnotetext{
${ }^{6}$ PCN - Parâmetros Curriculares Nacionais: Constituem um documento do MEC/SEF - Ministério da Educação/Secretaria de Educação Fundamental - contendo propostas para a renovação da base curricular do Ensino Fundamental em todo o país. Os PCN trazem para a discussão nacional objetivos, conteúdos e critérios de avaliação escolar.
} 
como autoridade máxima. O conjunto de idéias pedagógicas e sociais dessa tendência na educação revela seu caráter conservador e reacionário.

A "pedagogia renovada" é uma concepção que inclui várias correntes ligadas ao movimento da Escola Nova ou Escola Ativa. Esta concepção valoriza o indivíduo e é centrada no aluno e não no professor ou no conteúdo, propondo a aprendizagem através da atividade pessoal do aluno. Pode-se dizer que a Escola Nova está centrada nas linhas de pensamento de Dewey, Montessori, Claparède e Piaget [Gadotti94, cap.10].

A Escola Nova destaca o princípio da aprendizagem por descoberta. Desta forma, o professor passa a ser visto como facilitador no processo de busca de conhecimento que deve partir do aluno. O professor deve organizar e coordenar as situações de aprendizagem, adaptando suas ações às características individuais dos alunos, para, assim, desenvolver suas capacidades e habilidades intelectuais.

Essa tendência teve grande penetração no Brasil na década de 1930 e, até hoje, influencia muitas práticas pedagógicas. Infelizmente, em muitos casos, essa idéia de ensino guiado pelo interesse dos alunos acabou por desconsiderar a necessidade de um trabalho planejado, perdendo-se de vista o que deveria ser ensinado e aprendido.

O "tecnicismo educacional" foi inspirado nas teorias behavioristas da aprendizagem e da abordagem sistêmica do ensino. Na educação, o behaviorismo está mais associado ao trabalho de Skinner, que está focado no comportamental de um indivíduo [Gadotti94, cap.16]. Segundo ele, o homem é considerado um ser manipulável, governado por estímulos do meio ambiente externo, que possui a função de moldar o seu comportamento. Para isso, contingências de reforço são planejadas a fim de que o 
desempenho do humano se aproxime do esperado. Segundo esta posição, o ser humano resulta de uma combinação de sua herança genética e das experiências que ele adquire na interação com o seu ambiente [Oliveira84].

A abordagem behaviorista define uma prática pedagógica altamente controlada e dirigida pelo professor, com atividades mecânicas inseridas numa proposta educacional rígida e possível de ser totalmente programada em detalhes [PCN97a]. A super valorização da tecnologia programada de ensino criou a falsa idéia de que aprender não é algo natural do ser humano, mas que depende exclusivamente de especialistas e de técnicas. Desta forma a valorização é dada à tecnologia e o professor passa a ser considerado um mero especialista na aplicação de manuais. Segundo Tarouco [Tarouco99], a atividade de aprendizagem é planejada de forma a serem oferecidas situações onde o estudante evidencie comportamentos desejados. Para isto são organizadas atividades de ensino e aprendizagem que visam a:

- treinar os estudantes para exibirem determinados comportamentos;

- usar reforço positivo para reforçar o comportamento desejado;

- usar reforço negativo para reduzir a freqüência do comportamento não desejado.

A Instrução Programada é uma ferramenta de trabalho nessa linha de ação e aplica os princípios de Skinner de comportamento humano. As características importantes desta estratégia são:

- apresentar a informação em seções breves;

- testar o estudante após cada seção;

- apresentar feedback imediato para as respostas dos estudantes. 
A função do aluno é reduzida a um indivíduo que reage aos estímulos de forma a corresponder às respostas esperadas pela escola, para ter êxito e avançar. Seus interesses e seu processo particular não são considerados e a atenção que recebe é para ajustar seu ritmo de aprendizagem ao programa que o professor deve implementar. Esta proposta ainda hoje é encontrada em muitos materiais didáticos com caráter estritamente técnico e instrumental.

\section{A "pedagogia libertadora" e a "pedagogia crítico-social dos conteúdos" firmam-} se no meio educacional, marcadas centralmente por preocupações sociais, econômicas e políticas. Isto ocorreu no final dos anos de 1970, quando educadores se mobilizaram em busca de uma educação crítica [PCN97a].

No Brasil, a "pedagogia libertadora" teve origem no final da década de 1950, e, após seu desenvolvimento ter sido interrompido pelo golpe militar de 1964, foi retomada no final dos anos de 1970. Esta pedagogia é pautada numa educação popular onde a atividade escolar é realizada por meio de discussões de temas sociais e políticos e de ações sobre a realidade social. Já a "pedagogia crítico-social dos conteúdos", que surge no final dos anos de 1970 e início dos anos de 1980, entende que não basta ter como conteúdo escolar as questões sociais atuais. Defende, também, a necessidade do domínio de conhecimentos, habilidades e capacidades mais amplas para que os alunos possam interpretar suas experiências de vida e defender seus interesses de classe. Alguns dos maiores representantes dessas pedagogias no Brasil são: Freire, Gadotti e Saviani [Gadotti94, cap.15].

A partir de 1980, surgiu um movimento que pretendia integrar as tendências didáticas que possuíam um viés mais psicológico com as outras, cuja inclinação era 
mais sociológica e política. Desta forma, não seria possível deixar de lado as preocupações com o domínio de conhecimentos formais para a participação crítica na sociedade, tampouco a necessidade de uma adequação pedagógica às características de um aluno que pensa, de um professor que sabe e aos conteúdos de valor social e formativo.

Esse momento se caracteriza pelo enfoque centrado no caráter social do processo de ensino e aprendizagem, e é marcado pela influência da Psicologia Genética.

A Psicologia Genética, por sua vez, possui como um de seus principais representantes o psicólogo suíço, Jean Piaget (suas idéias serão descritas logo a seguir, na Seção 3.1.1).

\section{III.I.I Os Novos Rumos da Educação}

Os novos rumos da educação indicam uma mudança de foco que passa a ser a aquisição de competências, através do desenvolvimento de habilidades nos domínios cognitivo, afetivo e psicomotor. Desta maneira, os conteúdos e a forma de abordagem dos mesmos devem usar, como critérios de seleção, a relevância, a contextualização e o amadurecimento dos alunos em cada fase de seu desenvolvimento [Moretto99].

Esses novos rumos, que possuem um enfoque centrado no caráter social no processo de ensino-aprendizagem, baseiam-se em reflexões construtivistas e, portanto, marcados pela Psicologia Genética. Um de seus maiores representantes é Piaget, que coloca na própria ação do sujeito a mola mestra de sua estrutura mental. 
Piaget preocupava-se em descobrir o caminho da busca do conhecimento. Seu sujeito não era o indivíduo em particular, mas o universal.

A Psicologia Genética propiciou aprofundar a compreensão sobre o processo de desenvolvimento na construção do conhecimento. Piaget focalizou o desenvolvimento ou evolução da criança, privilegiando os aspectos relacionados com a aprendizagem e os processos de cognição. Esta evolução, acompanhada desde o nascimento da criança, vai sofrendo um processo de maturação e desenvolvimento [Oliveira84].

Os estágios do processo de desenvolvimento são universais, embora cada criança possua características peculiares, sendo que o desenvolvimento da inteligência vem a ser uma adaptação da pessoa ao ambiente, adaptação esta que é essencialmente ativa e aprendida pelo sujeito em sua interação com o meio. As duas partes básicas do desenvolvimento da inteligência, segundo Piaget, são:

- Adaptação: processo de entrada da informação; e,

- Organização: processo de estruturação da informação.

Nesse sentido, os indivíduos não apenas respondem ao ambiente, mas atuam sobre ele.

A teoria de Piaget tem, portanto, um peso muito grande junto aos processos de aprendizagem, já que dá indicadores dos grandes períodos do desenvolvimento da inteligência, que aqui são sintetizados na Tabela 3.1.1.1. 


\begin{tabular}{|c|c|}
\hline ESTÁGIOS E SUBESTÁGIOS & CARACTERÍSTICAS PRINCIPAIS \\
\hline $\begin{array}{l}\text { 1. Sensório - motor } \\
\text { (nascimento até } 18 / 24 \text { meses ) }\end{array}$ & $\begin{array}{l}\text { Estágio pré-linguístico que não inclui internalização da } \\
\text { ação no pensamento; os objetos adquirem } \\
\text { permanência; desenvolvimento dos esquemas } \\
\text { sensório-motores; ausência operacional de símbolos. } \\
\text { Termina pela descoberta e combinações internas de } \\
\text { esquemas. }\end{array}$ \\
\hline $\begin{array}{l}\text { 2. Operações concretas } \\
\text { 2a.Pensamento } \\
\text { pré- operacional } \\
\text { (de } 2 \text { a } 7 \text { anos) }\end{array}$ & $\begin{array}{l}\text { Início das funções simbólicas; representação } \\
\text { significativa como linguagem, imagens mentais, gestos } \\
\text { simbólicos, jogos simbólicos, invenções imaginativas, } \\
\text { etc. Linguagem e pensamentos egocêntricos; } \\
\text { incapacidade de resolver problemas de conservação; } \\
\text { internalização das ações em pensamentos; ausência } \\
\text { de operações reversíveis. }\end{array}$ \\
\hline $\begin{array}{l}\text { 2b. Pensamento } \\
\text { operacional concreto } \\
\text { (de } 7 \text { a } 11 \text { anos) }\end{array}$ & $\begin{array}{l}\text { Aquisição de reversibilidade por inversão e relações } \\
\text { recíprocas; inclusão lógica; início de seriação; início de } \\
\text { agrupamento de estruturas cognitivas; entendimento } \\
\text { da noção de conservação de substância, peso, volume, } \\
\text { distância, etc.; início de relacionamento das operações } \\
\text { concretas com objetos, mas não com hipóteses } \\
\text { verbais. }\end{array}$ \\
\hline $\begin{array}{l}\text { 3. Operações formais } \\
\text { (de } 11 / 12 \text { até } 14 / 15 \text { anos) }\end{array}$ & $\begin{array}{l}\text { Raciocínio hipotético dedutivo. Proposições lógicas; } \\
\text { desenvolvimento máximo das estruturas cognitivas; } \\
\text { grupos, matrizes e lógica algébrica aparecem } \\
\text { proposicionais: esquemas operacionais que envolvem } \\
\text { combinações de operações. }\end{array}$ \\
\hline
\end{tabular}

TABELA 3.1.1.1 - ESTÁGIOS DO DESENVOLVIMENTO COGNITIVO PIAGETIANO [Oliveira84,pp.71]

Segundo nos diz Piaget, em Biologia e Conhecimento [Piaget73], ao organismo interessa manter-se o mais bem informado possível, e com isso torna-se necessário fazer o agrupamento das informações de modo cada vez mais coerente e econômico. Assim, a criança aprende, ao atingir o período operacional concreto - época em que inicia o seu Ensino Fundamental - a compor as informações em sistemas de representação, a associá-las, invertê-las, correspondê-las umas às outras, procurando uma forma sempre mais abstrata e metódica de combiná-las [Oliveira96]. 
Como pode ser observado na tabela apresentada, essa forma de arquivar informações passa por três grandes transformações estruturais. A primeira, marca a transição do período sensório-motor ao pré-operacional, quando a criança rompe os laços que a prendiam ao mundo físico, concreto, e passa a registrar seus dados, não só em seu próprio corpo, mas, também, de forma simbólica através de imagens mentais (figuras) ou signos verbais (palavras). A segunda marca a transição do período pré-operacional ao operacional concreto, quando a criança já consegue compreender o processo de escrita e do número como sistemas de representação e passa a prever e anunciar verbalmente o que vai fazer. E a terceira grande transformação marca a transição do período operacional concreto ao período das operações formais, ingressando aí o pensamento hipotético-dedutivo.

Ao contrário de algumas linhas de pedagogia construtivista, em que se desenvolvem idéias de que não se devem corrigir os erros, sendo que as crianças aprendem fazendo "do seu jeito", os PCN enfatizam o caráter construtivo do erro, quando o aluno tem a oportunidade de descobri-lo e corrigi-lo, sem deixar de valorizar a importância da intervenção do grupo e do professor no processo de aprendizagem de conteúdos específicos que favoreçam o desenvolvimento das capacidades necessárias à autoorganização.

No construtivismo, a idéia central é a de que a compreensão e aprendizagem são processos ativos, construtivos, generativos e de auto-reorganização [Tarouco99]. A inteligência necessita de organização no seu relacionamento com o ambiente. As estruturas são constituídas das propriedades de organização das operações e dos 
esquemas, que explicam comportamentos específicos e, quando organizadas, são o resultado da inteligência e têm, segundo Piaget, uma natureza lógica e Matemática.

\section{III.II A MATEMÁtICA No ENSINO FUndAMENTAL}

No século $X X$, podem ser identificados os seguintes movimentos de reforma do ensino da Matemática: o ensino de Matemática por repetição, no início do século; o ensino de Matemática por compreensão, em que no fundo, o trabalho do professor era resumido a um treinamento de técnicas operatórias que seriam utilizadas na resolução de problemas padrão; a Matemática Moderna cujo ensino foi influenciado por um movimento de renovação nas décadas de 1960 e 1970; e, a resolução de problemas que ganhou espaço no mundo todo no fim dos anos de 1970.

O movimento intitulado "Matemática Moderna" influenciou o ensino da Matemática em diferentes países. Nesta época, a pesquisa na área da Didática da Matemática se intensificou, pois os formuladores dos currículos insistiam na necessidade de uma reforma pedagógica, incluindo a pesquisa de novos materiais e métodos de ensino renovados. A Matemática era vista como uma via de acesso privilegiada para o pensamento científico e tecnológico [PCN97a] e o ensino passou, então, a ter preocupações excessivas com abstrações internas à própria Matemática, mais voltadas à teoria do que à prática, exagerando no formalismo, na axiomática. Mas ao aproximar a Matemática escolar da Ciência Matemática pura, esta reforma pedagógica não considerou um ponto básico: o que se propunha estava fora do alcance dos alunos, em especial, daqueles dos anos iniciais do Ensino Fundamental. 
Com o refluxo desse movimento, a resolução de problemas passou a ser o foco do ensino da Matemática nos anos de 1980 e foram dados novos rumos às discussões curriculares, que passaram a tratar da compreensão da relevância de aspectos sociais, antropológicos e lingüísticos na aprendizagem da Matemática.

Discussões no campo da Educação Matemática no Brasil e no mundo mostram a necessidade de se adequar o trabalho escolar às novas tendências da sociedade da informação onde a maioria das pessoas "precisa saber Matemática" e, agora, caminhando para uma sociedade do conhecimento que exige de todos "saber muita Matemática" [Onuchic99].

De acordo com trabalhos como os PCN [PCN97b] [PCN97c] e Onuchic [Onuchic99], a potencialidade do conhecimento matemático deve ser explorada da forma mais ampla possível no Ensino Fundamental e, com isto, levar o aluno, entre outros objetivos, a: compreender e transformar o mundo a sua volta; resolver situações-problema, sabendo validar estratégias e resultados, e até mesmo propor novos problemas; desenvolver formas de raciocínio; estabelecer conexões entre temas matemáticos e outras áreas, compreender procedimentos de contagem, de cálculo, de medição assim como processos estatísticos e probabilísticos. Com estas perspectivas, a Matemática pode contribuir ao desenvolvimento da cidadania.

Busca-se hoje utilizar os pontos positivos encontrados em reformas anteriores, tais como: a repetição, a compreensão, o uso da linguagem Matemática da teoria dos conjuntos, a resolução de problemas e, às vezes, até a exposição oral voltada ao ensino tradicional. Os estudos e pesquisas nesta área sofreram influências de teorias construtivistas, que se baseiam na Psicologia genética, sendo que o processo de 
ensino-aprendizagem atualmente busca uma orientação muito mais formativa do que informativa, o que se reflete no planejamento dos currículos em geral e, não apenas, no de Matemática.

Essa orientação, que se inicia já junto à educação infantil, para creches e préescolas no Brasil, salienta a importância da formação pessoal e social da criança, construindo sua identidade e autonomia. Numa leitura curricular transdisciplinar ${ }^{7}$, enfatiza, desde cedo, o estabelecimento de relações entre as mais diversas linguagens (além da verbal, oral e escrita), como a da Matemática, do movimento corporal, da música e das artes plásticas visuais. Machado [Machado91] faz a análise da impregnação mútua entre a Matemática e a língua materna, dois sistemas de representação, destacando a importância fundamental da mediação da língua no ensino da Matemática, visando, inclusive, a superar dificuldades em sua aprendizagem. Na sua visão, a língua e a Matemática constituem os dois sistemas básicos de representação da realidade [Machado93]. São instrumentos de expressão e de comunicação e, conjuntamente, constituem uma condição de possibilidade do conhecimento em qualquer área. Mas, a Matemática, apesar de estar presente em nosso dia-a-dia, muitas vezes é vista de forma totalmente dissociada da realidade e da língua que falamos.

Essa conjugação das linguagens numa forma dinâmica de ensinar, agilizando expressão e comunicação, propõe que se faça, através de conteúdos significativos para a criança, os chamados temas transversais. Estes abordam situações do seu dia-a-dia, portanto cheias de vida, e incentivam o registro e a análise do vivido através dos diferentes sistemas de representação, inclusive, naturalmente, o da Matemática,

\footnotetext{
${ }^{7}$ De um modo geral, a transdisciplinaridade constitui a generalização de um objeto que pode ser trabalhado em todas as disciplinas (ou pelo menos em muitas delas).
} 
associada (ou não) a outras formas, visando ao intercâmbio e à discussão. Com os temas tranversais, questões sociais podem ser trabalhadas numa perspectiva de transversalidade, pressupondo compromisso por professores de todas as áreas. Temas

como ética, orientação sexual, meio ambiente, saúde, além de outros relacionados à educação do consumidor, são propostos pelos PCN [PCN97a] [PCN97b] [PCN97c] com estas perspectivas, contribuindo assim, para a formação integral do aluno, com vistas à cidadania.

\section{III.III A INFORMÁTICA NO ENSINO FUNDAMENTAL}

A primeira iniciativa em relação à Informática na área educacional no Brasil, segundo Chaves [Chaves88], foi liderada pela SEI (Secretaria Especial de Informática) através da instituição da Comissão Especial de Educação, em 1980. Esta foi criada com o intuito de discutir as várias questões relacionadas à Informática e à educação. Em 1981, na cidade de Brasília, houve a realização do I Seminário Nacional de Informática na Educação. O evento foi organizado pela SEl em conjunto com o MEC (Ministério da Educação) e o CNPq (Conselho Nacional de Desenvolvimento Científico e Tecnológico), sendo dirigido a pesquisadores em Educação, Psicologia, Sociologia e Informática, além de representantes da SUCESU (Sociedade dos Usuários de Computadores e Equipamentos Subsidiários). Seu objetivo principal era discutir a utilização do computador como ferramenta auxiliar no processo de ensino e aprendizagem, bem como criar uma política norteadora da ação governamental neste processo. Deste seminário surgiu, como principal idéia, a implantação da política nacional de informatização da educação que tem como base a implantação de centros-piloto em universidades. No mesmo ano, em dezembro, as mesmas instituições em conjunto divulgaram o documento "subsídios para 
a implantação do Programa Nacional de Informática na Educação". O documento recomendava que as iniciativas nacionais deveriam estar centralizadas nas universidades e não nas secretarias de educação, a fim de primeiro construir o conhecimento técnicocientífico e depois transferi-lo à comunidade nacional.

É importante destacar que, decorrido mais de uma década do início de sua história, a Informática na área educacional no Brasil deve seus resultados aos precursores do projeto EDUCOM ${ }^{8}$ e aos inovadores centros-piloto, que cumpriram seu papel subsidiando as ações que hoje integram a atual política de informatização da educação brasileira. Esta política está baseada no Programa de Informática na Educação - PROINFO/MEC.

Nos tempos atuais, as escolas brasileiras de Ensino Fundamental e Ensino Médio ainda passam por um momento de descoberta e/ou consolidação do uso da Informática na educação. O total de escolas que adotaram o computador na prática educacional e o número de equipamentos adquiridos aumentou significativamente nos últimos anos. Mas, segundo Campos [Campos99a], as escolas, em sua maioria, não desenvolvem as atividades de Informática educativa no formato de projetos integrados e nem sempre enfatizam a preparação docente. O risco que estas escolas correm é de usar a tecnologia da Informática de forma marginal, não integrada às atividades curriculares e sem a efetiva participação dos professores. Na opinião dos especialistas entrevistados neste trabalho, dentro do possível, o computador deveria fazer parte da sala de aula possibilitando, com isso, uma visão de interdisciplinaridade.

\footnotetext{
${ }^{8}$ O projeto EDUCOM foi criado em 1983. Tinha por finalidade propor a orientação básica da utilização de tecnologias da informação no processo de ensino e de aprendizagem.
} 
O desafio, portanto, segundo os PCN [PCN97b] [PCN97c], para a escola e para o professor é o de como incorporar ao seu trabalho, apoiado na oralidade e na escrita, novas formas de comunicar e conhecer. O uso da tecnologia, além de renovar o processo ensino-aprendizagem, pode contribuir para o desenvolvimento integral do aluno, valorizando seus lados social, emocional, crítico e imaginário. O professor, explorando continuamente novas possibilidades pedagógicas, contribui com a melhoria de seu trabalho docente.

Para a psicóloga Nicolaci-da-Costa [Arantes99b], "da mesma forma que para a maior parte dos adultos, o rádio, o telefone ou a televisão não geraram impacto algum, pois já existiam quando nasceram, para as crianças de hoje o computador é somente uma das máquinas que fazem parte de seu mundo, ou seja, é natural". E, nas palavras do Prof. Dr. Eduardo Chaves [Barbeiro99], "na verdade uma das formas em que a gente aprende a usar a nossa capacidade cognitiva é interagindo com o meio ambiente, e este meio ambiente hoje é repleto de tecnologia ... Tentar fazer com que a educação se abstraia deste universo tecnológico em que a criança vive, para que depois, lá pelos quatorze anos, ela subitamente comece a interagir com este ambiente todo, me parece irrealista no mundo em que vivemos".

Cumpre destacar que não há consenso entre os educadores de que a utilização de software e computadores no Ensino Fundamental é, como um todo, positiva. Considerações contrárias ao uso de computadores neste ambiente podem ser encontradas em [Setzer94] e [Arantes99a]. 
Aspectos pedagógicos negativos observados pelo uso do computador no Ensino Fundamental, também foram identificados pelos especialistas entrevistados neste trabalho:

- Itacarambi [Gladcheff00f] aponta o problema de considerar que só o movimento leva ao conhecimento, não valorizando, assim, a reflexão (este aspecto deve ser trabalhado pelo professor através da organização de atividades, estabelecendo objetivos e procedimentos, e fazendo um fechamento correto);

- para Brandão [Gladcheff00d], um problema pode ser a possibilidade de dispersão do aluno (mas, segundo ele, este problema também pode ser encontrado em uma sala de aula que não faz uso desta tecnologia); e,

- Fernandez [Gladcheff00b] ressalta a ansiedade pela informação sem a efetiva reflexão do que está sendo informado (é preciso refletir sobre o que está sendo comunicado).

Para Valente [Valente93], as possibilidades de usar o computador como ferramenta educacional estão crescendo e os limites desta expansão são desconhecidos. A cada dia surgem novas maneiras de se usar o computador como um recurso para enriquecer e favorecer o processo de aprendizagem. Segundo ele [Valente91], as modalidades de uso desta ferramenta na educação apontam para uma nova direção: o uso desta tecnologia não como "máquina de ensinar" mas como uma nova mídia educacional. O computador passa a ser uma ferramenta educacional, uma ferramenta de complementação, de aperfeiçoamento e de possível mudança na qualidade do ensino. A presença do computador deve propiciar condições para os estudantes exercitarem a capacidade de procurar e selecionar informação, resolver problemas e aprender independentemente. E, segundo Holmes [Holmes99], é preciso dispersar a ilusão de que o computador por si só 
pode educar. O computador não pode ser visto como um possível tutor automatizado que transmite informações para o estudante. Mesmo que a automação do processo educacional de ensino e aprendizagem proporcione elementos de interatividade para o aluno, pelo fato deste processo ser muito complexo, esta tarefa não pode ser automatizada por completo [deLyra97]. O contato humano tanto entre professor/aluno como aluno/aluno não deve ser eliminado, ao contrário, deve-se permitir que o uso da tecnologia implemente novas formas de comunicação interativa, incluindo a pessoa humana como parte essencial do sistema.

Assim, deve ser ressaltado que o objetivo fundamental da utilização de computadores no processo educacional é fazer com que o computador seja utilizado como uma ferramenta, adaptando-se aos diferentes estilos de aprendizado, aos diferentes níveis de capacidade e interesse intelectual, e às diferentes situações de ensinoaprendizado. Segundo os especialistas entrevistados, a responsabilidade do professor em relação à aprendizagem do aluno independe do recurso que utiliza. Ele deve estar sempre perto ajudando, desafiando, problematizando. Deve ser o grande coordenador do projeto do conhecimento dos alunos e ter muita clareza de que a Informática não veio para substituí-lo.

O professor sofre, com isso, uma mudança de papel na educação [Joly95]. Passa de autoridade e portador do saber para agente facilitador deste saber, interagindo continuamente com o aluno e possibilitando também seu próprio aprendizado. 
No processo ensino-aprendizagem, o uso do computador pode, além de outras contribuições [Joly95]:

- auxiliar a motivação numa etapa inicial de desenvolvimento de um certo conteúdo;

- em uma etapa de conceituação, permitir ao aluno "operar" e descobrir regras, relações e até mesmo o próprio conceito;

- em uma fase de fixação, repetir as atividades a serem memorizadas de formas variadas com feedback imediato;

- em uma fase mais adiantada, generalizar e ampliar a aprendizagem.

O bom uso do computador pode depender da formação de professores, na medida em que é considerado mais um recurso de ensino, pedagógico ou de aprendizagem disponível na sala de aula e não o único e nem, talvez, o mais importante. Para isto, não só é preciso que os professores sejam "treinados" para que desenvolvam uma atitude positiva e cooperativa para com o uso dos computadores, mas também para que adquiram "competência" para utilizá-los em sala de aula.

O processo ensino-aprendizagem com a utilização dessa ferramenta, pode ser trabalhado em três níveis, segundo Oliveira [Gladcheff99]: momentos em que o professor realmente ensina numa posição hierarquicamente superior, de transmissão de conhecimento; num segundo momento mais transversal, de troca, de aprendizagem junto com os alunos; e depois, num terceiro momento, o professor se abstém, tendo uma atitude mais discreta, onde os alunos entram de forma mais atuante. Mas é preciso ressaltar que quanto menor a criança, o tempo de utilização do computador deve ser mais restrito. No ponto de vista dos especialistas entrevistados, o computador é uma 
ferramenta de trabalho como qualquer outra. Sua utilização como um fim em si mesmo não é válida. Um projeto de trabalho deve sempre ser desenvolvido e o computador fará parte deste, na medida em houver oportunidade e justificativa. Sua utilização depende, portanto, do conteúdo, da intenção e da situação, sempre por uma questão de sentido (existe razão efetiva para a utilização do computador?) e contexto (o computador se encaixa adequadamente ao ambiente em que o processo educacional se encontra no momento?).

\section{III.III.I A Informática no Ensino Fundamental de Matemática}

Um grande desafio do educador matemático, hoje, é o de trabalhar com os seus alunos a habilidade de pensar matematicamente, de forma a tomar decisões baseando-se na inter-relação entre o sentido matemático e o situacional do problema. Isto, pois, esta característica é o que realmente possui importância nas situações de trabalho atuais [Magina98]. É preciso que o educador tenha em mente que a utilização dessa ferramenta, o computador, pode realmente contribuir para a criação de um cenário que ofereça possibilidades para o aluno construir uma ponte sólida entre os conceitos matemáticos e mundo prático.

O uso da tecnologia traz, também, uma mudança no mercado de trabalho. Esta mudança se dá na valorização do indivíduo que tem flexibilidade de aprender e de se adaptar a mudanças cada vez mais rápidas [Frant98]. Olhando o computador como uma ferramenta educacional, é possível destacar um ponto positivo de sua utilização: permitir que o aluno construa, elabore e defina, em conjunto com o professor, os projetos, estratégias e/ou procedimentos a serem tomados, de maneira ativa e interativa. Este contexto contribui na capacitação do indivíduo para este mercado. Segundo Magina 
[Magina98], esta característica pode ser entendida como viável, devido a algumas propriedades que podem estar embutidas na ferramenta utilizada, tais como: a possibilidade de feedback imediato, simulação de situações e fenômenos, a facilidade de construção e reconstrução de gráficos, a capacidade de movimentação de figuras na tela do computador, ou até mesmo o uso de códigos fazendo com que o aluno comande a ferramenta por meio de ordens claras, diretas e lógicas.

De acordo com os PCN [PCN97b] [PCN97c], o computador é apontado como um instrumento que traz versáteis possibilidades ao processo de ensino e aprendizagem de Matemática, referente ao Ensino Fundamental, seja pela sua destacada presença na sociedade moderna, seja pelas possibilidades de sua aplicação neste processo. Tudo indica que seu caráter lógico-matemático pode ser um grande aliado do desenvolvimento cognitivo dos alunos.

A influência Piagetiana, como já mencionado, vem sendo muito forte em psicopedagogia, podendo inclusive vir a facilitar a observação de aspectos positivos na utilização do computador no Ensino Fundamental de Matemática, pois o modelo Piagetiano, sendo um modelo bio-matemático, propõe que a inteligência funcione conjugando a lógica Matemática binária à semântica, ou seja, ao significado da história de vida. Piaget transpõe as operações mentais para um modelo algébrico, sendo que a criança do período operacional concreto, aproximadamente de 7 a 11 anos, aprende a agrupar, compor, associar, inverter, classificar, seriar, e assim por diante, mas sempre com referência a dados do concreto. Ora, o computador, segundo Oliveira [Gladcheff99], sendo um instrumento lógico e simbólico, pode vir a contribuir muito para que a criança aprenda a lidar com sistemas representativos simbólicos, lingüísticos e/ou numéricos. 
Assim, pode não apenas consolidar a construção do número, como também construir o alicerce da inteligência mais abstrata que virá depois, ou seja, a inteligência formal propriamente dita, que é a que vai trabalhar com os possíveis, com as hipóteses, com as deduções. Desta forma, a criança não vai trabalhar mais só com agrupamentos, mas também com os grupos algébricos.

Mas a utilização do computador pode também possuir aspectos psicopedagógicos considerados negativos [Gladcheff99]. Um deles está relacionado ao referencial de contato com a realidade. Quanto menor a criança, maior deve ser o contato com o concreto, com o físico, com aquilo que ela pode manipular. O trabalho com o virtual deve ser introduzido aos poucos, e esta passagem nunca pode ameaçar o físico. Um outro risco do computador é a criança entrar no virtual via fuga e não via criatividade, ou seja, ela pode não se utilizar do computador como um instrumento de criatividade, mas sim como um instrumento de refúgio, para se esconder de situações sociais ou mesmo do medo de perder em um jogo, pois, para ela, o computador não é considerado uma ameaça.

Ao pensarmos no computador como ferramenta para auxiliar no ensino, mais especificamente no de Matemática, estamos nos referindo aos aplicativos que usamos com a finalidade de nos ajudar no processo de ensino-aprendizagem desta disciplina. Desta forma, é preciso que o educador procure aspectos considerados positivos no software a ser utilizado em suas aulas, visando a ampliar a inteligência de seus alunos.

A inteligência por muito tempo foi vista essencialmente como uma capacidade lógica, sendo que os testes de QI são baseados em raciocínios lógico-matemáticos e lingüísticos [Gladcheff99]. Hoje em dia, muitas outras vertentes da inteligência em suas 
múltiplas combinações são pesquisadas [Gardner94]. Pode-se dizer que a inteligência é a capacidade de descobrir, inventar e trabalhar com relações de qualquer tipo. Neste sentido, um software pode favorecer, por exemplo, a descoberta, que é mais fácil que a invenção. A descoberta de uma relação pode estar baseada em indícios ou não, de acordo com o nível de abstração de quem observa. Potencialmente, o caminho de agilização da inteligência pode ser trabalhada em um software, quando este provoca a criança a pensar, num desafio lúdico, onde ela não se sente por demais pressionada. Quanto mais for incentivada a descobrir relações, mais passará a inventar relações, que podem ser temporais, objetais, causais ou espaciais. A criança passará também a fazer combinações entre estas relações. O software pode, por exemplo, proporcionar situações onde a criança seja desafiada a trabalhar com o aqui e com o que está distante, para depois seriar nesta trajetória várias distâncias, relacioná-las entre si, descrevê-las e compor situações. A composição pode evoluir da articulação de dados entre si à combinatória de hipóteses, o que supõe a transposição dos dados da realidade para proposições verbais, com a utilização da lógica formal. Vemos como o tempo todo a inteligência trabalha conciliando as diversas linguagens.

Uma das grandes vantagens do computador é que ele dá um retorno visual e auditivo (perceptivo) daquilo que a criança compôs virtualmente, o que lhe serve para reformular seus projetos e idéias. Com isso, aprende também a fazer pesquisa. Uma outra vantagem, segundo Brandão [Gladcheff00d], é que o computador "força" uma mudança na dinâmica da aula, pois privilegia a discussão entre os alunos. Na opinião de Oliveira [Gladcheff99], existem ocasiões para o emprego da aprendizagem individualizada ou em grupo. No entanto, o computador pode e deve ser utilizado em grupo e, também, de forma combinada, como por exemplo, com artes plásticas, cênicas. A idéia, segundo 
ela, é que o computador faça parte do dia-a-dia das crianças.

\section{III.IV As DifERENTES Modalidades do SofTWARE Educacional}

As possíveis maneiras de se utilizar o computador no ambiente educacional podem ser separadas, segundo Chaves [Chaves88], pelas formas com que são efetuadas. São elas:

- auxílio na administração escolar e educacional;

- utilização para o ensino da própria computação;

- utilização no processo de ensino e aprendizagem das disciplinas curriculares.

O computador pode possuir várias maneiras de auxiliar o processo pedagógico. Isto depende das finalidades com que é usado. Alguns objetivos apontados por Cristovão [Cristovão97a], podem ser: proporcionar aprendizado de conteúdos, desenvolver habilidades e capacidades, ser instrumento de uma disciplina, auxiliar nas atividades do dia-a-dia, fornecer um espaço de comunicação, proporcionar diversão/passatempo.

$\mathrm{Na}$ administração escolar e educacional, o computador pode ser utilizado com o objetivo de auxiliar nas tarefas rotineiras destes setores. Podem ser utilizados na contabilidade geral da escola, folhas de pagamento, elaboração de orçamentos, projeção de despesas, em arquivos de endereços, emissão de carnês, etc. Também podem auxiliar nas tarefas secretariais de datilografia, facilitando a redação de cartas e ofícios, circulares para e de professores, programas de curso, roteiros, etc. Em tarefas como arquivar os nomes, endereços, séries e classes dos alunos, o histórico de suas notas, análises estatísticas do desempenho das classes e outras mais, podem ser perfeitamente usados. Enfim, a aplicação dos computadores na execução (ou no auxilio) das tarefas da 
administração escolar e educacional facilita muito o fluxo destas atividades [Chaves88].

Com a popularização dos computadores e seu barateamento relativo, habilitações profissionalizantes na área de Informática passaram a ser uma opção interessante e viável para as escolas. Portanto, o uso destas ferramentas para o ensino da própria computação possui relevância em termos de preparo para o exercício de muitas profissões. Hoje em dia, habilitações como o conhecimento de conceitos gerais de computação, digitação, utilização de planilhas eletrônicas, programação, etc, estão sendo cada vez mais solicitadas.

Na última década, a disciplina de Engenharia de Software Educativo e seu campo de ação tornaram-se um dos domínios de trabalho interdisciplinar mais desafiadores [Galvis-Panqueva97]. Esta disciplina refere-se à criação de ambientes educativos computadorizados, ou seja, concentra-se em materiais educativos computadorizados que são elaborados com uma finalidade específica: utilizá-los no processo de ensino e aprendizagem das disciplinas curriculares. Neste trabalho, nos interessa este tipo de abordagem.

Baseando-nos na literatura [Campos99b] [Chaves88] [Cristovão97a] [Dantas00] [Leite96] [PCN97a] [Valente91] [Valente93], sugerimos a seguintes modalidades de softwares educacionais, desenvolvidos com a finalidade descrita anteriormente:

- Instrução Programada;

- Simulação e Jogos Pedagógicos;

- Aprendizagem por Descoberta;

- Sistemas Hipermídia. 
Os pacotes aplicativos, apesar de não terem sido desenvolvidos com uma finalidade educacional, podem ser utilizados no processo de ensino e aprendizagem, como relata Dantas [Dantas00]. Os pacotes aplicativos genéricos, como processadores de texto, gerenciadores de bancos de dados, planilhas eletrônicas, etc, têm sido grandes aliados para muitos educadores. Estes têm concluído que seu uso não é só uma maneira interessante e útil de apresentar o computador aos alunos, mas que existem maneiras muito interessantes de explorá-los pedagogicamente. Existe também um outro tipo: ambiente de construção. Neste o aluno tem a oportunidade de construir algo através da exploração auto-dirigida, ou mesmo sugerida pelo mediador, quer seja o próprio professor ou o próprio software educacional. Não é visto como uma simulação, já que o resultado da ação pode ser antecipado pelo aluno e é exatamente o desejado. Também não é considerado um software de programação, pois o aluno não possui um histórico das operações já realizadas, mas explora o ambiente livremente a fim de atingir um determinado objetivo. Como exemplo, podemos citar os programas que permitem ao aluno construir estórias em quadrinhos, ou os softwares de autoria. Este tipo também pode apresentar maneiras interessantes de ser explorado pedagogicamente.

As modalidades sugeridas são descritas a seguir.

\section{III.IV.I Instrução Programada}

A instrução programada consiste em dividir o material a ser ensinado em pequenos segmentos logicamente encadeados e denominados módulos. Cada fato ou conceito é apresentado em módulos seqüenciais. O estudante deve ler o fato ou conceito e é imediatamente questionado. Se a resposta está correta, o aluno pode passar para o próximo módulo. Se a resposta é errada, a resposta certa pode ser fornecida ou o aluno 
é convidado a rever módulos anteriores ou a realizar outros módulos cujo objetivo é remediar o processo de ensino. Normalmente, softwares deste tipo começam pedindo o nome do aluno e o nível de dificuldade que deseja enfrentar.

Dentro das várias formas de instrução programada, os programas de exercício e prática talvez sejam a maneira mais comum de utilização do computador na educação. Estes programas são utilizados para revisar o material que foi visto em classe, especialmente aquele que envolva memorização e repetição, apresentando exercícios logo de início. Requerem resposta imediata do aluno, propiciando feedback também imediato e exploram características gráficas e sonoras do computador. São também indicados para permitir que os alunos mais avançados possam progredir na matéria em ritmo mais acelerado, ou mesmo permitir que alunos defasados possam alcançar os outros, trabalhando fora do horário normal. Uma das vantagens do uso destes programas é o fato do professor dispor de uma infinidade de exercícios que o aluno pode resolver de acordo com o seu grau de conhecimento e interesse. Podem também fazer uso de jogos na forma de apresentação de seus exercícios.

Uma outra variedade são os tutoriais. Estes constituem a versão computadorizada da instrução programada por completo, ou seja, antes de o aluno ser questionado, informações são apresentadas. Uma das vantagens dos tutoriais é o fato de poderem apresentar o material/assunto a ser trabalhado com algumas características que não são permitidas no papel, tais como, animação, som, vídeo e a possibilidade do professor ou até mesmo o próprio aluno manter um controle sobre seu desempenho. São bastante utilizados por permitirem a introdução do computador na escola sem provocar muita mudança, pois é a versão computadorizada do que pode já ocorrer na sala de aula. 
Existe software voltado especificamente para auxiliar o professor a montar esse tipo de programa educacional. Tal software interage com o professor permitindo-lhe que insira textos, questões de múltipla escolha, comentários, etc. Um outro software, às vezes chamado do courseware, é geralmente utilizado pelo aluno para acessar o material elaborado pelo professor ${ }^{9}$.

Os bons programas tutoriais utilizam técnicas de inteligência artificial (pesquisa em tutores inteligentes) para analisar padrões de erro, avaliar estilo e a capacidade de aprendizagem do aluno, assim como oferecer instrução especial sobre o conceito que o aluno está apresentando dificuldade.

O seu objetivo principal é levar o computador a instruir o aluno, em uma determinada área do conhecimento, em um contato individualizado (próximo à maneira que um tutor o faria, mas, obviamente, com diferenças cruciais).

Com certeza, a tarefa de programação de tutoriais sofisticados é extremamente difícil. Com isso, é muito grande o risco de acabarem tornando-se exercícios repetitivos, que, mesmo com o uso de animação ou gráficos, perderiam muito de sua criatividade.

A demonstração é uma técnica didática presente no repertório da maioria dos professores e, geralmente, está associada ao uso de transparências em retroprojetor. No caso da Matemática temos, como exemplo, quando o professor deseja mostrar a seus alunos o comportamento de funções que possuem aspectos semelhantes ou mesmo a demonstração do teorema de Pitágoras via Geometria. A utilização de um computador pode auxiliar esta técnica em sala de aula com incríveis graus de sofisticação. Pacotes

\footnotetext{
${ }^{9}$ Alguns softwares deste tipo podem ser encontrados em [Mace99].
} 
demonstrativos estão sendo desenvolvidos por empresas de software para utilização em sala de aula. Estes fazem uso de recursos gráficos, sonoros e combinação de cores. Portanto, possuem um potencial muito mais rico do que as demonstrações realizadas com giz e quadro negro ou com transparências. Poderíamos dizer que fazem parte de uma simulação, mas sem a interação com o aluno, caracterizando-se mesmo como uma mera "demonstração"9.

\section{III.IV.II Simulação e Jogos Pedagógicos}

Os softwares de simulação implicam na criação de modelos simplificados do mundo real e são riquíssimos, pois envolvem modelos de sistemas complexos dinâmicos. Estes modelos permitem a exploração de situações fictícias, de situações com risco, de experimentos que são muito complicados, caros ou que levam muito tempo para serem executados.

Hoje em dia, os computadores já possuem capacidade de simular sistemas razoavelmente complexos. Podem ser programados para responder a determinadas intervenções de maneiras realistas, processando significativas quantidades de dados. Por isso, simulações pedagogicamente relevantes podem ser realizadas com grande complexidade e realismo.

As simulações oferecem ao aluno a possibilidade de desenvolver hipóteses, testálas, analisar resultados e refinar os conceitos. Desta forma, o aluno passa a ser um sujeito pertencente a seu cenário, tendo um bom controle das situações hipotéticas e obtendo os resultados provenientes de sua interação. Oferecem também um ambiente muito útil para o trabalho em grupo, onde vários grupos podem testar hipóteses diferentes, e com isso 
obter um contato mais "real" com os conceitos envolvidos no problema que está sendo estudado. Mas simulações devem ser vistas como um complemento às apresentações formais, leituras e discussões em salas de aula. Sem estas complementações não existe a garantia do aprendizado, nem mesmo a garantia de que o conhecimento possa ser aplicado à vida real.

Os jogos pedagógicos distinguem-se de outros tipos de jogos basicamente pelo seu objetivo: têm como alvo explícito promover a aprendizagem. A pedagogia por trás desta modalidade é a exploração auto-dirigida ao invés da instrução explícita e direta. Com os jogos, aprende-se partindo da vivência lúdica e da reflexão sobre a mesma, que, do ponto de vista da criança, constituem a maneira mais divertida de aprender. Os jogos pedagógicos podem ser utilizados para a aprendizagem de conceitos que podem ser difíceis de ser assimilados pelo fato de não existirem aplicações práticas imediatas. Entretanto, o seu grande problema consiste no fato de que a competição pode desviar a atenção em relação ao conceito envolvido. Com isso, o objetivo passa a ser unicamente vencer no jogo e o lado pedagógico, de aprendizado, fica para segundo plano. Mas uma possível forma de contornar este problema é fazer com que o aprendiz reflita sobre a causa do erro que gerou uma jogada que não deu certo e com isso tome consciência do erro conceitual que estava envolvido naquela jogada.

A técnica do jogo pode ser empregada num software educacional a fim de aumentar, por exemplo, a motivação do aluno. Portanto, pode ser encontrada também em conjunto com simulações, tutoriais ou softwares do tipo exercício e prática. 
Alguns fatores podem ser considerados determinantes para a caracterização de um jogo pedagógico:

- a capacidade de provocar curiosidade no aluno;

- a quantidade de desafios, sendo bem dosados para não provocar ansiedade nem desinteresse no aluno;

- aspectos lúdicos diversos e próprios à faixa etária destinada;

- o aluno deve por si só ter vontade de utilizá-lo;

- deixar o aluno envolvido e constantemente ativo.

\section{III.IV.III Aprendizagem por Descoberta}

Há, hoje em dia, várias linguagens de programação para a área da educação. $\mathrm{A}$ mais antiga e famosa é a linguagem LOGO. Esta também é a que dá mais ênfase à aprendizagem ou à auto-aprendizagem, e está se tornando uma das mais utilizadas em contextos educacionais e uma das mais populares em computadores.

LOGO não é só o nome de uma linguagem de programação, mas, também, de uma filosofia da educação. Foi desenvolvida nos anos de 1960, no MIT - Massachusetts Institute of Technology, em Cambridge, sob a supervisão do Prof. Seymour Papert [Papert94] [Papert85]. A filosofia emergiu dos contatos de Papert com Piaget, e com as pesquisas do MIT e outros centros de estudo, sobre o problema da inteligência artificial.

Segundo Chaves [Chaves88], a filosofia da educação que a fundamenta parte do seguinte pressuposto: muitas das coisas que uma criança aprende são, sem dúvida, decorrentes de um processo de ensino deliberado e formal. Mas muitas outras ela 
aprende através da exploração, da busca e da investigação. Esta última não é decorrente do ensino, pelo menos não do ensino formal e deliberado, e pode ser caracterizada como uma verdadeira auto-aprendizagem. Várias filosofias da educação têm enfatizado a importância deste tipo de aprendizagem para a formação intelectual da criança. Assim como outros estudos, esta filosofia defende que aquilo que a criança aprende porque fez, porque investigou, porque descobriu por si mesma, não só tem um significado especial para o desenvolvimento de suas estruturas cognitivas, como é retido por mais tempo.

A linguagem possui excelentes recursos gráficos, em alta resolução, manipuláveis tanto em modo de execução imediata como por programas, através de comandos bastante simples, mas poderosos. Estes recursos, centrados na famosa "tartaruga" (um cursor gráfico que se tornou o símbolo da linguagem LOGO), permitem à criança desenhar na tela com relativa facilidade. Desta forma, possui uma grande vantagem em relação aos desenhos com lápis e papel: ao desenhar na tela, a criança é forçada a pensar sobre o que está fazendo e, neste processo, aprende coisas muito importantes não só sobre o projeto que está desenvolvendo, mas também sobre como ela própria pensa e como o computador funciona. Segundo as palavras da Prof.a Basili [Gladcheff00e], "as crianças menores, por exemplo, trabalham muito com lateralidade de uma forma diferente ... precisam ficar paradas, e tentar verificar a posição do objeto (tartaruga) em relação a elas ... desta forma têm uma visão mais espacial de lateralidade, diferente de como estão acostumadas a trabalhar, ou seja, elas próprias sempre mudando de posição".

Mas, embora seja dedicada especificamente ao trabalho educacional com crianças, essa não é uma linguagem voltada apenas para elas. Possui poderosos recursos para 
manipulação de palavras e listas, e com isso, se torna muito utilizada em trabalhos sofisticados de inteligência artificial. Isto significa que a criança pode começar com a parte gráfica e ir gradativamente progredindo até tornar-se, se assim o desejar, competente em todos os aspectos que uma linguagem de programação bastante completa pode oferecer.

\section{III.IV.IV Sistemas Hipermídia}

Segundo Pimentel [Pimentel89], o termo hipertexto é atribuído a Ted Nelson que o criou em 1960, referindo-se aos primeiros sistemas construídos com a filosofia de ligações embutidas. E, para Lévy [Lévy96], a abordagem mais simples para este termo é a de descrevê-lo, por oposição a um texto linear, como um texto estruturado em rede.

Hoje, com a digitalização do som e da imagem, a multimídia é utilizada num contexto que engloba textos, gráficos, som e figuras.

O termo hipermídia é considerado como uma extensão do termo hipertexto. Implica na ligação e navegação através de materiais armazenados em diferentes mídias: texto, gráficos, som, música, vídeo, etc. Sendo assim, pode ser colocado como uma combinação de hipertexto com a multimídia.

Portanto, sistemas hipermídia são sistemas criados para manipulação, apresentação e representação da informação onde:

1. as informações são armazenadas em uma coleção de nós (os elementos de informação, parágrafos, páginas, etc) multimídia;

2. existem ligações entre esses nós (referências, notas, indicadores, "botões" que efetuam a passagem de um nó a outro), habitualmente conectados pelos chamados 
"links";

3. os usuários podem acessar a informação, "navegando" através das estruturas disponíveis nos nós.

A leitura de uma enciclopédia clássica já é de tipo hipertextual, uma vez que utiliza ferramentas de orientação tais como: dicionários, índices, quadros de sinais, sumários, etc [Lévy96]. No entanto, o suporte digital apresenta diferenças consideráveis em relação aos hipertextos anteriores à Informática. Como exemplos: o uso dos instrumentos de orientação (mapas) e a passagem de um nó a outro com grande rapidez, sem esquecer dos efeitos sonoros embutidos. Estes sistemas geralmente são encontrados em CDROMs, e apenas permitem a consulta de informações através de técnicas como a hipermídia. Assim, podem ser utilizados como fonte de informação, um poderoso recurso para alimentar o processo de ensino-aprendizagem.

Os sistemas hipermídia também podem ser encontrados na grande rede de computadores "Internet".

Esses sistemas podem ser extremamente abertos e possuir um grau elevado de interatividade com o usuário. Aqueles com alto grau de interatividade adotam formas abertas de navegação, ou seja, permitem a descoberta imprevista e a descoberta de exploração livre. Já os que possuem grau de interatividade baixo restringem a liberdade de navegação, ou seja, privilegiam a aprendizagem de recepção direcionada, a exposição indutiva (conjunto de informações que induzem o usuário a seguir os próximos passos) e a exposição dedutiva (conjunto de informações que levam o usuário a deduzir o próximo passo, como uma conseqüência lógica). Os sistemas hipermídia com média interatividade podem assumir um enfoque híbrido de navegação, ou seja, permitem a descoberta 
guiada onde ora o usuário navega livremente na rede, ora navega em caminhos prédefinidos.

Os sistemas hipermídia privilegiam o controle das lições pelo aprendiz. O sucesso da aprendizagem está no interesse, inteligência e habilidade do aprendiz em tomar decisões sobre seqüência e ênfase. Mais do que apresentar a informação conectada em nós (ligações), os ambientes de aprendizagem de hipermídia permitem uma reflexão sobre o conteúdo que está sendo utilizado.

\section{III.V Avaliação da Qualidade do Software Educacional}

A quantidade de programas educacionais e as diferentes modalidades de uso do computador mostram que esta nova tecnologia pode ser bastante útil no processo de ensino-aprendizado. Mas a assimilação desta tecnologia só se justifica na medida em que possibilite um avanço qualitativo no sistema educacional [Oliveira87]. O computador, considerando suas potencialidades, se usado de forma adequada pode tornar-se um agente de mudanças capaz de alterar a realidade escolar, possibilitando, talvez, melhores resultados do que os hoje observados. A interação entre aluno/computador/professor se dá através da utilização de softwares. Desta forma, é fundamental que se coloque em reflexão o tema "Avaliação da Qualidade de Software Educacional", discutindo em que medida um software pode contribuir para a educação hoje questionada ou em que medida poderá concorrer para uma educação transformadora.

Apesar do termo "avaliar" possuir muitos significados, no tema sugerido significa: analisar como um software pode ter um uso educacional, como pode ajudar o aluno a construir seu conhecimento e a modificar sua compreensão de mundo, aumentando sua capacidade de participar da realidade em que vive [Vieira00]. Nesta perspectiva, uma 
avaliação criteriosa pode contribuir para apontar em que tipo de proposta pedagógica o software em questão poderá ser melhor aproveitado. Segundo Saraiva [Saraiva98], as tecnologias aplicadas à educação devem obedecer a um projeto pedagógico consistente e coerente com as finalidades educativas. Por isto, antes de utilizá-lo em suas aulas, é muito importante que os educadores sejam capazes de identificar se um software atende, ou não, aos objetivos educacionais por eles traçados.

O software educacional faz parte de uma estrutura complexa onde os requisitos de qualidade possuem, além das caraterísticas técnicas, características ligadas à educação, ou seja, aspectos envolvidos no processo de ensino-aprendizagem que incluem variáveis pedagógicas, lúdicas, psicopedagógicas, culturais, entre outras.

Assim sendo, um programa de avaliação da qualidade para software educacional deve ser elaborado não apenas com base nas características técnicas de qualidade descritas na Norma ISO/IEC 9126-1, mas também nas características ligadas ao processo educacional. A perspectiva, em termos de avaliação de software educacional, é a de valorizar fundamentalmente o aspecto educacional, submetendo a ele todos os demais critérios de apuração da qualidade e pertinência deste software.

Segundo Oliveira [Gladcheff99], em uma perspectiva psicopedagógica, um software deve levar em conta características formais e de conteúdos, como qualquer instrumento de ensino-aprendizagem. Do ponto de vista piagetiano, ao se analisar um software, devem ser levados em conta aspectos formais, verificando se "ele está ajudando a criança a desenvolver a sua lógica, a raciocinar de forma clara, objetiva, coerente, criativa?" e aspectos em relação ao conteúdo, ou seja, "a temática deste software tem um significado atraente para a realidade de vida desta criança?". Deve-se sempre conjugar 
forma e conteúdo, sintaxe com semântica.

O instrumento de avaliação gerado com este trabalho (apresentado na Seção 6.2), aborda aspectos técnicos de um software (baseados nas Normas ISO/IEC) e aspectos ligados à área educacional de Matemática, direcionados ao Ensino Fundamental. Este instrumento permite que o professor (ou avaliador) reflita sobre, por exemplo, a possibilidade de o software:

- vir a ser utilizado dentro de uma abordagem com temas transversais;

- explorar a relação dos conceitos matemáticos trabalhados com outros conceitos da própria Matemática e/ou com conceitos de outras disciplinas;

- interagir o conhecimento matemático trabalhado com a realidade do aluno, a fim de que ele compreenda a Matemática como parte de sua vida cotidiana;

- poder contribuir para a estimulação da curiosidade e fantasia da criança.

Esses são apenas alguns aspectos tratados no instrumento de avaliação gerado com este trabalho.

$\mathrm{Na}$ literatura encontramos alguns trabalhos afins, como: Oliveira [Oliveira87] descreve algumas questões relativas a aspectos que constituem um conjunto mínimo para avaliação de um software educacional; Carraher [Carraher90] especifica alguns comportamentos desejáveis em um software educacional; Campos F. [Campos94a] define critérios para avaliação da qualidade de sistemas do tipo hipermídia educacional, na perspectiva de um usuário autor; Campos G. [Campos94b] propõe uma metodologia para avaliação da qualidade de software educacional, dando diretrizes para desenvolvedores e usuários; Baumgartner [Baumgartner96] apresenta um modelo heurístico para avaliar 
software educacional; Braga [Braga96] descreve orientações para o caso específico de softwares do tipo hipermídia; Leite [Leite96] propõe aspectos relacionados à avaliação de um sistema de tutoria inteligente; Cristovão [Cristovão97b] discute os quatro aspectos que influem na avaliação de um software educacional (computacional, conteúdo, de interface e cognitivo); CSR [CSR98] apresenta uma ficha para pontuar um software educacional, usado por crianças; Loureiro [Loureiro98] estabelece modelos lógicos de análise do software educacional; Campos F. [Campos99c] descreve um conjunto mínimo de características pedagógicas para avaliação da qualidade do software educacional.

Em situações específicas (como em nosso caso, softwares educacionais de Matemática, direcionados ao Ensino Fundamental), características particulares a este domínio são enfatizadas. Mas nem todos os aspectos enfocados são exclusivos da Matemática. Após interagirmos com alguns especialistas da área de Educação Matemática, pudemos constatar que para focalizarmos apenas aspectos exclusivos da Matemática, só seria possível ao abordarmos conteúdos específicos da própria Matemática. Mesmo assim, para cada bloco de conteúdos matemáticos que se configurem numa unidade, teríamos um instrumento diferente. Não sendo este nosso objetivo, decidimos, então, particularizar os aspectos ligados à Matemática num contexto geral, na medida do possível.

Sendo assim, o instrumento gerado neste trabalho, pode ser considerado mais apto para a avaliação da qualidade de produtos de software educacional de Matemática, direcionados ao Ensino Fundamental, do que outros trabalhos mais abrangentes. 
Gostaríamos de ressaltar que os questionários elaborados neste trabalho possuem tanto aspectos ligados aos novos rumos da educação com reflexões construtivistas (no que diz respeito à contextualização do conteúdo, resolução de problemas, interatividade e outros) como aspectos relacionados aos pontos positivos das correntes pedagógicas existentes (memorização, compreensão e outros). Isto porque, como já mencionamos na Seção 3.2 deste capítulo, a busca hoje é pela utilização de pontos considerados positivos das reformas pedagógicas do ensino da Matemática que ocorreram no século XX.

Dependendo da postura do professor, ele poderá se respaldar mais nas questões que refletem sua posição. Se possui uma postura tradicionalista, "talvez" deixe de lado algumas questões e se importe mais com aquelas que suportam tal posição, como por exemplo: aspecto seqüencial do software, a impossibilidade de erros, o reforço positivo para o acerto, o reforço negativo para o erro, entre outras. Possuindo uma postura ligada ao construtivismo vai se importar com questões que se referem: ao potencial que o software tem de permitir o levantamento de hipóteses, ao potencial que o software tem de permitir definições de caminhos diferenciados pelos alunos, à contextualização do conteúdo, entre outras. O que o software vai contribuir para suas aulas depende muito dos objetivos e planejamento traçados para sua utilização. Até mesmo softwares educacionais que possuem um aspecto tradicionalista, como por exemplo os tutoriais (instrução programada) ou softwares do tipo exercício e prática (repetição) podem conter características construtivistas.

Portanto, o objetivo deste trabalho foi definir e identificar características que apontem itens de qualidade (relativos ou não) dentro de um software educacional de Matemática, direcionado ao Ensino Fundamental, sem se prender a uma das correntes de 
ensino. Dentro da coleta de dados junto aos especialistas e outras fontes utilizadas, não se está especificando determinada corrente ou metodologia do ensino para distinguir a qualidade a ser destacada no produto, embora hoje as idéias construtivistas estejam bastante presentes nas discussões da Educação Matemática e educação como um todo.

\section{III.VI As Modalidades DE Software Educacional Contempladas No INSTRUMENTO DE AVALIAÇÃo GERADO}

Além das partes relacionadas a qualquer tipo de software educacional de Matemática direcionado ao Ensino Fundamental, o instrumento gerado com este trabalho contém módulos de avaliação específicos de acordo com a modalidade a ser analisada. As modalidades contempladas são: exercício e prática, tutorial, simulação, sistema hipermídia e jogo pedagógico.

De acordo com a psicopedagoga entrevistada [Gladcheff99], dependendo do tipo a ser utilizado, o software educacional poderá enfocar aspectos específicos no desenvolvimento da criança.

Os softwares do tipo exercício e prática, ou seja, aqueles que tratam de exercícios propostos referentes a um assunto já estudado, mesmo sendo direcionados a uma linha mais tradicional, podem ser utilizados com o intuito de consolidar a automatização da aprendizagem em uma linha pós-construtivista. Podem ser recomendados, também, para crianças que estejam com algum problema de aprendizagem, sejam problemas cognitivos ou mesmo de insegurança. Este tipo de software oferece um treino (o que é diferente de se desenvolver uma criatividade na criança), contribuindo, assim, para abaixar sua ansiedade podendo, então, liberar mais o seu raciocínio. 
Os softwares do tipo tutorial, que constituem uma versão computacional da instrução programada, podem ajudar a criança a desenvolver sua autonomia, a cortar o cordão umbilical da presença física do tutor. Este tipo de software também pode ajudar a criança a fazer uma auto-análise de como está pensando, pois ela tenta identificar, localizar seu erro e relacioná-lo com o que ocorreu antes e com o que ocorreu depois.

Os softwares de simulação, que implicam na criação de modelos simplificados do mundo real, são considerados muito ricos, pois envolvem modelos de sistemas complexos dinâmicos. Os sistemas dinâmicos estão sempre longe do estado de equilíbrio e supõem a constante transformação [Gladcheff99]. Uma transformação requer o trabalho com dois eixos: o da conservação e o da inovação. Este tipo de software exige que a criança identifique aquilo que ela conserva e aquilo que inova criando, desta forma, relações, elos e vínculos entre estes eixos. Com isso, a criança passa a compor elementos de uma forma dinâmica, o que é muito mais difícil do que de uma forma estática. Como um exemplo deste tipo de software, podemos citar a simulação de um processo de construção de gráficos de funções. Ao alterar (ou conservar) alguns parâmetros de funções de um certo tipo, é possível o aluno criar hipóteses e, posteriormente, visualizar as alterações ocorridas nos gráficos de tais funções.

Os sistemas hipermídia, também encontrados na Web, podem ser extremamente abertos e possuir um grau muito elevado de interatividade. Do ponto de vista psicopedagógico são muito bons, pois podem atrair a criança para uma metodologia de trabalho ao mesmo tempo organizada, lúdica, inventiva e cheia de surpresas. A semente da pesquisa começa a entrar na cabeça da criança tanto quanto a exploração e a descoberta de novas relações. Estas relações sempre conjugam dados espaciais, 
temporais, objetais e causais em dois níveis: no nível perceptível e no nível da memória. Com isto, estes sistemas podem ajudar a desenvolver a atividade em pesquisa, a autonomia, enfim, a inteligência da criança e consequentemente sua auto confiança.

E, por fim, os jogos pedagógicos, que não possuem uma especificidade em si. De uma certa forma, incluem as diversas categorias já mencionadas e correspondem à maneira mais divertida de aprender, no ponto de vista das crianças. O enfoque de diversão é ressaltado neste tipo de software. A idéia é levar a criança a trabalhar conceitos teóricos/matemáticos durante a prática do jogo. Neste contexto, a criança se torna mais receptiva e motivada para assimilar o conhecimento abordado.

Alguns dos requisitos específicos relevantes a cada modalidade apontados pelos especialistas entrevistados são:

\section{Exercício e Prática:}

$>$ se encaixar com o que foi trabalhado em sala de aula;

$>$ ser muito claro e objetivo na ordem com que apresenta os exercícios;

$>$ atender a todos os passos que um treinamento necessita;

$>$ possuir dificuldades gradativas;

$>$ ser representativo das dificuldades médias que o conteúdo trabalhado possui;

$>$ possuir conceitos corretos;

possuir uma grande variedade de possibilidades de aplicação do conceito trabalhado; 
2. Tutorial:

$>$ possuir definições matemáticas precisas, claras e completas;

$>$ ser "simples" e objetivo;

$>$ ser claro nas orientações para sua utilização;

não possuir muitas saídas, ou seja, ser direto na direção que a criança deve seguir;

$>$ possuir exemplos representativos das dificuldades de um usuário médio;

apresentar o conteúdo matemático atraentemente;

$>$ utilizar metáforas próprias à faixa etária a que se destina;

3. Simulação:

$>$ ser o mais próximo do real possível;

$>$ permitir ao aluno testar suas próprias hipóteses;

$>$ possuir um tempo adequado para a simulação, ou seja, não muito rápido ("estou numa brincadeira") nem muito lento ("estou numa simulação");

4. Sistema Hipermídia:

$>$ ser ligado a fontes fidedignas (caso esteja localizado na Web);

permitir um alto grau de interatividade;

dificultar que o aluno se perca, apresentando uma quantidade adequada de links; 
$>$ permitir que os alunos atinjam os mesmos objetivos, mesmo seguindo caminhos distintos;

$>$ proporcionar facilidade de navegação;

$>$ separar as informações por grupos;

5. Jogo Pedagógico:

levar em conta o que a criança já pode conhecer;

$>$ não substituir situações reais por situações matemáticas de forma artificial;

$>$ oferecer situações e recursos que justifiquem sua utilização, não apenas substituindo um livro didático;

$>$ fazer com que o aluno perceba que está trabalhando com Matemática, de uma forma lúdica;

$>$ ser "inteligente", não subestimando o aluno;

$>$ possuir dificuldades gradativas;

$>$ possuir detalhes para que a criança possa explorar;

$>$ possuir conteúdo significativo;

$>$ possuir uma proposta educacional;

$>$ não desvincular os exercícios matemáticos do jogo em si.

Citamos aqui, apenas alguns dos requisitos, pois, a listagem completa para cada um dos tipos é encontrada no próprio instrumento de avaliação gerado. 
Independente do tipo de software a ser manipulado é preciso, também, que a criança esteja motivada a utilizá-lo, para que, assim, influencie positivamente no desenvolvimento dela. Na opinião dos especialistas, a criança pode se sentir motivada a utilizar um software educacional quando:

- segundo Fernandez [Gladcheff00b], possui um jogo de cores, som, imagem, movimento e pouco texto. Em seu ponto de vista, o software deve ser dinâmico, permitir escolhas e dizer respeito à realidade do aluno, de seu mundo;

- segundo Basili [Gladcheff00e], é interativo;

- segundo Hessel [Gladcheff00a], oferece desafios e problematiza situações ou ações;

- segundo deFranca [Gladcheff00c], possui um lado lúdico;

- segundo Brandão [Gladcheff00d], possui animação, atrativo gráfico. Em seu ponto de vista, o software deve permitir que o aluno tire conclusões ou examine "coisas" novas interagindo bastante. Também, deve proporcionar a chance de "navegar";

- segundo Itacarambi [Gladcheff00f], é interativo. Mas, em seu ponto de vista, qualquer software, utilizado com embasamento em um projeto do professor pode ser motivador.

Levando em conta as opiniões relatadas, cada módulo de avaliação elaborado (relativo a um tipo específico de software educacional), procura evidenciar características específicas do tipo contemplado. O professor, ao utilizar um software dotado de tais características poderá aplicá-lo, considerando seus objetivos traçados e a necessidade de cada criança ou da classe como um todo. Para isso, sugerimos basear-se nas indicações psicopedagógicas apontadas. 


\section{III.VII A Produção no Brasil de Software Educacional de Matemática, DIRECIONADO AO ENSINO FUNDAMENTAL}

A produção de softwares educacionais no Brasil não é muito antiga. Mesmo assim, através do guia desenvolvido pela Edulink [Mace99], do site da Escola do Futuro ${ }^{10}$ e distribuidoras existentes, pudemos observar que é grande o número de produtos produzidos no Brasil. Sendo assim, contatamos vinte e oito empresas que produzem softwares de Matemática direcionados ao Ensino Fundamental, enviando-Ihes um questionário ${ }^{11}$ por nós elaborado com a finalidade de levantar alguns dados como:

- quando e por quê surgiu o interesse da empresa pela produção de softwares educacionais;

- qual o primeiro software de Matemática, direcionado ao Ensino Fundamental, desenvolvido pela equipe;

- em termos de conteúdo específico (Álgebra / Geometria / Aritmética / Probabilidade e Estatística), faixa etária e tipo (Jogo / Simulação / Exercício e Prática / Tutorial / Sistema Hipermídia), qual software é mais fácil e qual é mais difícil de ser desenvolvido;

- se durante a produção do software existe uma interação entre a equipe de desenvolvimento e professores/especialistas com experiência em salas de aula e/ou pesquisa na área educacional, diretamente ligados à área específica do conteúdo abordado pelo produto;

- se (e de que forma) os Parâmetros Curriculares Nacionais são utilizados durante a produção dos softwares;

\footnotetext{
${ }^{10} \mathrm{http}: / /$ www.edsoft.futuro.usp.br/.

${ }^{11} \mathrm{O}$ questionário e a carta enviada podem ser encontrados em [Gladcheffo0g].
} 
- se os assuntos matemáticos são, geralmente, abordados separadamente ou de forma integrada.

Das vinte e oito empresas contatadas, uma nos explicou que já não produz mais software e sim metodologia para seu uso e, das restantes, apenas $29,6 \%$ responderam ao nosso questionário ${ }^{12}$. Portanto, fazemos agora, uma análise a partir dos dados informados por estas empresas colaboradoras. No total, temos uma empresa colaboradora de Belo Horizonte, uma de Campinas, uma de Recife, duas do Rio de Janeiro e três de São Paulo (incluindo Grande São Paulo). É preciso ressaltar que todas elas produzem softwares educacionais de Matemática direcionados ao Ensino Fundamental.

Duas empresas iniciaram a produção de softwares educacionais no final da década de 1980 e as seis restantes na década de 1990.

Sobre como surgiu o interesse por esse tipo de produção: para quatro empresas, pela verificação da falta de produtos considerados "adequados" no mercado; para uma, pela comercialização; para uma, através da verificação de que as aulas poderiam ser melhoradas com a utilização dessa ferramenta; para uma, a pedido de escolas conveniadas; e, para a última, a vontade de conciliar produção acadêmica com a atividade empresarial.

Os softwares de Matemática do tipo exercício e prática foram indicados, pela maioria, como os mais fáceis de serem elaborados, pelo fato de "não precisarem" utilizar muitos recursos gráficos. E a simulação foi indicada como a mais difícil de ser desenvolvida.

${ }^{12}$ Uma lista das empresas que responderam aos questionários pode ser encontrada em [Gladcheff00g]. 
A integração entre "técnicos em Informática" e "especialistas da área educacional" foi mencionada por todas as empresas e, uma delas colocou que para o desenvolvimento de seu projeto houve a participação de 26 profissionais, entre eles, pedagogos e professores.

Os PCN estão sendo colocados como orientadores no processo de desenvolvimento dos softwares educacionais de Matemática, exceto por uma empresa, sendo que, cinco já os utilizam e duas possuem esta preocupação mais recentemente.

E, por fim, sete empresas mencionaram que sempre tentam desenvolver os conteúdos matemáticos de forma integrada e, apenas uma, relatou que a maneira de trabalhar com estes conteúdos depende da faixa etária a que o produto se destina.

Podemos, dessa forma, perceber que as empresas, ou pelo menos algumas delas, estão começando a se preocupar com a qualidade pedagógica de seus produtos, tendo em vista um mercado cada vez mais competitivo e uma demanda cada vez mais crescente e crítica. Mas, não podemos esquecer que a produção de software educacional de alta qualidade técnica e sofisticada pedagogia é um grande desafio a todas elas. 


\section{Capítulo 4}

\section{A Metodologia de Pesquisa}

A seguir descrevemos a metodologia utilizada no desenvolvimento do trabalho.

Para expor precisamente sobre a qualidade do desenvolvimento de produtos e processos de software, é preciso que a qualidade seja descrita de forma quantitativa [Gresse96]. Mas isto é muito difícil para muitos aspectos de qualidade, como por exemplo, a usabilidade ou a modificabilidade do sistema. Um outro problema está na seleção das características relevantes dos produtos as quais descrevem um aspecto específico de qualidade pedido para um contexto particular.

Existem diferentes abordagens de medições e cada uma é apoiada por um conjunto de métricas apropriadas para a medição e interpretação dos dados no contexto dos objetivos [Gresse96]. Algumas delas são:

- Desenvolvimento da Função de Qualidade (Quality Function Development $Q F D)$, desenvolvida por Yoji Akao [Kogure83] [Gresse96], que oferece uma estrutura onde os aspectos de qualidade do produto final do ponto de vista do usuário podem ser considerados no planejamento, na engenharia e no controle do processo de desenvolvimento do software (é baseada na suposição de que características do produto final podem ser traçadas pelas características relatadas em produtos intermediários durante o processo de desenvolvimento do software);

- Métricas de Qualidade de Software (Software Quality Metrics - SQM), desenvolvida por Gerald E. Murine [Murine80] [Gresse96]. É baseada em uma abordagem que enfoca a quantificação dos fatores de qualidade de software propostos por McCall [McCall77]; 
- Objetivos/Questões/Métricas (Goal/Question/Metrics - GQM), um paradigma proposto por Victor Basili [Basili84], como uma abordagem orientada a objetivos, para a avaliação de produtos e processos na Engenharia de Software [Basili88], [Rombach91].

Essas abordagens concentram-se na relação das métricas para os objetivos de projeto do software. No entanto, diferem, significativamente, em termos do escopo da medição dos objetivos que cada uma auxilia, da orientação para a identificação das métricas relevantes e de seus potenciais usos.

A metodologia para derivação do instrumento de avaliação, "Questionário para Avaliação Geral da Qualidade do Produto de Software Educacional de Matemática Direcionado ao Ensino Fundamental", usada neste trabalho, foi a "Goal/Question/Metrics", já utilizada em muitos projetos de pesquisa em engenharia de software [Sanches93] e que atualmente vem sendo adotada em programas de avaliação de qualidade de software [Gresse] [Gresse96].

A principal característica da abordagem GQM é a sua capacidade de adaptação aos objetivos e particularidades do programa de avaliação a ser realizado, permitindo o aproveitamento das experiências obtidas, na melhoria de programas e projetos futuros [Kirner97] [Abib98]. Além disso, os objetivos dos programas de avaliação baseados na abordagem GQM podem ser aplicados em qualquer tipo de produto ou processo de software, dirigindo-se a todo tipo de propósito, ao alcance da caracterização e avaliação para controle e melhoria, concentrados em qualquer característica de qualidade e também definido através da perspectiva de interesse de qualquer pessoa em um ambiente específico. Esta abordagem auxilia na identificação das métricas relevantes, tão bem quanto suporta a análise e interpretação dos dados coletados. 
Uma descrição dessa abordagem se encontra na próxima seção (Seção 4.1).

Segundo Reiser [Reiser94], o conhecimento de especialistas da área educacional deve ser considerado em uma avaliação de software educativo, pois, só assim esta nova tendência de educação poderá enriquecer e favorecer o processo de aprendizagem. Para isto, utilizamos neste trabalho uma técnica de aquisição de conhecimento explícito.

Aquisição de Conhecimento inclui, segundo McGraw [McGraw89], todos os mecanismos para obtenção de informação a ser utilizada na modelagem de um domínio de conhecimento. Este conhecimento pode ser extraído de diversas fontes, tais como: especialistas humanos, livros, documentos, máquinas, etc. As técnicas de Aquisição de Conhecimento podem ser divididas em dois grandes grupos:

- Aquisição de Conhecimento Explícito ou Manual, onde a extração do conhecimento é realizada a partir de especialistas do domínio (algumas técnicas: Entrevista, Brainstorming, Análise de Protocolos, Rastreamento de Processo, Estudo de Casos, Introspecção, Repertório Grid, Análise de Tarefas); e,

- Aquisição de Conhecimento Implícito ou Automática, que objetiva extrair conhecimento de dados e/ou informações referentes ao domínio, através de sistemas de Aprendizado de Máquina (algumas técnicas: Aprendizado de máquina, Indução de regras).

Entende-se por "Conhecimento Explícito" toda e qualquer informação necessária para diferenciar e caracterizar um objeto de pesquisa, no caso de nosso trabalho, o software educacional. A abordagem de aquisição de conhecimento explícito teve origem na integração das Ciências Humanas, tais como Psicologia e Sociologia, nas quais se estuda o comportamento humano e técnicas de relacionamento interpessoal, com as técnicas de Inteligência Artificial, tais como representação de conhecimento e construção 
de base de conhecimento.

A técnica de aquisição de conhecimento explícito "Entrevista" pode ser considerada a mais comum para elicitação do conhecimento através de um especialista humano. De uma perspectiva de Aquisição de Conhecimento, há dois tipos básicos de entrevista: desestruturada e estruturada [McGraw89]. Cada uma pode ser aplicada de acordo com os objetivos da sessão. Uma entrevista desestruturada pode ser apropriada quando se deseja explorar um problema, ou melhor, durante os estágios iniciais da consideração de um tópico. Uma entrevista estruturada pode ser apropriada quando se desejam informações específicas do conteúdo e do problema, resultando em dados mais úteis para a Base de Conhecimento. A entrevista estruturada foi a técnica utilizada em nosso trabalho na extração de conhecimento dos especialistas da área educacional com uso do computador, envolvendo pedagogos, professores de Matemática, pedagogos com especialização em Informática e uma psicopedagoga.

A técnica "Entrevista" é descrita na Seção 4.2.

Como mencionado na Seção 2.1.2, a característica usabilidade pode ser considerada como a mais importante, tendo em vista o tipo específico do produto que estamos enfocando: o software educacional. Este aspecto do produto envolve alguns princípios que podem ser considerados difíceis de serem verificados apenas pelo professor. Por isso, propomos, neste trabalho, que o produto seja avaliado também por alguns alunos, no que diz respeito a esta característica. Para isso, o método da "Avaliação Heurística" foi aqui utilizado, com o objetivo de orientar o professor para a coordenação de uma avaliação da usabilidade da interface do produto de software, realizada por um conjunto de alunos. 
O método da "Avaliação Heurística" é o principal método elaborado. por Nielsen [Nielsen94] quando este propôs a denominada "engenharia econômica de usabilidade" baseada em métodos baratos, rápidos e fáceis de serem usados. Neste método Nielsen propõe um conjunto de heurísticas ou princípios de usabilidade, descritos na Seção 4.3.

As seções a seguir detalham as abordagens que subsidiam nosso método de pesquisa.

\section{IV.I A ABORDAGEM GQM}

A abordagem GQM foi originalmente proposta por Basili [Basili84], estendida e formalizada pelo mesmo, com a colaboração de Rombach e sua equipe [Basili95] [Gresse96]. Ela segue os princípios do paradigma de "Avaliação Orientada a Objetivos". Esta abordagem possui o objetivo de servir como uma metodologia genérica para orientar a elaboração e execução de programas de avaliação da qualidade de produtos e processos na área de Engenharia de Software.

A identificação clara e correta dos objetivos pretendidos, ou seja, "o que" se deseja avaliar, é o ponto de partida segundo o paradigma "Avaliação Orientada por Objetivos" [Gresse96]. Para que tais objetivos estejam bem definidos, é preciso que sejam detalhados em termos de:

Objeto de estudo : Qual é o objeto da tarefa de análise? (processo ou produto);

Propósito : Qual é o propósito da tarefa de análise? (determinar, caracterizar, entender, melhorar, motivar ou controlar algum aspecto de qualidade do objeto de medida);

Foco de qualidade : Qual aspecto de qualidade do objeto será analisado? (características de qualidade); 
Ponto de vista : De qual ponto de vista o foco de qualidade será analisado? (identificar a quem interessam os resultados da pesquisa: usuário, desenvolvedor, gerente de projeto, etc);

Ambiente : Em qual ambiente a avaliação será realizada? (fornece o contexto para as interpretações dos resultados).

Assim, toda a coleção de dados da avaliação deve ser baseada em objetivos específicos, que devem estar explicitamente documentados. Essa abordagem fornece um mecanismo que orienta a determinação dos objetivos de interesse da análise e o refinamento de cada objetivo em um conjunto de questões, com o propósito de quantificar os mesmos [Sanches93]. Tais questões definem o conjunto específico dos dados a serem coletados.

Segundo Gresse [Gresse] [Abib98], a abordagem GQM envolve: paradigma, modelo e método.

No paradigma GQM toda a coleção de dados em um programa de avaliação deve ser baseada em objetivos específicos explicitamente documentados. O paradigma GQM consiste na: determinação de um conjunto de objetivos de avaliação; aquisição de alguns modelos de qualidade; consideração do contexto no qual se irá aplicar a avaliação; elaboração de questões e derivação de métricas apropriadas, de acordo com o contexto e os objetivos da avaliação; validação e análise dos dados coletados; e, interpretação e armazenamento destes dados. 
Os componentes elementares do modelo GQM são:

- objetivo, que envolve cinco aspectos: objeto, propósito, foco de qualidade, ponto de vista e ambiente;

- as questões, que expressam a necessidade de se obter informações em uma linguagem natural cujas respostas devem estar de acordo com o objetivo e, para cada categoria de questão, uma ou mais questões podem ser formuladas;

- e as métricas, que especificam, em termos quantitativos e avaliáveis, as informações que se deseja obter durante as avaliações, sendo que uma ou mais métricas podem ser necessárias para cada questão.

O escopo do método GQM inclui: planejamento, execução do GQM e empacotamento das experiências obtidas durante este programa.

Os paradigmas "Avaliação Orientada por Objetivos" (que diz respeito à avaliação do produto) e "Melhoria da Qualidade" (que diz respeito à avaliação do processo), são incorporados ao longo do processo GQM que se divide em três etapas: Desenvolvimento do Plano GQM, Execução do Plano de Avaliação e Preparação dos Resultados. Estas etapas, por sua vez, são divididas em fases. As etapas e fases do processo de desenvolvimento da abordagem GQM são ilustradas na Figura 4.1.1. 


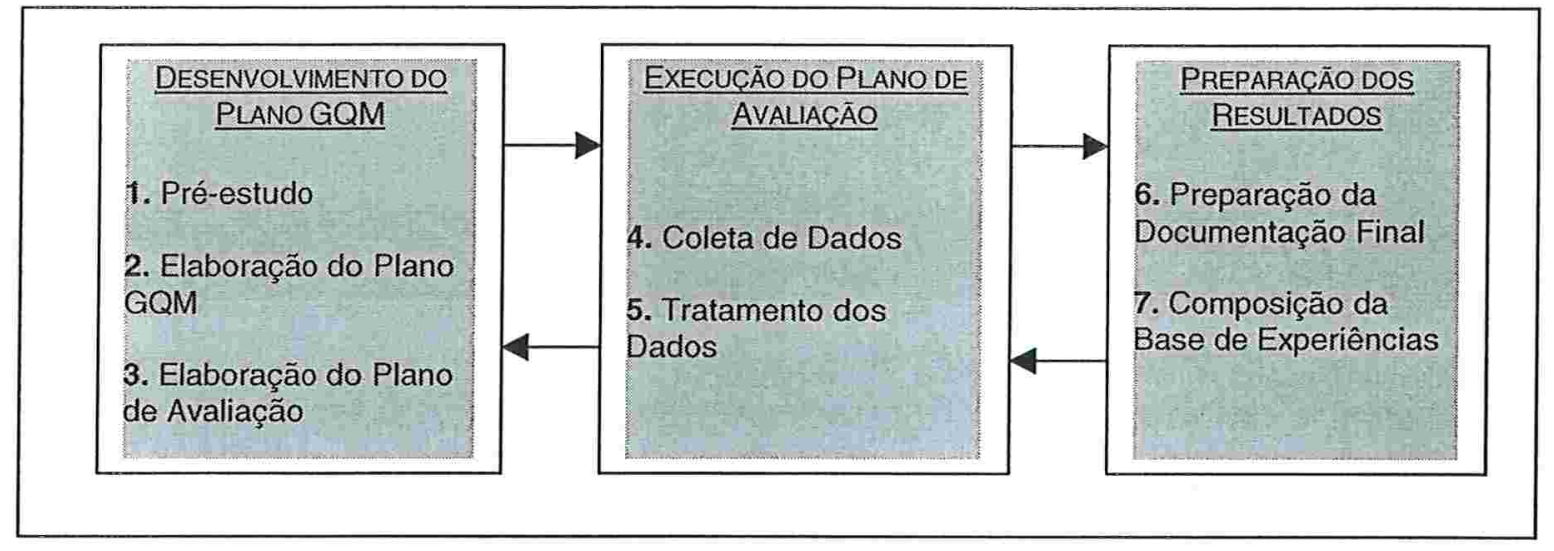

FIGURA 4.1.1 - ETAPAS E FASES DO PROCESSO GQM [ABIB98, PP.10]

O detalhamento de cada fase do processo é dado a seguir, nas seções 4.1.1, 4.1.2 e 4.1.3.

\section{IV.I.I Desenvolvimento do Plano GQM}

\section{FASE 1: PrÉ-Estudo}

O objetivo desta fase é a coleta de informações relevantes à introdução do programa de avaliação baseado na abordagem GQM.

Primeiramente, as pré-condições para a introdução do programa de avaliação são identificadas. Isto pode ser feito com base em documentos já existentes e também em experiências de avaliações anteriores realizadas em contextos similares, se possível. Além disso, a organização é caracterizada e os objetivos de melhoria são identificados (no caso de processo de software). 


\section{FASE 2: ELABORAÇÃo do PLANO GQM}

Esta fase divide-se em dois passos: identificação dos objetivos da avaliação GQM e preparação do plano GQM.

No passo de identificação dos objetivos da avaliação GQM, são apontados um ou mais objetivos a serem alcançados através da avaliação pretendida. Estes objetivos servirão de base para a elaboração do plano GQM e para o desenvolvimento do programa de avaliação, sendo que cada um deve ser detalhado através dos aspectos: objeto, propósito, foco de qualidade, ponto de vista e ambiente.

No passo de preparação, o desenvolvimento do plano GQM deve ser realizado de acordo com os objetivos identificados no passo anterior. Através de entrevistas ou questionários, o conhecimento das pessoas envolvidas na avaliação é adquirido, tomando-se o cuidado de as informações selecionadas serem compatíveis com os objetivos e ambiente definidos. Estas entrevistas são realizadas com pessoas pertencentes ao "ponto de vista" do objetivo da avaliação GQM. A informação obtida através das entrevistas é usada para formular focos de qualidade válidos e corretos. Baseado neste conhecimento, o objetivo da avaliação GQM é definido quantitativamente por um conjunto de métricas, formuladas através de questões no plano GQM. E então, o plano GQM é revisado para verificar se está correto e completo.

O resultado deste segundo passo da fase de elaboração do plano GQM é o plano GQM completo que contém:

- um objetivo definido com: objeto de estudo (processo ou produto), propósito (determinar, entender, melhorar, caracterizar, motivar ou controlar algum aspecto de qualidade do objeto de medida), foco de qualidade (características de qualidade), 
ponto de vista (identifica a quem interessa os resultados da pesquisa), e ambiente (fornece o contexto para as interpretações dos resultados);

- um conjunto de questões, para caracterizar um objeto de pesquisa e os aspectos de qualidade do mesmo; e,

- um conjunto de métricas associadas às questões, que visam respondê-las de um modo quantitativo.

\section{P FASE 3: ElaboraçÃo do Plano de Avaliação}

O objetivo desta fase é a integração apropriada da avaliação/medição dentro do processo do software.

Primeiro, uma lista de métricas de todos os planos GQM do programa de avaliação é formulada (O quê?). Então, para cada métrica, identifica-se quando o dado da avaliação pode ser coletado (Quando?). Também, para cada métrica, identifica-se quem pode, possivelmente, fornecer os dados (Quem?). E o passo seguinte é especificar os procedimentos da coleta de dados (Como?).

O resultado obtido nesta fase é o plano de avaliação integrado ao processo do software, com a especificação do que será realizado durante a avaliação, de como os dados serão coletados, quem fornecerá estes dados e quando a avaliação será realizada.

\section{IV.I.II Execução do Plano de Avaliação}

\section{FASE 4: ColetA DE DADOS}

O objetivo desta fase é conseguir os dados necessários para uma avaliação, em relação ao objetivo especificado. Os dados são coletados através do preenchimento do 
questionário e devem ser validados através da verificação dos formulários quanto a não ocorrência de erros, consistência e completude. Desta forma, no mínimo os seguintes pontos devem ser checados, quanto às propriedades dos dados:

- legibilidade: verificar se as respostas são legíveis. (Este ponto é somente relevante para as folhas de coleta preenchidas a mão);

- completude: verificar se existe alguma questão omissa que deve ser respondida;

- corretude: verificar se muitas opções foram marcadas, em questões de múltiplas escolhas, onde só é permitido marcar apenas uma opção;

- plausibilidade: verificar se os valores estão no tipo correto, ou seja, inteiro, decimal, texto, etc, e se se encontram num campo válido.

O resultado, que se obtém com esta fase, são os dados necessários coletados e validados, para serem utilizados na fase seguinte.

\section{- FASE 5: TRATAMEnto dos Dados}

Nesta fase é feita a análise e a interpretação dos dados para que as informações obtidas durante a coleta sejam utilizadas de acordo com o objetivo da avaliação. Assim, os dados são analisados e interpretados no contexto das questões desenvolvidas na preparação do plano GQM com as quais estão eles associados.

\section{IV.I.III Preparação dos Resultados}

\section{Fase 6: Preparação da Documentação Final}

O objetivo desta fase é a elaboração de um documento final com todos os dados coletados durante a avaliação. 
Os resultados das experiências adquiridas pelo programa de avaliação em relação ao produto/processo de software enfocado, assim como o próprio programa de avaliação, são analisados e documentados.

\section{FASE 7: COMPOSIÇÃO DA BASE DE EXPERIÊNCIAS}

O objetivo desta fase é armazenar as experiências adquiridas no programa de avaliação, para reutilizar este conhecimento em projetos de software e programas de avaliação futuros.

As experiências em relação aos processos/produtos de software adquiridas através do programa de avaliação podem ser armazenadas com o processo de desenvolvimento de software. Cada experiência armazenada deve ser associada a um ambiente, dentro do qual as lições aprendidas e/ou modelos são válidos e podem ser aplicados.

Ao final desta fase, o plano de avaliação se encerra e os dados coletados durante a avaliação estão validados, analisados, interpretados e armazenados em uma base de dados para posteriores consultas.

\section{IV.II A TÉCNICA de ENTREVISTA PARA AquisiçÃo de CONHECIMENTo EXPlícito}

Gammack e Young [Gammack85] [McGraw89], dizem que a entrevista é a técnica mais usada por Engenheiros de Conhecimento para elicitar o conhecimento de um Especialista do Domínio, pois permite que o Engenheiro de Conhecimento compreenda rapidamente conceitos e vocabulário importantes no domínio.

A entrevista pode parecer uma técnica primária e ineficiente de Aquisição de Conhecimento. Diz-se também, que a entrevista informal pode não ser uma introdução 
apropriada para a Aquisição de Conhecimento no domínio, mas se for implementada uma estratégia estruturada, ela pode ser considerada uma ferramenta muito eficiente.

Como já mencionado, existem dois tipos de entrevista: desestruturada e estruturada. As entrevistas desestruturadas raramente proporcionam descrições completas, ou bem organizadas, de processos cognitivos. Neste tipo de entrevista, o Engenheiro de Conhecimento pode realizar questões espontâneas. Já a entrevista estruturada força uma organização entre o Engenheiro de Conhecimento e o Especialista do Domínio. Ao contrário da informalidade presente na entrevista desestruturada, a entrevista estruturada é objetivamente orientada. Uma razão pela qual a entrevista estruturada é mais efetiva, é que ela força o Especialista do Domínio a ser sistemático ao aplicar-se às suas tarefas. O estudo sobre a técnica da entrevista estruturada, apresentado a seguir, está baseado em McGraw [McGraw89].

As sessões da entrevista estruturada possuem cinco fases: planejamento, começo, corpo, fechamento e follow up, ou seja, após o término da entrevista.

\section{a FASE 1: Planejamento dA ENTREVISTA}

$\mathrm{Na}$ fase do planejamento, uma vez que os tópicos foram selecionados, uma agenda e exemplos de questões a serem utilizadas durante a entrevista devem ser desenvolvidos. As questões a serem utilizadas podem ser classificadas de diversas formas. Uma das mais comuns as classifica como: abertas (não são seguidas por alternativas; elas encorajam a resposta livre) e, fechadas (determinam limites para o tipo, nível e quantidade de informações que o Especialista do Domínio fornece). É imperativo que seja decidido antes da entrevista qual o processo que será utilizado para a anotação das informações. O Especialista do Domínio deve ser comunicado com antecedência, sobre a 
metodologia a ser utilizada para a anotação. As anotações podem ser feitas manualmente ou gravadas. As ferramentas (papel, gravador, filmadora, ...) necessárias, assim como as que podem ser utilizadas como suporte nas sessões, devem estar preparadas.

\section{FASE 2: COMEÇO DA ENTREVISTA}

Uma fase crítica de qualquer entrevista é a introdução ou abertura. A principal função desta fase é motivar os participantes a uma comunicação ativa. O que um entrevistador diz e faz durante esta fase dá o "tom" para o que segue. O "tom" transmitido deve ser compreendido como profissional, não ameaçador e "relaxante". De outra forma poderia desencorajar a participação honesta e livre do Especialista do Domínio na sessão, ou mesmo a participação em entrevistas subseqüentes.

\section{P FASE 3: CORPO DA ENTREVISTA}

O formulário de Aquisição de Conhecimento exposto na Figura 4.2.1 pode servir como um guia para o corpo ou parte principal de uma sessão.

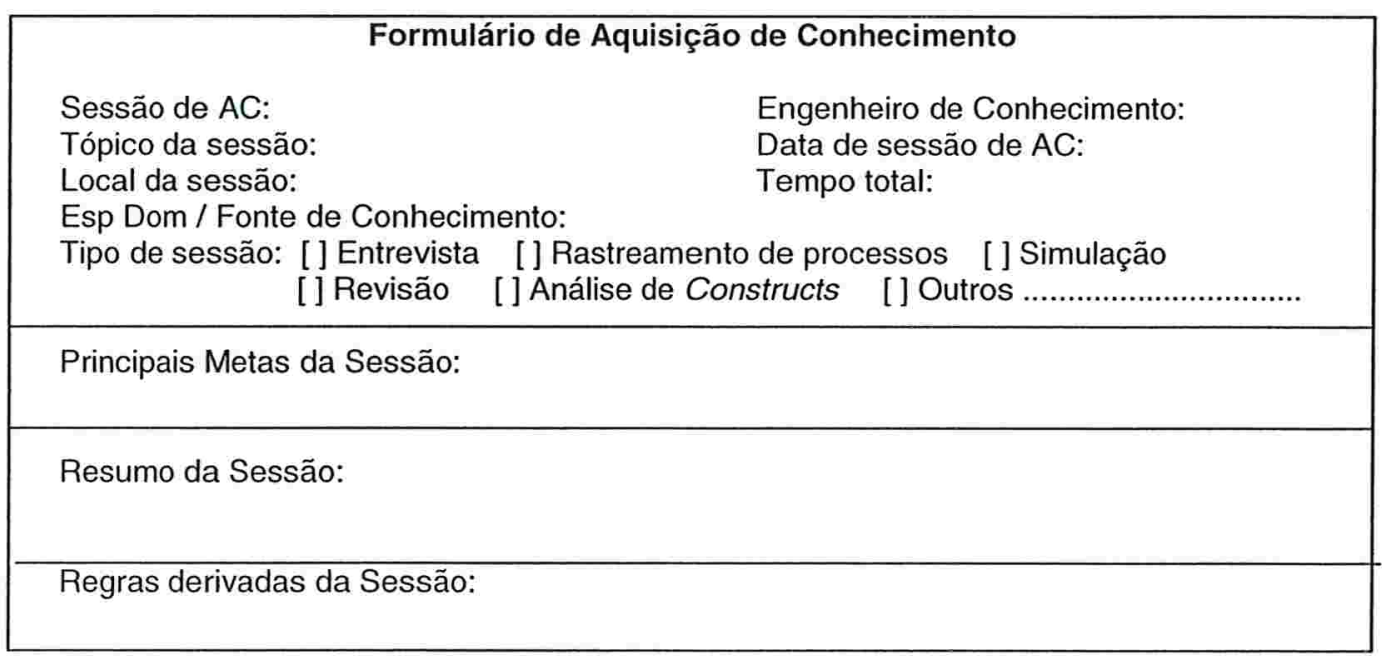

FiguRA 4.2.1 - FoRMULÁRIO DE AQUISIÇÃO DE CONHECIMENTO [MCGRAW89, PP.80] 
O mais importante é que o formulário induz a áreas planejadas a serem cobertas, ao contrário de perguntas aleatórias que podem não proporcionar investigações adequadas em um tópico ou área.

A comunicação verbal é a forma mais aberta pelo qual o significado é transmitido durante a entrevista. A maneira pela qual a mensagem verbal é compreendida depende, em parte, da similaridade de backgrounds, vocabulários e experiências dos comunicadores. Mas textos de comunicação, em geral, concordam que um entrevistador transmite certas mensagens não verbais durante uma entrevista. Por exemplo, fala rápida pode indicar importância ou urgência, voz sussurrada pode transmitir nervosismo e fala que vacila pode indicar incerteza. Com isto, é preciso que um feedback seja feito, pois é no "dar e receber" que o Engenheiro de Conhecimento recebe, entende e comunica se o entendimento ocorreu. Este feedback deve ser contínuo e imediato. Em geral, pode ser realizado de três formas: verificação ("Sim, eu disse exatamente isso"), discordância ("Não, eu não disse isso"), e revisão ("De fato, o que eu quero dizer é ..."). Mas o feedback deve ser evitado para todo comentário feito pelo Especialista do Domínio, pois deve ser utilizado apenas para clarear frases/idéias, quando necessário.

Após uma hora de sessão com concentração intensa e escrita ativa, o Engenheiro de Conhecimento pode ficar induzido a cortar as atividades de fechamento da entrevista. Observações a videotapes com sessões de Aquisição de Conhecimento indicam que esta é uma tendência comum.

\section{P FASE 4: FECHAMENTO DA ENTREVISTA}

O fechamento da entrevista é uma parte importante da sessão. Pesquisas na área de Psicologia revelam que as pessoas possuem a tendência de se lembrar do que ocorre 
primeiro em uma interação, ou seja, as primeiras impressões. E as pessoas possuem, também, a tendência de julgar uma interação baseadas no que ocorre por último [McGraw89].

Se o Engenheiro de Conhecimento faz um bom trabalho resumindo os pontos principais e os propósitos da sessão de Aquisição de Conhecimento, provê a oportunidade ao Especialista do Domínio de clarear ou revisar estes pontos. Pode, com isto, aproveitar para dizer o que espera a seguir. É bem provável que o Engenheiro de Conhecimento deixe ao Especialista do Domínio a impressão de que o tempo foi bem "gasto". Desta forma, a tendência dos especialistas é se sentirem a vontade para participar das próximas sessões e, provavelmente, elogiarão o trabalho do Engenheiro de Conhecimento junto a outros especialistas.

Algumas técnicas verbais e não verbais podem ser utilizadas para o fechamento de uma entrevista. Muitos entrevistadores combinam signos verbais e não verbais. A adaptação e resumo de algumas das técnicas de fechamento verbal para uma sessão de Aquisição de Conhecimento, são mostradas na Figura 4.2.2.

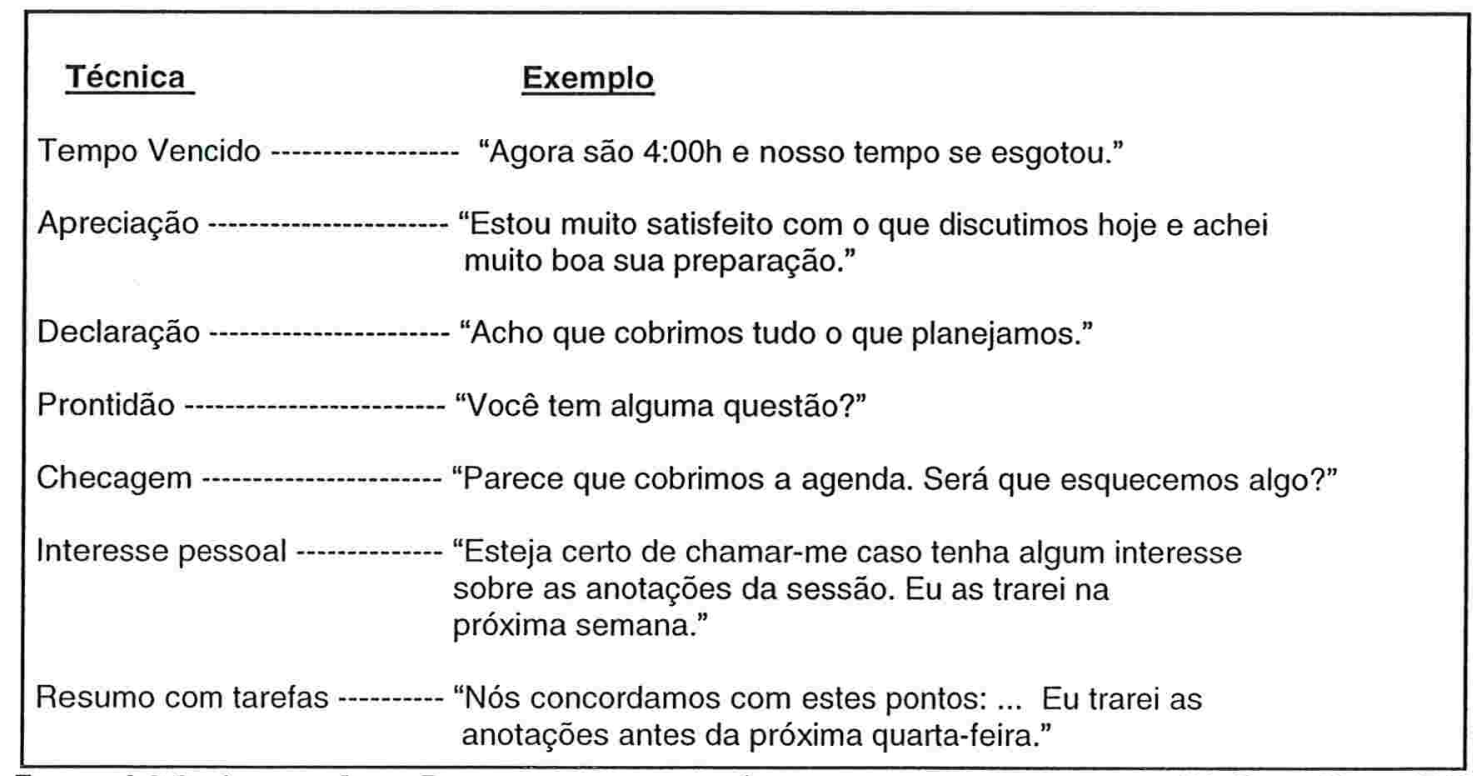

FIGURA 4.2.2 - AdAPTAÇōES E RESUMOS DE ALGUMAS TÉCNICAS DE FECHAMENTO VERBAL [MCGRAW89, PP.197] 


\section{P FASE 5: FolLOW UP / APÓS O TÉRMINO DA ENTREVISTA}

Quando a entrevista acaba, o Engenheiro de Conhecimento entra na fase em que deve traduzir as informações obtidas em um formato útil. Esta fase é chamada de "follow up". É preciso que as informações das sessões sejam transcritas e também deve ser decido o que é importante.

$\mathrm{Na}$ tarefa de transcrição das informações, é preciso que seja decidido antecipadamente se as fitas da sessão serão totalmente transcritas ou se a transcrição será apenas dos pontos mais importantes. Porém, decidir o que é realmente importante não é uma tarefa trivial. A fita gravada é obtida para propósitos de arquivo, porém, as anotações são utilizadas para resumir e indexar as informações para facilitar o acesso.

\section{IV.III O MÉtodo da "Avaliação Heurística"}

A avaliação heurística é a realização de uma inspeção sistemática da interface a fim de identificar problemas de usabilidade, tomando como base um conjunto de heurísticas ou princípios de usabilidade. Esta avaliação, de acordo com indicadores de experiências de maior sucesso, pode ser conduzida por um pequeno conjunto de avaliadores, em torno de três a cinco pessoas [Rocha00].

As heurísticas, apresentadas na Tabela 4.3.1, são regras gerais que objetivam descrever propriedades comuns de interfaces usáveis [Nielsen94]. Adicionalmente ao conjunto de heurísticas gerais, pode-se, também, considerar heurísticas específicas de acordo com a categoria do produto que está sendo avaliado.

O método de avaliação heurística inicia-se com cada avaliador percorrendo a interface por diversas vezes, procurando detectar uma lista de problemas, através das 
heurísticas de usabilidade, que possam, pelo ponto de vista do avaliador, estar violando algum ou alguns dos princípios associados.

Após as listas de problemas de cada avaliador terem sido geradas, a segunda etapa do método é consolidá-las em uma única lista. Os avaliadores discutem em conjunto e geram uma única lista de problemas de usabilidade.

A etapa seguinte do método se dá com a avaliação da gravidade de cada problema detectado. Esta gravidade é a combinação de três fatores: freqüência com que o problema ocorre (se é comum ou raro); impacto do problema quando ocorre (se é fácil ou difícil de o usuário superá-lo) e persistência do problema (se ocorre uma vez e o usuário o supera ou se os usuários serão repetidamente incomodados por ele). E, por fim, é considerado o impacto do problema no mercado, pois muitos problemas simples de serem superados possuem um efeito importante na popularidade de um produto.

Desta forma, ao final, obtém-se uma lista dos problemas identificados pelos avaliadores, ordenados de acordo com a gravidade de cada um, em conjunto com seu grau de severidade (impacto do problema no mercado).

Alguns exemplos de problemas de usabilidade detectados através da Avaliação Heurística podem ser encontrados em Rocha [Rocha00]. 


\begin{tabular}{|c|c|}
\hline Heurística & Descrição \\
\hline 1. Visibilidade sobre o estado do sistema & $\begin{array}{l}\text { É preciso que o sistema mantenha os usuários } \\
\text { informados durante as atividades, fornecendo retorno } \\
\text { adequado dentro de um tempo razoável. }\end{array}$ \\
\hline 2. Relação entre o sistema e o mundo real & $\begin{array}{l}\text { O sistema deve falar a linguagem do usuário, } \\
\text { utilizando palavras, frases e conceitos familiares, ao invés } \\
\text { de termos orientados ao sistema. Deve seguir convenções } \\
\text { do mundo real, fazendo com que a informação apareça } \\
\text { numa ordem natural e lógica. }\end{array}$ \\
\hline 3. Controle do usuário e liberdade & $\begin{array}{l}\text { Os usuários geralmente escolhem erroneamente } \\
\text { funçōes do sistema, portanto, é necessário que existam } \\
\text { saídas claras de emergência, fazendo com que o usuário } \\
\text { deixe o estado não desejado sem que o fluxo do diálogo e } \\
\text { sua continuidade sejam prejudicados. O sistema deve } \\
\text { tratar o "desfazer" e o "refazer". }\end{array}$ \\
\hline 4. Consistência e padrões & $\begin{array}{l}\text { Os usuários não devem ser surpreendidos com } \\
\text { diferentes palavras, situações ou ações que possuam o } \\
\text { mesmo significado. }\end{array}$ \\
\hline 5. Prevenção de erros & $\begin{array}{l}\text { Melhor que uma boa mensagem de erro é um } \\
\text { projeto cuidadoso, que previna problemas, antes mesmo } \\
\text { de ocorrerem. }\end{array}$ \\
\hline $\begin{array}{l}\text { 6. Reconhecimento ao invés da } \\
\text { recorrência à memória do usuário }\end{array}$ & $\begin{array}{l}\text { O sistema deve possuir objetos, ações e opções de } \\
\text { forma visível. Ele não deve obrigar o usuário a relembrar } \\
\text { informações da parte de um diálogo para outro. As } \\
\text { instruções para uso do sistema devem estar visíveis ou } \\
\text { dispostas de forma apropriada para fácil reconhecimento e } \\
\text { recuperação quando necessário. }\end{array}$ \\
\hline $\begin{array}{l}\text { 7. Flexibilidade e eficiência de uso do } \\
\text { sistema }\end{array}$ & $\begin{array}{l}\text { O sistema deve, também, fornecer aceleradores, } \\
\text { desconhecidos pelos usuários novatos, a fim de que seja } \\
\text { facilitada a interação para um usuário mais experiente, } \\
\text { com isto favorecendo ambas as categorias. Deve-se } \\
\text { permitir que usuários experientes possam "cortar } \\
\text { caminhos" em ações freqüentes. }\end{array}$ \\
\hline 8. Simplicidade e estética do sistema & $\begin{array}{l}\text { Diálogos não devem conter informações } \\
\text { irrelevantes ou raramente necessárias. Toda unidade extra } \\
\text { de informação em um diálogo concorre com unidades } \\
\text { relevantes e diminuem sua visibilidade relativa. }\end{array}$ \\
\hline 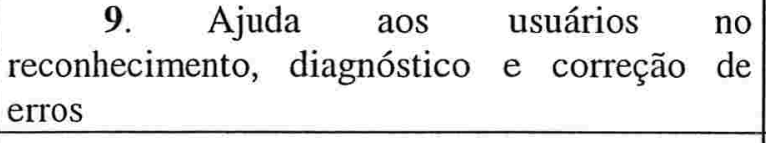 & $\begin{array}{l}\text { Mensagens de erro devem ser expressas em } \\
\text { linguagem clara (sem códigos), indicando precisamente o } \\
\text { problema e sugerindo, construtivamente, uma solução. }\end{array}$ \\
\hline 10. Documentação e ajuda aos usuários & $\begin{array}{l}\text { O melhor seria que o sistema fosse utilizado sem } \\
\text { que o usuário precisasse recorrer à documentação ou ao } \\
\text { help. Mesmo assim, é necessário que o sistema possua } \\
\text { uma documentação a fim de que o usuário seja auxiliado. } \\
\text { Estes recursos devem ser de fácil acesso e elaborados em } \\
\text { função das tarefas típicas do usuário, listando passos } \\
\text { concretos a serem percorridos, e não muito extensos. }\end{array}$ \\
\hline
\end{tabular}

TABELA 4.3.1 - CONJUNTO DE HEURISTICAS DE USABILIDADE [Nielsen94, pp.30] 
A relação dos atributos de usabilidade citados na Seção 2.1.1 com as heurísticas expressas por Nielsen, é apresentada na Tabela 4.3.2. Cada atributo de usabilidade pode ser avaliado segundo as heurísticas relacionadas na mesma tabela.

\begin{tabular}{||c||l||}
\hline Atributo & Heurísticas nro \\
\hline \hline Facilidade de aprendizado & $2-3-4-6$ \\
$8-9-10$
\end{tabular}

TABELA 4.3.2 - RELAÇÃO dOS ATRIBUTOS DE USABILIDADE COM AS HEURISTICAS

A Tabela 4.3.3 mostra as heurísticas que serão utilizadas para avaliar a característica usabilidade do produto de software educacional de Matemática, direcionado ao Ensino Fundamental, em cada forma de avaliação. São elas, a "Avaliação Geral do Produto de Software Educacional" realizada, apenas, pelo professor ou pelo especialista da área educacional e a "Avaliação Heurística" realizada por alguns alunos e dirigida pelo professor ou especialista da área educacional. 


\begin{tabular}{||l||l||}
\hline Forma de Avaliação & Heurísticas compreendidas nro \\
\hline \hline $\begin{array}{c}\text { Avaliação Geral do Produto de Software } \\
\text { Educacional de Matemática direcionado ao Ensino } \\
\text { Fundamental prealizada pelo professor ou } \\
\text { especialista da área educacional) }\end{array}$ & $6-2-3-4-5$ \\
\hline $\begin{array}{c}\text { Avaliação da Usabilidade da Interface } \\
\text { (realizada por alguns alunos e dirigida pelo professor } \\
\text { ou especialista da área educacional) }\end{array}$ & $2-3-6$ \\
\hline
\end{tabular}

TABELA 4.3.3 - HEURISTICAS UTILIZADAS NA AVALIAÇÃO DA CARACTERISTICA USABILIDADE 


\section{Capítulo 5}

\section{DesenVolvimento do Trabalho}

No contexto deste trabalho foram aplicadas partes do método GQM (descrito na Seção 4.1) por três vezes distintas. Na primeira, o objetivo principal foi obter informações sobre quais das características de qualidade descritas na Norma ISO/IEC 9126-1 são necessárias de verificação em um software educacional de Matemática do Ensino Fundamental e, também, adquirir conhecimento através de especialistas da área educacional sobre aspectos ligados ao processo ensino-aprendizagem que devem estar presentes no software. Na segunda, os objetivos foram verificar a qualidade de softwares educacionais de Matemática do Ensino Fundamental e obter feedback inicial sobre o instrumento de avaliação. Na terceira avaliar a característica usabilidade do software, do ponto de vista do usuário final (o aluno).

A seguir descrevemos as fases realizadas nas três aplicações do método GQM.

\section{V.I Primeira Utilização do MÉtodo GQM - obTençÃo de conhecimento JUNTO A ESPECIALISTAS}

\section{$\rightarrow$ ETAPA: Desenvolvimento do PLANo GQM}

\section{Fase 1: Pré-Estudo}

Foi identificada literatura referente à Educação, Informática na Educação e Modalidades de softwares educacionais. Alguns trabalhos: [Barbeiro99], [Braga96], [Campos94a], [Campos99a], [Carraher90], [Chaves88], [CSR98], [Dantas00], [Faerman99], [Frant98], [Gadotti94], [Joly95], [Leite96], [Lima96], [Magina98], 
[McGraw89], [Moretto99], [Oliveira84], [Oliveira96], [Papert85], [PCN97a], [PCN97b], [PCN97c], [Tarouco99], [Valente91], [Valente93].

\section{Fase 2: Elaboração do Plano GQM}

O objetivo foi detalhado nos termos seguintes:

Objeto de estudo: produto de software educacional de Matemática do Ensino Fundamental.

Propósito: extrair conhecimento de especialistas da área educacional sobre as partes pedagógica, lúdica, psicopedagógica, sócio-cognitiva e cultural do objeto.

Foco de qualidade: características pedagógicas, lúdicas, psicopedagógicas e culturais.

Ponto de vista: especialistas da área educacional.

Ambiente: CAEM/USP (Centro de Aperfeiçoamento de Ensino de Matemática), FE/USP (Faculdade de Educação) e Laboratório de Ciências da Cognição/Universidade Metodista de São Paulo.

O conjunto de questões elaborado nesta fase diz respeito ao que foi respondido pelos especialistas, através da Técnica de Aquisição de Conhecimento "entrevista" (descrita na Seção 4.2). As questões foram do tipo "abertas". Com isto, os especialistas ficaram à vontade para expor o conhecimento que possuem sobre o domínio. Cada questionário foi direcionado diretamente à especialidade do entrevistado. 


\section{Fase 3: Elaboração do Plano de Avaliação}

O planejamento para as entrevistas foi elaborado especificando "quando", "como" e "por quem" as questões levantadas na fase anterior seriam respondidas.

Um formulário de Aquisição de Conhecimento, conforme a Figura 4.2.1, foi elaborado para cada um dos especialistas. Nesse formulário havia também especificações a respeito do processo que seria utilizado para a anotação das informações durante a entrevista (neste caso, um pequeno gravador) e uma descrição dos tipos de software contemplados no instrumento de avaliação gerado. Esses formulários foram entregues aos especialistas em média com quatro dias de antecedência a cada entrevista.

\section{$\rightarrow$ ETAPA: Execução do Plano de Avaliação}

\section{Fase 4: Coleta de Dados}

Os dados foram coletados através da realização das entrevistas, ou seja, as questões elaboradas na fase 2 foram respondidas por sete especialistas da área educacional. São eles:

- psicopedagoga com experiência em Informática na educação (Doutora em Psicologia Escolar pela USP. Professora Titular do Departamento de Psicologia da Saúde, da Universidade Metodista de São Paulo - Laboratório de Ciências da Cognição. Coordenadora da PRIMAX - Centro de Aprendizagem e Informática. Psicóloga Clínica Infantil e Orientadora de pais. Autora de livros e artigos sobre Psicologia Infantil, Avaliação Psicopedagógica e Informática em Psicopedagogia); 
- professor de Matemática do Ensino Fundamental, responsável pelo laboratório de Informática na escola (Professor de Ensino Fundamental e ensino médio, licenciado em Matemática pelo IME/USP, bacharel em Matemática pela faculdade de Filosofia, Ciências e Letras de Santo André. Atualmente leciona Matemática na Escola de Aplicação da FE-USP);

- professora de Matemática do Ensino Fundamental, responsável pelo laboratório de Informática na escola (Leciona há 23 anos no Ensino Fundamental, ministrando aulas de Matemática e Ciências. Utiliza o computador nas aulas há cerca de 10 anos, mais intensamente, há 5 anos, na Escola de Aplicação da FE-USP);

- professora de Matemática do Ensino Fundamental, pesquisadora no CAEM-USP (Licenciada e Bacharel em Matemática pela USP. Fez especialização em Análise de Sistemas pela Fundação Santo André. Fez pósgraduação em Psicologia da Educação (lato sensu). Mestre em Didática pela FE/USP e Doutora em Linguagem pela FE/USP. Foi professora de Matemática no Ensino Fundamental na Escola de Aplicação da FE/USP e coordenadora do laboratório de Informática da escola);

- pedagoga com especialização em Informática (Pedagoga pela PUC/SP e especialista em Informática pela UFPA com atuação no campo da Informática educativa. Atualmente trabalha como Supervisora Escolar na DREM3 - Delegacia Regional de Ensino Municipal - da PMSP);

- pedagoga com especialização em Informática (Pedagoga, Mestre em Tecnologia da Educação. Atua há 12 anos no Senai/SP como membro da equipe de Educação a distância, desenvolvendo projetos e recursos didáticos para a formação profissional);

- professor universitário (Professor assistente doutor no IME-USP. Responsável pelo LEM-USP - Laboratório de Ensino de Matemática e pela disciplina Noções de Matemática Usando o Computador, ministrada no curso de licenciatura em Matemática). 


\section{EXPERIÊNCIA OBTIDA COM ESTA ATIVIDADE:}

A prévia organização das entrevistas mostrou ser imprescindível para um melhor aproveitamento do tempo disponibilizado pelos especialistas. Confirmando este fato, os próprios entrevistados ressaltaram a importância do formulário entregue antecipadamente às entrevistas. Com este material, eles puderam se preparar de tal forma a serem o mais objetivo possível durante os questionamentos. A maioria, inclusive, utilizou anotações próprias desenvolvidas mediante os pontos abordados no formulário.

A disposição demonstrada por estes pesquisadores em nos atender nos mostra que os conhecimentos que detêm é proporcional a "empolgação" dos mesmos em relatá-los.

Pelo dinamismo das entrevistas, pudemos observar que o equipamento utilizado (gravador) não inibiu os especialistas a manifestarem seus pontos de vista. Com as gravações das sessões de Aquisição de Conhecimento, foi possível gerenciarmos o processo das entrevistas livremente, sem a necessidade de fazermos anotações manuais durante cada sessão.

Ressaltamos que a riqueza das informações, experiências e orientações colhidas nestas entrevistas deram um importante suporte à elaboração do instrumento gerado com este trabalho.

Durante a realização das entrevistas, a convergência dos conceitos e opiniões sobre os temas abordados, levou-nos a interpretar que o número de especialistas entrevistados (sete) atendia fortemente os requisitos traçados para esta atividade. Assim, entendemos que se aumentássemos este número, as informações diferenciadas agregadas seriam poucas.

A entrevista realizada com a psicopedagoga Prof.a Dr.a Vera Barbos de Oliveira, gerou um artigo que foi aceito pela "Revista Brasileira de Informática na Educação", a ser publicado em abril de 2001, em sua edição nro 8. O título é "O Software Educacional e a Psicopedagogia no Ensino de Matemática Direcionado ao Ensino 
Fundamental". O seu texto completo também pode ser encontrado nas páginas de nosso projeto na Web [Gladcheffo0g].

\section{Fase 5: Tratamento dos Dados}

Os dados obtidos através dos especialistas foram analisados e interpretados. O processo utilizado para anotação das informações foi a gravação. Portanto, nesta fase, as entrevistas foram transcritas na íntegra e depois editadas. O texto completo de cada uma delas pode ser encontrado em [Gladcheffo0g].

\section{Etapa: Preparação dos Resultados}

\section{Fase 6: Preparação da Documentação Final}

Uma listagem com todos os dados coletados foi elaborada de tal forma a sintetizar as informações necessárias ao desenvolvimento do instrumento/questionário de avaliação.

Após o término desta primeira utilização do método GQM, 28 produtores de software de Matemática no Brasil foram identificados e contatados para que respondessem a um questionário elaborado por nós. Foram feitas questões que abordam a forma de desenvolvimento de seus softwares educacionais, em especial, de Matemática do Ensino Fundamental, como mencionado na Seção 3.7.

Apenas $29,6 \%$ dos produtores responderam ao nosso questionário. Uma relação deles assim como o questionário entregue, podem ser encontrados em [Gladcheff00g]. Estas informações são discutidas na Seção 3.7. 
A Figura 5.1.1, apresentada a seguir, representa o esquema resumido das atividades realizadas durante a "Primeira Utilização do Método GQM".

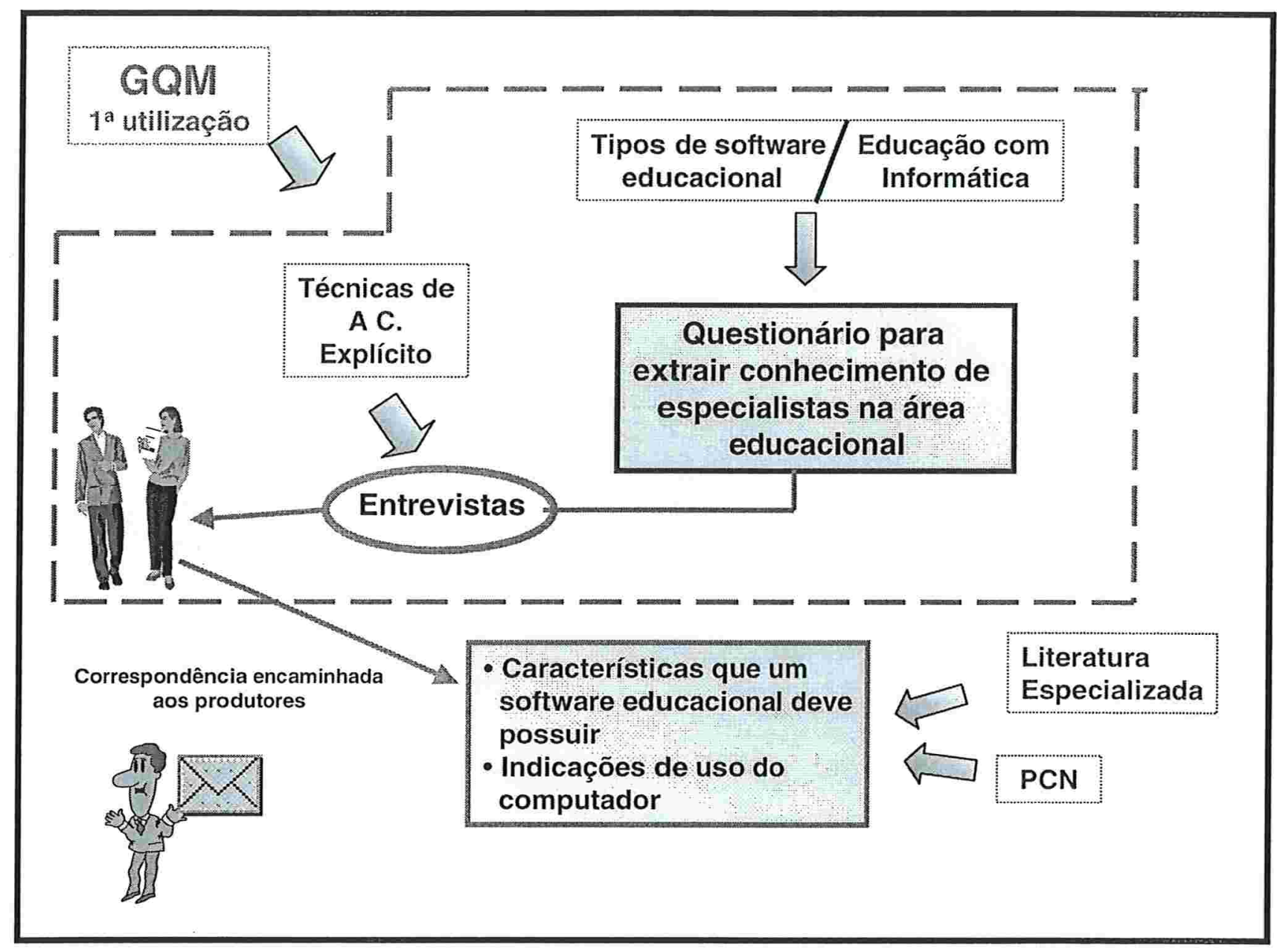

Figura 5.1.1 - Esquema Resumido das Atividades Realizadas DuRANTE a $1^{A}$ Utilizaçāo do MÉtodo GQM 


\section{V.II SEGUNDA UtILIZAÇÃo DO MÉTOdo GQM - ELABORAÇÃo DO QUESTIONÁRIO PARA AVALIAÇÃO E FEEDBACK}

$\Rightarrow$ ETAPA: DesenVolvimento do Plano GQM

\section{Fase 1: Pré-Estudo}

A introdução do programa de avaliação foi baseada na documentação final elaborada na primeira utilização do método GQM, nas Normas ISO/IEC 9126-1 e ISO/IEC 12119, no método para avaliação da qualidade da Fundação Centro Tecnológico para Informática "MEDE-PROS ${ }^{\circledR \text { " }}$ [CTI00], na proposta do conjunto mínimo de características pedagógicas de Campos F. [Campos99b], na tese de doutorado de Campos G. [Campos94b], nas dissertações de mestrado de Cristovão [Cristovão97a] e Loureiro [Loureiro98], nos atributos de usabilidade de Nielsen [Rocha00], nas heurísticas de usabilidade propostas por Nielsen [Nielsen94] e em artigos referentes à avaliação da qualidade de software educacional, tais como [Oliveira87] e [Vieira00], entre outros.

\section{Fase 2: Elaboração do Plano GQM}

O objetivo foi detalhado nos termos seguintes:

Objetos de estudo: produto de software educacional de Matemática do Ensino Fundamental e o instrumento de avaliação gerado.

Propósitos: verificar a qualidade do software educacional e obter feedback inicial sobre o instrumento de avaliação. 
Foco de qualidade: características técnicas, pedagógicas, lúdicas, psicopedagógicas e culturais.

Ponto de vista: professores de Matemática e orientadores pedagógicos.

Ambiente: ensino-aprendizagem de Matemática apoiado por ferramentas computacionais.

Foram elaborados dois conjuntos de questões: um para compor o instrumento de avaliação com base nos dados obtidos através da primeira utilização do método GQM e outro para a avaliação do instrumento em si, ou seja, um questionário de julgamento para o instrumento de avaliação gerado.

A gradação (número de níveis) utilizada para as respostas (métricas) aos questionamentos do instrumento, foi baseada em uma experiência com avaliação da qualidade de softwares. Esta experiência se deu através da participação no processo de avaliação para o prêmio ASSESPRO de melhor software do ano de 1996, coma utilização do método para avaliação da qualidade de software, "MEDEPROS $^{\circledR}$, da Fundação Centro Tecnológico para Informática [CTI00].

Sob o ponto de vista dos especialistas, aspectos de funcionalidade e usabilidade do software educacional podem ser indicados como os mais relevantes para este tipo específico de produto. Mas, é preciso ressaltar que aspectos de confiabilidade, eficiência, portabilidade (no que diz respeito à facilidade de instalação do produto) e manutenibilidade (no que diz respeito a indicações feitas pelo produtor), também foram incluídos no instrumento de avaliação gerado, a fim de que também sejam analisados no produto. 


\section{Fase 3: Elaboração do Plano de Avaliação}

Foram elaborados dois planos de avaliação:

- o primeiro foi desenvolvido para ser utilizado juntamente com o instrumento de avaliação gerado e possui especificações de "como" e "por quem" os softwares podem ser avaliados. Este plano contém: um procedimento para a realização da avaliação do produto de software educacional de Matemática direcionado ao Ensino Fundamental, usando o instrumento/questionário gerado (que se encontra na Seção 6.1.1); um guia para a elaboração de um relatório sobre o software avaliado (que se encontra na Seção 6.4); e, um glossário com os termos técnicos utilizados no instrumento gerado (que se encontra como Apêndice A). Dois relatórios, como exemplo, estão disponíveis em [GladcheffoOg]; e,

- o segundo foi o plano elaborado para ser utilizado na Fase 4, contendo especificações de "quando" e "por quem" os softwares seriam avaliados, a fim de obter um feedback inicial sobre o instrumento de avaliação.

\section{$\Rightarrow$ ETAPA: EXECUÇÃo do PLANO de AVALIAÇÃo}

\section{Fase 4: Coleta de Dados}

Os dados (respostas aos questionários) foram coletados através da realização de avaliações de alguns softwares. Estes foram adquiridos após uma pesquisa dos produtos disponíveis no mercado, junto ao comércio varejista, atacadista e fabricantes. Os produtos usados nos experimentos foram os mais utilizados pelas escolas, segundo os comerciantes e fabricantes. São eles:

- Descobrindo a Matemática: direções e grandezas - Positivo Informática (crianças de 3 a 8 anos); 
- Fábrica de Matemática do Monker - Moderna Multimídia (crianças de 3 a 8 anos);

- Extranautas da Matemática - Multieducação Tecnologia Didática (5 $5^{a}$ série);

- Matemática: coleção quero aprender - Ática Multimídia (crianças de 7 a 10 anos);

- Math Blaster - Davidson (crianças de 7 a 10 anos);

- Navegando com as 4 operações - Expoente (crianças de 5 a 10 anos);

- Operação Netuno - The Learning Company (crianças a partir de 11 anos);

- Siracusa - Educare Informática (crianças a partir de 8 anos);

- Supergênios numeramigos - The Learning Company (crianças a partir de 8 anos); e,

- Tabuada - Positivo Informática ( $2^{\mathrm{a}}$ série).

Através do CAEM-USP (Centro de Aperfeiçoamento do Ensino de Matemática), contatamos 22 professores do Ensino Fundamental de Matemática (não envolvidos com os especialistas consultados na fase de coleta de dados da primeira utilização do método GQM) e 14 deles se prontificaram a realizarem as avaliações (10 na própria USP e 4 em casa). Mesmo assim, apenas 8 professores executaram a tarefa. Alguns softwares também foram avaliados pela própria pesquisadora.

Logo em seguida, os professores responderam ao questionário de julgamento do instrumento. 


\section{EXPERIÊNCIA OBTIDA COM ESTA ATIVIDADE:}

$\mathrm{Na}$ data marcada, os softwares foram instalados nas máquinas do IME-USP, mas apenas 4 dos 10 professores que fariam as avaliações na USP compareceram para a tarefa. Estes utilizaram apenas as questões relacionadas à educação, pois não possuíam tempo para que as características técnicas também fossem avaliadas. Esta tarefa durou cerca de 4 horas.

Já os 4 professores que realizaram as avaliações em casa, analisaram também as características técnicas dos softwares.

Cada um deles avaliou um software direcionado ao ciclo do Ensino Fundamental em que leciona. Na seqüência, responderam ao questionário de julgamento do instrumento de avaliação gerado. Este questionário encontra-se em [Gladcheffo0g]. A legibilidade, a completude, a corretude e a consistência foram os pontos checados para a validação dos dados coletados tanto em relação à avaliação dos softwares como à avaliação do instrumento gerado.

O tempo utilizado para as avaliações efetuadas na USP foi considerado por alguns professores como insuficiente. Por este motivo, alegaram que a avaliação do software em si foi realizada de forma superficial. Mesmo assim, foi possível realizar a tarefa de análise do instrumento de avaliação de forma crítica.

De um modo geral, os professores não encontraram dificuldades utilizar o instrumento de avaliação. O vocabulário foi considerado adequado, apesar de terem recorrido ao glossário dos termos técnicos por várias vezes. Isto ressalta a importância deste suporte ao instrumento de avaliação. 
Observando as respostas aos questionamentos, encontramos algumas inconsistências. Com isto, foi necessário anularmos tais dados.

O instrumento foi considerado pela maioria (07 dos 08 professores) um importante apoio para a avaliação de um software educacional. Ressaltamos algumas justificativas:

- sua objetividade;

- sua relativa facilidade de uso;

- auxílio suficiente na abordagem da parte técnica do produto;

- segurança da abrangência dos principais pontos a serem observados no produto;

- possibilidade de uma boa compreensão do que deve ser observado quanto à usabilidade da interface do produto.

Quando questionados sobre a escolha de um software educacional sem o auxílio do instrumento:

- 07 dos 08 professores afirmaram que não teriam lembrado de alguns aspectos técnicos e educacionais;

- a maioria ressaltou que teria se apegado a alguns detalhes, perdendo a objetividade da avaliação; 
- apenas 01 dos 08 professores afirmou que teria observado os mesmos aspectos que se encontram no instrumento (destacamos que se trata do professor que mais apresentou inconsistências em suas respostas).

O principal objetivo desta experiência foi atingido, ou seja, os dados coletados permitiram uma melhoria no instrumento de avaliação.

Na nossa opinião, o instrumento possui uma riqueza em sua abordagem (sem torná-lo complicado) exigindo um relativo empenho do candidato a usuário (avaliador).

Esta experiência demonstrou que mesmo professores não usuários de softwares educacionais, com o apoio deste instrumento, podem analisar de forma consistente um produto disponível no mercado.

\section{Fase 5: Tratamento dos Dados}

Os dados coletados foram analisados e interpretados para fins de refinamento do instrumento de avaliação elaborado.

\section{Etapa: Preparação dos Resultados}

\section{Fase 6: Preparação da Documentação Final}

Um documento final, ou seja, a última versão do instrumento/questionário, com todos os dados coletados durante as avaliações, foi elaborado. Este questionário se encontra na Seção 6.2. 
É preciso ressaltar que tanto a coleta de dados junto a especialistas quanto os produtos de softwares educacionais utilizados foram selecionados nos ambientes educacional e comercial brasileiros, inserindo este trabalho, portanto, num contexto nacional. No entanto, entendemos que muitos dos conceitos ligados à área educacional aqui trabalhados possuem validade universal.

A Figura 5.2.1, apresentada a seguir, representa o esquema resumido das atividades realizadas durante a "Segunda Utilização do Método GQM".

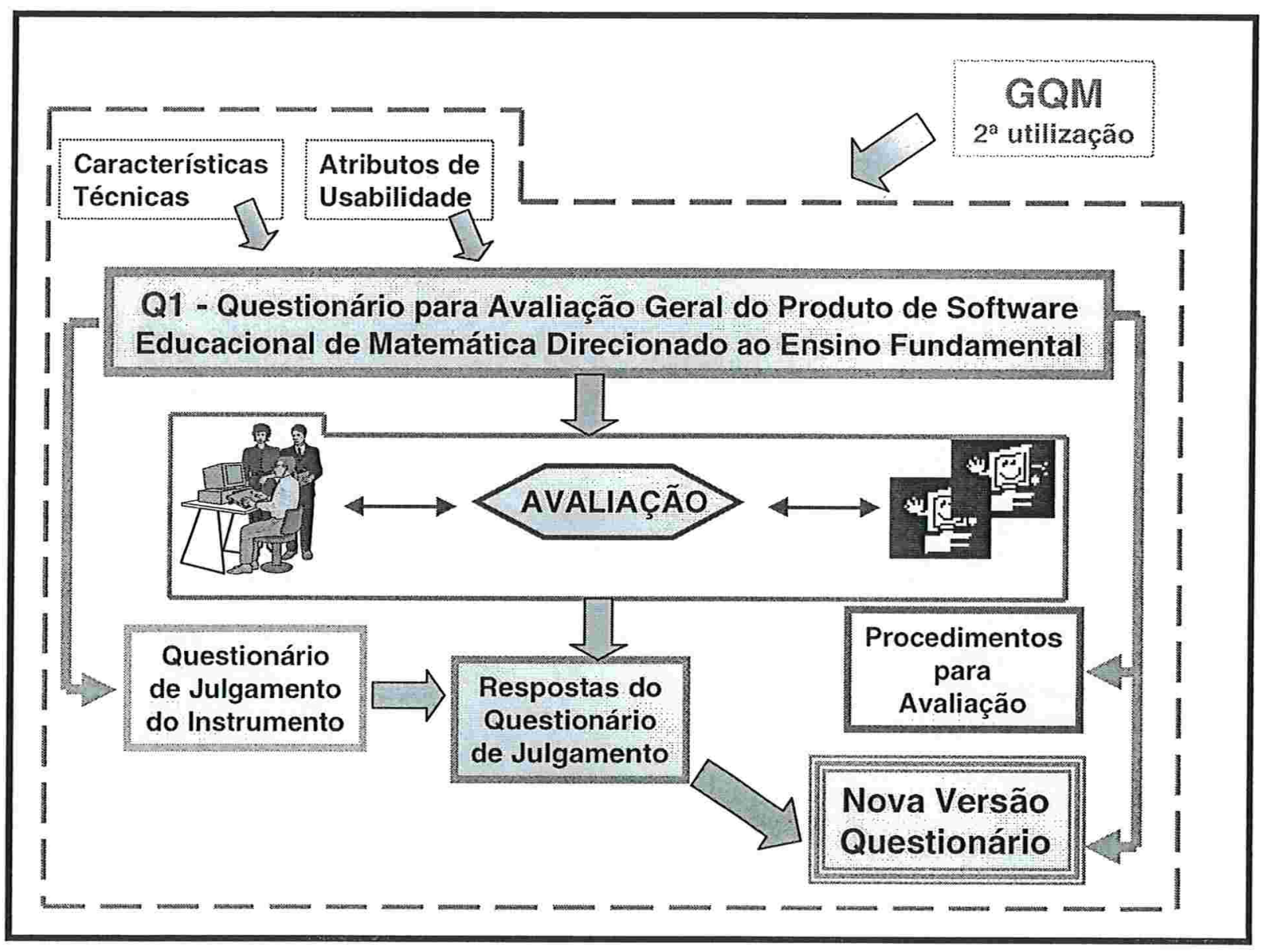

Figura 5.2.1 - Esquema Resumido das Atividades Realizadas Durante a 2 ${ }^{A}$ Utilizaçāo do MÉtodo GQM 


\section{V.III TERCEIRA UtILIZAÇÃo do MÉtodo GQM - ELABORAÇÃo do QUESTIONÁRIO PARA AVALIAÇÃO DA CARACTERÍSTICA "USABILIDADE" DO PRODUTO DE SOFTWARE}

\section{$\Rightarrow$ ETAPA: DesenVolvimento do PLANO GQM}

\section{Fase 1: Pré-Estudo}

Foi identificado o método da "Avaliação Heurística" (descrito na Seção 4.3), para avaliação da característica "usabilidade" proposto por Nielsen [Nielsen93] e, também, conceitos e princípios ligados à interface humano-computador através do curso "Avaliação e Design de Interfaces Humano-Computador", ministrado na Escola de Computação 2000 [Rocha00].

\section{Fase 2: Elaboração do Plano GQM}

O objetivo foi detalhado nos termos seguintes:

Objeto: produto de software educacional de Matemática do Ensino Fundamental.

Propósito: identificar problemas de usabilidade da interface do software que serão indicados por alunos (usuários finais), tomando como base um conjunto de heurísticas (ou princípios) de usabilidade.

Foco de qualidade: a característica usabilidade.

Ponto de vista: o usuário final, aluno.

Ambiente: ensino-aprendizagem de Matemática apoiado por ferramentas computacionais.

Para cada heurística de usabilidade que fez parte da base para a avaliação do produto, foram elaboradas questões a serem feitas aos alunos pelo orientador da 
avaliação, enquanto eles utilizam o software realizando tarefas específicas, elaboradas pelo próprio orientador. O conjunto de heurísticas utilizadas nesta avaliação está descrito na Seção 6.1.2 e o questionário se encontra na Seção 6.3.

\section{Fase 3: Elaboração do Plano de Avaliação}

Um procedimento (descrito na Seção 6.1.2) foi elaborado a fim de auxiliar o professor ou especialista da área educacional na coordenação de uma avaliação da usabilidade da interface do software, realizada por alguns alunos. Este procedimento contém especificações de "quando", "como" e "por quem" a avaliação poderá ser realizada.

A Figura 5.3.1, apresentada a seguir, representa o esquema resumido das atividades realizadas durante a "Terceira Utilização do Método GQM". 


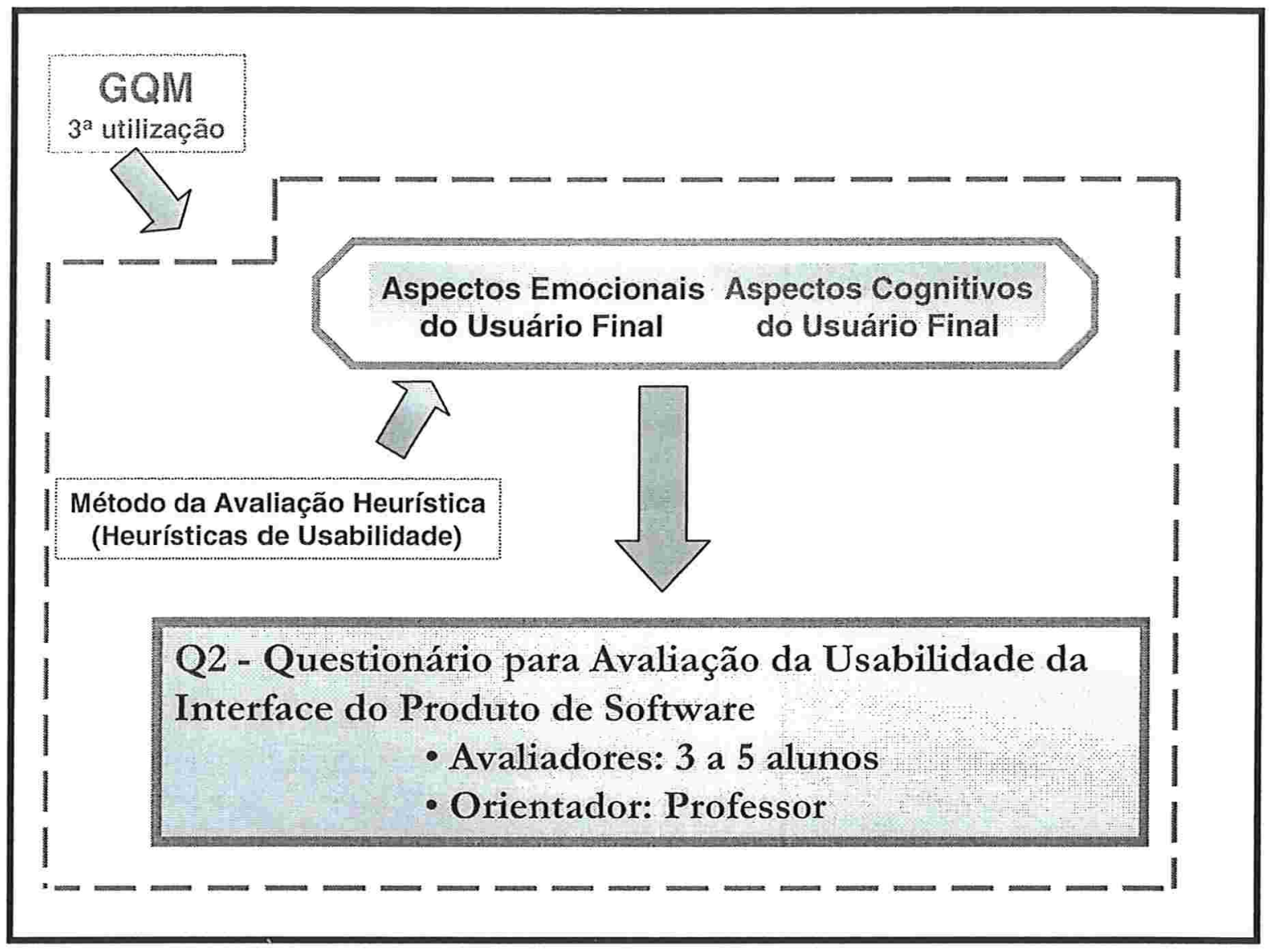

Figura 5.3.1 - ESQUEMA RESUMIdO dAs ATIVIDAdES REALIZADAS DURANTE A $3^{A}$ UTILIZAÇĀo dO MÉTOdO GQM 


\section{Capítulo 6}

\section{Questionários e Procedimentos de Avaliação}

Neste capítulo o instrumento de avaliação para o software educacional de Matemática direcionado ao Ensino Fundamental é apresentado assim como os procedimentos para a realização da avaliação e elaboração de um relatório e, também, um glossário contendo os termos técnicos utilizados nos questionários. Estes documentos têm como objetivo auxiliar as tarefas de avaliação geral do produto realizada pelo professor e, avaliação da usabilidade da interface orientada pelo professor e executada por alguns alunos.

Com isso, temos:

- Uma "Avaliação Geral" do produto, ou seja, uma análise do produto em relação às características de qualidade e verificação da presença de condições mínimas para atendimento das necessidades do usuário final. Esta análise examina o produto como um todo e o procedimento de avaliação utilizado pelo professor é composto por:

- questões que englobam critérios baseados nas Normas ISO/IEC 12119 e ISO/IEC 9126-1;

- questões referentes às características pedagógicas gerais, que abordam critérios ligados à educação, considerados necessários em qualquer tipo de software educacional de Matemática, direcionado ao Ensino Fundamental;

- questões referentes à educação, específicas a cada um dos tipos de software educacional, que podem ser um tutorial, uma simulação, um jogo pedagógico, um sistema hipermídia ou exercício e prática; e, 
- questões que abordam as características pedagógicas relacionadas a cada um dos quatro ciclos do Ensino Fundamental, baseando-se nos objetivos propostos pelos Parâmetros Curriculares Nacionais, ao ensino de Matemática nestes ciclos;

- Uma "Avaliação da Usabilidade do Produto", baseada no método da "Avaliação Heurística". Esta análise é realizada com a participação de alunos (usuários finais), e dirigida pelo professor ou especialista educacional, a fim de serem identificados problemas de usabilidade da interface do software. A base desta avaliação é o conjunto de heurísticas ou princípios de usabilidade enfocando: maior facilidade de aprendizagem, baixa taxa de erros cometidos pelos alunos, satisfação subjetiva e facilidade de retorno. Com esta avaliação, uma lista de problemas da usabilidade do produto é gerada, e estes problemas são classificados em relação à gravidade de cada um, segundo o ponto de vista do professor ou especialista da área educacional.

Essas duas avaliações mostram-se complementares visto que, alguns atributos da característica usabilidade avaliados pelos alunos (usuários finais), podem ser considerados difíceis, ou até mesmo impossíveis de serem verificados apenas pelo professor ou especialistas da área. Como um exemplo podemos citar a "satisfação subjetiva", que pode ser considerado o mais importante deles, ou, pelo menos, o mais difícil de ser avaliado sem a interação com os alunos.

A seguir, na Seção 6.1, apresentamos os procedimentos a serem utilizados para a avaliação do produto de software educacional de Matemática direcionado ao Ensino Fundamental. Estes procedimentos são divididos em duas partes: "Avaliação Geral do Produto de Software Educacional" e "Avaliação da Usabilidade da Interface, direcionada pelo orientador e realizada pelos avaliadores alunos". Na Seção 6.2, os questionários relativos à avaliação geral do produto são apresentados e, as questões relativas à avaliação da usabilidade da interface são apresentadas na Seção 6.3. Caso o avaliador 
deseje elaborar um relatório sobre o produto avaliado, um roteiro sugerindo como fazê-lo é apresentado na Seção 6.4 .

\section{VI.I Procedimentos para Avaliação do Produto de Software Educacional}

\section{VI.I.I Avaliação Geral do Produto de Software Educacional}

AVALIADOR: Professor ou Especialista da área educacional.

OBJETIVO PRINCIPAL DA AVALIACÃ̃O: Analisar o produto de software educacional de Matemática, direcionado ao Ensino Fundamental, baseando-se em conceitos e princípios de qualidade de software ligados tanto a aspectos técnicos como educacionais, para assim verificar a presença de condições mínimas para atendimento das necessidades do usuário final (aluno).

METODOLOGIA UTILIZADA: Respostas às questões relacionadas no questionário de direcionamento para a avaliação da qualidade do produto de software educacional de Matemática direcionado ao Ensino Fundamental. Este questionário encontra-se na Seção 6.2, e é dividido em quatro partes. São elas:

- "Características Técnicas do Software" - questões que abordam as características técnicas de qualidade do software;

? "Características Pedagógicas Gerais" - questões que abordam as características relativas à educação e que são consideradas necessárias em qualquer tipo de software educacional;

? "Características Pedagógicas para um Tipo Específico de Software" - são cinco partes distintas, cada uma relativa a um tipo de software específico. As questões abordam as características relativas à educação, direcionadas ao Ensino Fundamental de Matemática, e são consideradas necessárias para os seguintes tipos de software: tutorial, exercício e prática, simulação, jogo pedagógico e hipermídia ${ }^{13}$;

\footnotetext{
${ }^{13}$ A descrição de cada um dos tipos de software educacional mencionados se encontra na Seção 3.4.
} 


\section{- "Características Pedagógicas para um Ciclo Específico do Ensino}

Fundamental de Matemática" - são quatro partes distintas, cada uma relativa a um ciclo do Ensino Fundamental de Matemática, abordando os objetivos propostos a cada um.

DIRETIVAS GERAIS: As questões que abordam as características "Técnicas" e "Pedagógicas Gerais" serão utilizadas para a avaliação de qualquer categoria de software educacional. Ao manusear o software com o objetivo de responder a estas questões, o professor começará a perceber especificidades do programa e com isso poderá classificálo como sendo um software educacional do tipo: tutorial, exercício e prática, simulação, jogo pedagógico ou hipermídia. Neste momento, a parte das questões que aborda as características "Pedagógicas para um tipo Específico de Software" a ser utilizada na avaliação já pode ser selecionada. E por fim, a parte das questões que aborda as características "Pedagógicas para um Ciclo Específico do Ensino Fundamental de Matemática" deverá ser utilizada, levando em conta o ciclo do Ensino Fundamental onde o software será aplicado.

Ao procurar responder as questões, o professor deve sempre anotar ao lado de cada uma considerações relacionadas a sua resposta. As questões devem ser respondidas da melhor maneira possível, sempre com base em fatos observados e não com base em suposições. Com isso, poderá analisar melhor se o software deve ser utilizado decidindo assim: em que etapa(s) do processo de ensino-aprendizagem, com qual(is) classe(s) ou aluno(s), em que projeto(s), auxiliando qual(is) conteúdo(s), e assim por diante. 


\section{PASSOS PARA A AVALIAÇÃO GERAL:}

1. Caso o software seja do tipo "sistema hipermídia", localizado em um site na Web (Internet), comece sua avaliação pelo passo $\underline{6}$. Caso contrário, leia as questões referentes à "Embalagem" e à "Descrição do Produto", antes de respondê-las. São elas:

Questões: Características Técnicas do Software - Pacote - Embalagem e Descrição do Produto $\searrow$ E.1 a E.2 e D.1 a D.1.27 (situadas na Seção 6.2.1);

2. Observe a embalagem e/ou o documento específico para a descrição do produto, e responda as questões relacionadas no passo $\underline{1}$;

3. Instale o software, seguindo suas instruções para instalação, geralmente contidas na documentação de usuário (ou manual do usuário), e faça uma verificação inicial da documentação de usuário, ou seja, uma verificação inicial de sua estrutura e de seu conteúdo;

4. Leia as questões referentes à "Documentação/Manual do usuário" e ao "Software", antes de respondê-las. São elas:

Questões: Características Técnicas do Software - Pacote Documentação/Manual do Usuário e Software $\Rightarrow$ M.1 a M.16 e S.1 a S.12 (situadas na Seção 6.2.1);

5. Manuseie o software, testando suas funções e, à medida que se forme uma opinião em relação a resposta de cada uma das questões lidas no passo $\underline{4}$, responda-as da melhor maneira possível;

6. Agora serão observadas características ligadas à educação. Para isso, leia as questões que abordam as "Características Pedagógicas Gerais", antes de respondêlas. São elas:

Questões: Características Pedagógicas Gerais $₫$ EDU.1 a EDU.36 (situadas na Seção 6.2.2); 
7. Manuseie o software novamente, procurando formar uma opinião em relação à resposta de cada um das questões lidas no passo $\underline{6}$ e responda-as da melhor maneira possivel;

8. Neste momento, serão observadas características ligadas à educação, específicas ao tipo de software que está sendo avaliado. O software já foi manuseado, portanto já é possível decidir qual é o seu tipo. Assim, classifique-o:

\begin{tabular}{||c|l|cc||}
\hline $\begin{array}{c}\text { TIPO } \\
\text { SELECIONADO }\end{array}$ & \multicolumn{1}{|c|}{ TIPO } & \multicolumn{2}{c||}{ QUESTÕES } \\
\hline & Exercício e Prática & EXER.1 A EXER.35 (SITUADAS NA SEÇĀO 6.2.3.1) \\
\hline & Tutorial & TUT.1 A TUT.35 (SITUADAS NA SEÇÃO 6.2.3.2) \\
\hline & Jogo Pedagógico & JOGO.1 A JOGO.35 (SITUADAS NA SEÇÃO 6.2.3.3) \\
\hline & Simulação & SIMU.1 A SIMU.17 (SITUADAS NA SEÇĀO 6.2.3.4) \\
\hline & Sistema Hipermídia & HIPER.1 A HIPER.33 (SITUADAS NA SEÇĀO 6.2.3.5) \\
\hline
\end{tabular}

9. Selecione a parte que aborda as "Características Pedagógicas para um Tipo Específico de Software" de acordo com a sua classificação e leia-a, antes de responder as questões nela contida;

10. Logo após, manuseie o software novamente procurando formar uma opinião em relação à resposta de cada uma das questões lidas no passo $\underline{9}$ e responda-as da melhor maneira possível;

11. Por fim, as características ligadas à educação referentes aos objetivos propostos para o ensino de Matemática de acordo com o ciclo ao qual o software se destina serão observadas. Para isto, leia a parte das questões que aborda as "Características Pedagógicas para um Ciclo Específico do Ensino Fundamental de Matemática" de acordo com o ciclo em que o software será aplicado, procurando formar uma opinião em relação a cada uma, para com isso, posteriormente, respondê-las da melhor maneira possível. 


\begin{tabular}{||l|l|l||}
\hline \hline PARTE SELECIONADA & CICLO & QUESTÕES \\
\hline & Primeiro ciclo & PC.1 A PC.4 (SITUADAS NA SEÇĀo 6.2.4.1) \\
\hline & Segundo ciclo & SC.1 A SC.10 (SITUADAS NA SEÇĀO 6.2.4.2) \\
\hline & Terceiro ciclo & TC.1 A TC.16 (SITUADAS NA SEÇĀO 6.2.4.3) \\
\hline & Quarto ciclo & QC.1 A QC.10 (SITUADAS NA SEÇĀO 6.2.4.4) \\
\hline
\end{tabular}

12. Com todas as etapas anteriores executadas, a avaliação geral da qualidade do produto de software educacional está completa. Assim, um relatório sobre o software pode ser elaborado. Para isto, as instruções contidas na Seção 6.4 (Elaborando um relatório sobre o software avaliado) podem ser seguidas.

\section{VI.I.II Avaliação da Usabilidade da Interface, dirigida pelo orientador e realizada pelos alunos avaliadores}

AVALIADORES: De três (3) a cinco (5) alunos.

ORIENTADOR: Professor ou Especialista da área educacional.

OBJETIVO PRINCIPAL DA AVALIACÃ̃O ORIENTADA PELO PROFESSOR: Identificar problemas de usabilidade da interface do software, que serão indicados por alunos (usuários finais), tomando como base um conjunto de heurísticas (ou princípios) de usabilidade.

MetOdologia UTILIZADA: Método da "Avaliação Heurística" proposto por Nielsen [Nielsen94]. A descrição do método se encontra na Seção 4.3 e estas são as heurísticas que formarão a base para esta avaliação:

- Ajuda aos usuários no reconhecimento, diagnóstico e correção de erros;

(2) Controle do usuário e liberdade;

(D) Documentação e ajuda aos usuários (limitando-se à avaliação do sistema de ajuda on line);

DReconhecimento ao invés da recorrência à memória do usuário; 
- Relação entre o sistema e o mundo real;

$\rightarrow$ Satisfação subjetiva, e;

D Simplicidade e estética do sistema.

DIRETIVAS GERAIS: Para cada heurística, são apresentadas questões a serem propostas aos alunos pelo orientador da avaliação, enquanto eles utilizam o software realizando tarefas específicas, elaboradas pelo próprio orientador. Este questionário se encontra na Seção 6.3.

PASSOS A SEREM EXECUTADOS PELO PROFESSOR (OU ESPECIALISTA DA ÁREA EDUCACIONAL), PARA A AVALIACCẢO DA USABILIDADE DA INTERFACE DO PRODUTO DE SOFTWARE:

1. Após a avaliação geral do software, escolha aleatoriamente de três (3) a cinco (5) crianças pertencentes à sala de aula, onde o produto poderá ser utilizado;

2. Elabore algumas tarefas a serem executadas pelos alunos selecionados a fim de que utilizem as funções do software, para com isto encontrar problemas na usabilidade da interface do produto;

3. Enquanto os alunos utilizam o software realizando as tarefas elaboradas, questione cada um individualmente, com base nas heurísticas de usabilidade e nas questões relativas a cada uma delas. As questões referentes a esta avaliação encontram-se na Seção 6.3;

4. Baseando-se nas respostas de cada aluno, gere uma lista de problemas de usabilidade para cada um, assim como uma lista de aspectos considerados positivos;

5. Consolide as listas de problemas de usabilidade geradas em uma única lista. Esta lista irá relacionar os problemas de usabilidade do produto avaliado, detectados pelos alunos;

6. Da mesma forma, consolide as listas dos aspectos positivos de usabilidade geradas, em uma única lista. Esta lista irá relacionar os aspectos positivos na usabilidade do produto avaliado, detectados pelos alunos; 
7. Por fim, avalie, de acordo com o seu ponto de vista, a gravidade de cada problema detectado, assim como a importância de cada aspecto positivo. Esta avaliação auxiliará sua decisão sobre a utilização ou não do produto em suas aulas. Estas informações também são importantes, e podem ser relacionadas no relatório, caso este venha a ser desenvolvido. As instruções para a elaboração do relatório estão contidas na Seção 6.4 .

\section{VI.II Questionário para a Avaliação Geral do Produto de Software

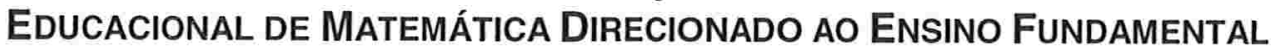

\section{VI.II.I Características Técnicas do Produto de Software}

O produto de software é composto por um pacote e programas. O pacote inclui a "embalagem", um documento de "descrição do produto" e a "documentação de usuário". Os programas incluem seqüências completas das instruções a serem executadas pelo computador, ou seja, "o próprio software em si".

A descrição do produto é um documento expondo as propriedades do produto de software, com o principal objetivo de auxiliar os potenciais compradores na avaliação da adequação do produto antes de sua aquisição. Este documento é uma parte do conjunto de documentação do produto. A descrição das propriedades do produto pode estar disponível na embalagem, em um disquete de apresentação do produto, em uma home page ou em outro meio qualquer, mas é preciso que esteja disponível ao usuário antes da aquisição ou não do produto.

A documentação de usuário é o conjunto completo de documentos, disponível na forma impressa ou não, que é fornecido para a utilização de um produto, sendo também parte integrante do produto. Pode ser chamado também de manual do usuário. 
Caso o produto não possua um documento específico para "Descrição do Produto", a descrição das propriedades do produto deverá estar contida na sua própria embalagem. Sendo assim, as questões referentes a "Descrição do Produto" devem ser respondidas também quando se está avaliando a embalagem do produto.

A seguir apresentamos um conjunto de questões proposto para avaliação das características técnicas do produto de software, baseado nas Normas ISO/IEC 9126-1 e ISO/IEC 12119, e em opiniões fornecidas por especialistas da área educacional [Gladcheff99] [Gladcheff00a] [Gladcheff00b] [Gladcheff00c] [Gladcheff00d] [Gladcheff00e] [Gladcheffo0f] . Estas questões estão divididas em:

1. Pacote

1.1. Embalagem

1.2. Descrição do Produto

1.3. Documentação de Usuário/Manual do Usuário (Impresso ou on line)

2. Software

Observação: A sigla NN significa "Não é Necessário para este produto".

\section{Questões - PACOTE}

\section{EMBALAGEM}

E.1 A embalagem possui:

E.1.1 um aspecto visual satisfatório?
( ) SIM
( ) NÃO

E.1.2 material resistente para proteger os itens nela encontrados?
( ) SIM
( ) NÃO

E.1.3 facilidade de manuseio aos itens que estão dentro dela?

( ) SIM ( ) NÃO 
E.2 As informações podem ser encontradas facilmente?
( ) SIM
( ) $\mathrm{NÃO}$

\section{DESCRICAO DO PRODUTO}

D.1. O documento de descrição do produto possui:

D.1.1 sua própria identificação, ou seja, a identificação de que se trata de um documento de "descrição do produto" que pode também ser chamado, por exemplo, de "descrição funcional" ou "informação do produto"?
( ) SIM
( ) NÃO

D.1.2 o nome do produto?
( ) SIM
( ) NÃO

D.1.3 a versão ou data do produto?
( ) SIM
( ) NÃO

D.1.4 o nome do produtor?
( ) SIM
( ) NÃO

D.1.5 o nome de pelo menos um fornecedor?
( ) SIM
( ) NÃO

D.1.5.1 se SIM, possui um meio de contato para o consumidor?
( ) SIM
( ) NÃO

D.1.6 indicação dos requisitos de hardware necessários para colocar o produto em uso?

- tamanho da memória principal (RAM)
( ) SIM
( ) NÃO

- tamanho da memória auxiliar (HD)

( ) SIM ( ) NÃO

- placas de expansão

$\begin{array}{llll}\text { FAX/Modem e velocidade } & \text { ( ) SIM } & \text { ( ) NÃO } & \text { ( ) NN } \\ \text { som } & \text { ( ) SIM } & \text { ( ) NÃO } & \text { ( ) NN } \\ \text { rede e velocidade } & \text { ( ) SIM } & \text { ( ) NÃO } & \text { ( ) NN } \\ \text { vídeo } & \text { ( ) SIM } & \text { ( ) NÃO } & \\ \text { scanner } & \text { ( ) SIM } & \text { ( ) NÃO } & \text { ( ) NN }\end{array}$

- unidades de entrada/saída

$\begin{array}{llll}\text { configuração da impressora ( ) SIM } & \text { ( ) NÃO } & \text { ( ) NN } \\ \text { CD ROM e velocidade } & \text { ( ) SIM } & \text { ( ) NÃO } & \text { ( ) NN } \\ \text { disquete } & \text { ( ) SIM } & \text { ( ) NÃO } & \text { ( ) NN } \\ \text {, Mac, PDA - Personal Digital Assistant) } & \text { ( ) SIM } & \text { ( ) NÃO } \\ & \text { ( ) SIM } & \text { ( ) NÃO } & \end{array}$


D.1.6.1 os requisitos de hardware necessários para a utilização do produto são compatíveis com os requisitos do computador onde será utilizado?
( ) SIM
( ) NEM TODOS
( ) NÃO

D.1.7 indicação dos requisitos de software necessários para colocar o produto em uso?

- sistema operacional (Win95, Win98, Win2000, Linux, MAC OS, Palm OS,...)

- outros softwares (planilhas, editores, browsers, vídeo, ...)

$$
\text { ( ) SIM ( ) NÃO }
$$

$$
\text { ( ) } \operatorname{SIM~(~)~NÃO~(~)~NN~}
$$

D.1.7.1. os requisitos de software necessários para colocar o produto em uso são compatíveis com os softwares instalados no computador a ser utilizado?
( ) SIM
( ) NEM TODOS
( ) NÃO

D.1.8 uma declaração mencionando se a instalação do produto pode ser conduzida pelo próprio usuário?
( ) SIM
( ) NÃO

D.1.9 indicação da faixa etária a que se destina o produto?
( ) SIM
( ) NÃO

D.1.10 indicação do conteúdo programático abordado no software?
( ) SIM
( ) $\mathrm{NÃO}$

D.1.11 indicação do tipo de software educacional que se trata (tutorial, exercício e. prática, simulação, sistema hipermídia, jogo, sistema de autoria, etc)?
( ) SIM
( ) NÃO

D.1.12 indicação dos componentes entregues com o produto (disquetes, CD ROM, manual impresso, ...)?
( ) SIM
( ) NÃO

D.1.13 uma declaração sobre possíveis interfaces com outros produtos?
( ) SIM
( ) NÃO
( ) $\mathrm{NN}$

D.1.13.1 se possui interface com outros produtos, identifica tais produtos?
( ) SIM
( ) NÃO

D.1.14 indicação de fornecimento de suporte técnico?
( ) SIM
( ) NÃO

D.1.14.1 se SIM, possui a indicação se é limitado por tempo?
( ) SIM
( ) NÃO

D.1.15 indicação de fornecimento de manutenção? (Ex: se uma nova versão é criada, o usuário tem direito à atualização do produto grátis.)
( ) SIM
( ) NÃO 
D.1.16 indicação de que, se a escola e/ou professor considerar conveniente que os alunos possuam uma cópia do software para ser utilizado em casa, o produtor (ou o fornecedor) oferece vantagens para a aquisição do produto por parte dos pais dos alunos?
( ) SIM
( ) NÃO
( ) NN

D.1.17 uma visão geral das funções/atividades disponíveis no produto?
( ) SIM
( ) NÃO

D.1.18 indicação a respeito de possíveis valores limite para utilização do produto? (Ex: número máximo ou mínimo de participantes para um jogo.)
( ) SIM
( ) NÃO
( ) NN

D.1.19 indicação sobre sua confiabilidade? (Ex: se é possível fazer uma cópia de segurança.)
( ) SIM
( ) NÃO
( ) NN

D.1.20 indicação do tipo de interface com o usuário utilizada? (linha de comando, janelas, menu, ...)
( ) SIM
( ) NÃO

D.1.21 descrição de um possível conhecimento específico necessário para a aplicação do produto?
( ) SIM
( ) NÃO
( ) NN

D.1.22 declaração de todos os idiomas utilizados na documentação de usuário e na interface com o usuário (incluindo mensagens de erro e outras mensagens)?
( ) SIM
( ) NÃO

D.1.23 declaração sobre possíveis adaptações do produto por parte do professor? (Ex: mudança de moeda utilizada no produto, ...)
( ) SIM
( ) NÃO
( ) NN

D.1.24 declaração sobre possível inserção de novos exemplos e/ou exercícios por parte do professor?
( ) SIM
( ) NÃO
( ) NN

D.1.25 declaração se o produto possui proteção contra infrações a direitos autorais? (Ex: data programada para expiração do produto, proteção técnica contra cópias do produto, ...)
( ) SIM
( ) NÃO

D.1.26 declarações sobre o desempenho do produto?
( ) SIM
( ) NÃO

D.1.27 declarações/ informações sobre como o produto foi desenvolvido?
( ) SIM
( ) NÃO 


\section{DOCUMENTAÇÃO DE USUARIO/ MANUAL DO USUÁRIO (impresSO ou on line)}

O manual do usuário deve ser avaliado em conjunto com a avaliação do software.

Todas as informações colocadas na "Descrição do Produto" (ou embalagem) devem estar presentes na documentação do usuário, e de forma mais detalhada, para que a documentação possa ser considerada completa. Verifique então se estas informações se encontram na documentação.

M.1 As informações descritas na "Descrição do Produto" (ou embalagem) são encontradas também na documentação, de forma mais detalhada?
( ) SIM
( ) QUASE INTEIRAMENTE
( ) POUCO
( ) NÃO

M.2 A documentação possui:

M.2.1 instruções para instalação do produto?
( ) SIM
( ) NÃO

M.2.1.1 se SIM, as instruções estão corretas?
( ) SIM
( ) NÃO

M.2.1.2 se SIM, as instruções são de fácil compreensão?
( ) SIM
( ) NÃO

M.2.1.3 se SIM, as instruções estão completas?
( ) SIM
( ) NÃO

M.2.2 instruções para desinstalação do produto?
( ) SIM
( ) NÃO

M.2.2.1 se SIM, as instruções estão corretas?
( ) SIM
( ) NÃO

M.2.2.2 se SIM, as instruções são de fácil compreensão?
( ) SIM
( ) NÃO

M.2.3 uma indicação dos objetivos do software ao ser utilizado na educação?
( ) SIM
( ) NÃO

M.2.3.1 Se SIM, os objetivos estão de acordo com as expectativas?
( ) SIM
( ) QUASE INTEIRAMENTE
( ) POUCO
( ) NÃO

M.2.4 índice geral do conteúdo?
( ) SIM
( ) NÃO

M.2.4.1 Se SIM, o índice é bem organizado?
( ) SIM
( ) QUASE INTEIRAMENTE
( ) POUCO
( ) NÃO 
M.2.5 índice remissivo?
( ) SIM
( ) NÃO

M.2.5.1 Se SIM, o índice é completo?
( ) SIM
( ) QUASE INTEIRAMENTE
( ) POUCO
( ) NÃO

M.2.6 glossário de termos técnicos que utiliza?
( ) SIM
( ) NÃO
( ) NN

M.2.7 instruções para manutenção, caso tenha sido declarado pelo produtor que a manutenção pode ser realizada pelo usuário?
( ) SIM
( ) NÃO
( ) $\mathrm{NN}$

M.3 A documentação possui uma apresentação visual adequada?
( ) SIM
(
QUA
INTEIRAMENTE
( ) POUCO
( ) NÃO

M.4 É oferecido um meio de contato com o produtor e/ou fornecedor, que trate de sugestões, críticas, correções, etc, por parte do professor?
( ) SIM
( ) NÃO

M.5 Todas as funções e/ou atividades que o software executa estão descritas na documentação?
( ) SIM
( ) QUASE INTEIRAMENTE
( ) POUCO
( ) NÃO

M.5.1 A descrição de como executar/utilizar as funções apresenta-se de forma compreensível?
( ) SIM
( ) QUASE INTEIRAMENTE
( ) POUCO
( ) $\mathrm{NÃO}$

M.6 Quando necessário, a documentação faz uso de exemplificações?
( ) SIM
( ) QUASE INTEIRAMENTE
( ) POUCO
( ) NÃO

M.7 Quando possível, a documentação faz uso de ilustrações?
( ) SIM
( ) QUASE INTEIRAMENTE
( ) POUCO
( ) NÃO

M.8 A documentação possui:

M.8.1 erros gramaticais?
( ) SIM
( ) NÃO

M.8.2 ambigüidades?
( ) SIM
( ) $\mathrm{NÃO}$

M.9 Existem erros nas definições e/ou exemplificações apresentadas pelo manual?
( ) SIM
( ) NÃO

M.10 Existem contradições internas na documentação? (Ex: as páginas relacionadas nos índices não correspondem às informações indicadas, ...)
( ) SIM
( ) QUASE INTEIRAMENTE
( ) POUCO
( ) NÃO

M.11 Existem contradições entre o que a documentação apresenta e o que o software executa?
( ) SIM
( ) QUASE INTEIRAMENTE
( ) POUCO
( ) NÃO 
M.12 Os termos utilizados no manual/documentação estão no mesmo idioma que os da interface?
( ) SIM
( ) NÃO

M.13 Os termos utilizados no manual/documentação são os mesmos utilizados pelo software?
( ) SIM
( ) QUASE INTEIRAMENTE
( ) POUCO
( ) NÃO

M.14 As mensagens que o software retorna, quando necessário, são explicadas na documentação?
( ) SIM
( ) NEM TODAS
( ) NÃO
( ) NN

M.15 A documentação é concisa e completa? (Concisa no sentido de que não existem informações repetitivas que poderiam não estar no manual e completa no sentido de que o manual contém todas as informações necessárias que ajudam na utilização do produto)
( ) SIM
( ) QUASE INTEIRAMENTE
( ) POUCO
( ) NÃO

M.16 Se o software possui a possibilidade de inserção de novos exemplos por parte do professor, a documentação possui as instruções necessárias para tal atividade?
( ) SIM
( ) NÃO
( ) $\mathrm{NN}$

\section{Questões - SOFTWARE}

S.1 O software foi desenvolvido por uma entidade (empresa/produtora/universidade/...) de confiança?
( ) SIM
( ) NÃO

S.2 O software é fácil de ser instalado?
( ) SIM
( ) NÃO

S.3 Foi possível instalar o software corretamente?

( ) SIM ( ) OCORRERAM ALGUNS PROBLEMAS

( ) OCORRERAM MUITOS PROBLEMAS ( ) NÃO

S.4 O software é fácil de ser desinstalado?
( ) SIM
( ) NÃO

S.5 As funções disponíveis são suficientes para realizar as tarefas pelas quais o software se propõe?
( ) SIM
( ) QUASE INTEIRAMENTE
( ) POUCO
( ) NÃO 
S.6 Quando as funções são ativadas, executam o que é esperado delas? (Ex: "rotacionar uma figura para a direita", a função executa exatamente esta rotação)
( ) SIM
( ) QUASE INTEIRAMENTE
( ) POUCO
( ) $\mathrm{NÃO}$

S.7 O software permite a leitura de arquivos com dados em diferentes formatos, gerados até por outros softwares?
( ) SIM
( ) NÃO
( ) NN

S.8 O software permite a gravação de arquivos com dados em diferentes formatos, que possam ser lidos por outros softwares?
( ) SIM
( ) NÃO
( ) NN

S.9 O software está de acordo com as convenções e definições relacionadas à Matemática?
( ) SIM
( ) QUASE INTEIRAMENTE
( ) POUCO
( ) NÃO

S.10 O software possui recursos para acesso seletivo? (Ex: senha para cada usuário ou para cada grupo de usuários.)
( ) SIM
( ) NÃO
( ) $\mathrm{NN}$

S.11 O software apresentou falhas durante sua utilização? (Ex: travamento da máquina, volta ao sistema operacional quando, por exemplo, se colocam valores fora da faixa especificada ...)
( ) MUITAS
( ) POUCAS
( ) NÃO adequada?

S.11.1 Se MUITAS ou POUCAS, a recuperação dos dados afetados é
( ) SIM
( ) QUASE INTEIRAMENTE
( ) POUCO
( ) NÃO

S.12 O software possui algum tipo de proteção contra o uso de cópias indevidas?
( ) SIM
( ) NÃO

\section{VI.II.II Características Pedagógicas Gerais}

A seguir apresentamos um conjunto de questões importantes na avaliação das características pedagógicas gerais de um produto de software educacional, baseado em [Cristovão97b], [Gladcheff99], [Gladcheff00a], [Gladcheff00b], [Gladcheff00c], [Gladcheff00d], [Gladcheff00e], [Gladcheff00f], [ISO9126-1] e [Loureiro98].

Observação: A sigla NN significa "Não é Necessário para este produto". 


\section{Questões - CARActerísticas Pedagógicas Gerais}

\section{Objetivos}

EDU.1 -

Quais são os objetivos em relação à Matemática que você pretende alcançar, utilizando o software como ferramenta de auxílio?

EDU.2-

O software possui "pelo menos" um dos itens: Projeto ou Manual Pedagógico / Plano de Ensino / Proposta Educacional?

( ) SIM ( ) NÃO

EDU.2.1 - Se SIM, qual(is)?

( ) Projeto ou Manual Pedagógico

( ) Plano de Ensino

( ) Proposta Educacional

EDU.2.2 - Se SIM, o conteúdo contido neste(s) documento(s) é coerente com os seus princípios de educador(a)?
( ) SIM
( ) QUASE INTEIRAMENTE
( ) POUCO
( ) NÃO

EDU.3 -

O software se encaixa com a proposta curricular da escola?
( ) SIM
( ) NÃO 
EDU.4 -

O software oferece situações e recursos que justifiquem sua utilização?
( ) SIM
( ) QUASE INTEIRAMENTE
( ) POUCO
( ) NÃO

\section{Usabilidade - Interface}

\section{EDU.5 -}

O tipo de interface utilizada pelo software é adequada à faixa etária a que se destina?
( ) SIM
( ) NÃO

EDU.6 -

As representações das funções da interface (ícones, menus, etc) são fáceis de serem reconhecidas/entendidas?
( ) SIM
( ) QUASE INTEIRAMENTE
( ) POUCO
( ) $\mathrm{NÃO}$

EDU.7-

As funções são fáceis de serem utilizadas?

EDU.8 -
( ) SIM
( ) QUASE INTEIRAMENTE
( ) POUCO
( ) NÃO

As informações contidas na interface são de fácil leitura?
( ) SIM
( ) $Q$
QUASE INTEIRAMENTE
( ) POUCO
( ) NÃO

EDU.9-

A quantidade de informação colocada em cada tela é apropriada à faixa etária a que se destina o software?
( ) SIM
( ) QUASE INTEIRAMENTE
( ) POUCO
( ) NÃO

EDU.10 -

O software oferece uma linguagem sintaticamente homogênea, ou seja, de forma padronizada?
( ) SIM
( ) NÃO

EDU.11 -

A interface possui erros de linguagem?
( ) SIM
( ) QUASE INTEIRAMENTE
( ) POUCO
( ) NÃO

EDU.12-

O software possui comportamento semelhante em situações semelhantes, ou seja, solicita do usuário ações similares para tarefas similares?
( ) SIM
( )NÃO 


\section{EDU.13-}

As mensagens e menus exibidos na interface estão no mesmo idioma que o manual do usuário?
( ) SIM
( ) NÃO

EDU.14-

As mensagens exibidas são "amigáveis", ou seja, explicativas e positivas?
( ) SIM
( ) QUASE INTEIRAMENTE
( ) POUCO
( ) NÃO

\section{EDU.15 -}

As mensagens exibidas são claras e fáceis de serem entendidas, estando de acordo com a faixa etária a que se destina o software?
( ) SIM
( ) QUASE INTEIRAMENTE
( ) POUCO
( ) NÃO

EDU.16-

A interface informa ao usuário o andamento das tarefas que estão sendo realizadas?
( ) SIM
( ) NÃO
( ) NN

EDU.17-

O tempo de resposta para as operações interativas é adequado à faixa etária a que se destina o software?
( ) SIM
( ) NÃO
( ) NN

EDU.18 -

Existem saídas claras de emergência, onde o aluno possa deixar um estado não desejado, quando escolheu erroneamente uma função do software, sem que o fluxo do diálogo e sua continuidade sejam prejudicados? (O software possui o "desfazer" e o "refazer"?)

$$
\text { ( ) SIM ( ) NÃO }
$$

EDU.19-

O software possui uma forma de prevenir erros que possam ser cometidos pelo aluno? (Problema exemplo: A máquina pode travar caso o CD-ROM não seja colocado em seu drive antes do software ser ativado ou quando o CD-ROM é tirado do drive antes do software ser desativado.)
( ) SIM
( ) NÃO

EDU.20 -

A animação, o som e outras mídias são agradáveis?

EDU.21 -
( ) SIM
( ) QUASE INTEIRAMENTE
( ) POUCO
( ) NÃO

O software oferece a opção de tirar o som, caso necessário?
( ) SIM
( ) $\mathrm{NÃO}$
( ) $\mathrm{NN}$ 


\section{EDU.22 -}

As cores são utilizadas com equilíbrio, ou seja, são bem distribuídas evitando assim poluição visual?
( ) SIM
( ) QUASE INTEIRAMENTE
( ) POUCO
( ) NÃO

EDU.23 -

A interface possui "sistema de ajuda" ou "help on-line"?
( ) SIM
( ) NÃO

EDU.23.1 Se SIM, possui alta conectividade, ou seja, permite que o aluno recorra ao sistema de ajuda em qualquer tela que se encontre?

$$
\text { ( ) } \operatorname{SIM} \text { ( ) NÃO }
$$

EDU.23.1.1 Se EDU.23.1 for SIM, a ajuda é sensitiva ao contexto, ou seja, é apresentada relativa ao ponto onde o aluno se encontrava no momento em que a solicitou?
( ) SIM
( ) NÃO

EDU.23.2 Se EDU.23 for SIM, é adequada, ou seja, explica as dúvidas do usuário adequadamente?

$$
\text { ( ) SIM ( ) NÃO }
$$

EDU.24 -

A entrada dos dados é realizada de forma padronizada?
( ) SIM
( ) NÃO
( ) NN

EDU.25 -

Os dados inseridos são validados pelo software, quando necessário?
( ) SIM
( ) NÃO
( ) NN

\section{Conceitos}

EDU.26 -

O software explicitou os conceitos com que se propõe a trabalhar?
( ) SIM
( ) NÃO 
EDU.27 -

Liste os conceitos que o software trabalhou:

EDU.27.1 - Todos os conceitos que você deseja trabalhar com seus alunos estão na lista acima, da questão EDU.27?
( ) SIM
( ) QUASE TODOS
( ) FALTARAM MUITOS
( ) NÃO

EDU.27.2 - Existem conceitos enfocados pelo software que você não deseja trabalhar com seus alunos ao utilizá-lo?

( ) SIM ( ) NÃO

EDU.27.2.1 - Se SIM, o software permite que o conteúdo a ser abordado seja limitado de forma a incluir apenas o que se deseja trabalhar?

( ) $\operatorname{SIM}$ ( ) NÃO

EDU.27.2.1.1 - Se EDU.27.2.1 for NÃO, você se sente à vontade para utilizar o software mesmo assim?
( ) SIM
( ) NÃO

EDU.28 -

Os conceitos trabalhados pelo software podem ser relacionados com outros conceitos da Matemática?
( ) SIM
( ) ALGUNS
( ) NÃO

EDU.28.1 - Se SIM ou ALGUNS, liste os conceitos matemáticos com que o software pode propiciar uma interconexão: 
EDU.28.2 - O software explora a interconexão entre os conceitos trabalhados e os conceitos listados na questão EDU.28.1?
( ) SIM
( ) QUASE INTEIRAMENTE
( ) POUCO
( ) NÃO

EDU.29 -

Os conceitos trabalhados pelo software podem ser relacionados com conceitos de outras disciplinas?
( ) SIM
( ) ALGUNS
( ) NÃO

EDU.29.1 - Se SIM ou ALGUNS, liste os conceitos e a disciplina a que cada um pertence com o qual o software pode propiciar uma interconexão:

EDU.29.2 - O software explora a interconexão entre os conceitos trabalhados e os conceitos e respectivas disciplinas listados acima, na questão EDU.29.1?
( ) SIM
( ) QUASE INTEIRAMENTE
( ) POUCO
( ) NÃO

EDU.30 -

O conteúdo trabalhado pelo software pode propiciar a sua interação com temas transversais?
( ) SIM
( ) ALGUNS
( ) NÃO

EDU.30.1 - Se SIM ou ALGUNS, liste o conteúdo específico juntamente com o(s) tema(s) transversal(is) com que o software pode propiciar uma interação:

\section{EDU.31 -}

A forma de abordagem dos conceitos permite que o aluno os compreenda de forma adequada?
( ) SIM
( ) QUASE INTEIRAMENTE
( ) POUCO
( ) NÃO 


\section{Praticidade}

EDU.32 -

O software possui a possibilidade de inserção de novos exemplos e/ou exercícios por parte do professor?
( ) SIM
( ) NÃO
( ) NN

EDU.33 -

O software possui uma versão para ser utilizado em rede?
( ) SIM
( ) NÃO
( ) NN

EDU.34 -

O software recolhe sugestões e/ou reclamações por parte do professor?
( ) SIM
( ) NÃO

EDU.35 -

O software recolhe sugestões e/ou reclamações por parte do aluno?
( ) SIM
( ) NÃO

EDU.36 -

O preço do software é compatível com o orçamento da escola?
( ) SIM
( ) NÃO
( ) NN 


\section{VI.II.III Características Pedagógicas para um Tipo Específico de Software}

\section{Educacional}

Como já colocado, os tipos de software contemplados nesta avaliação são:

1. Exercício e Prática;

2. Tutorial;

3. Jogo Pedagógico;

4. Simulação e;

5. Sistema Hipermídia.

Para cada um, apresentamos um conjunto de questões importantes na avaliação das características pedagógicas relativas ao tipo de software educacional no qual o produto avaliado se enquadra. Estes questionários são baseados em [Braga96], [Campos94a], [Campos94b], [Campos99b], [Cristovão97b], [Gladcheff99], [Gladcheff00a], [Gladcheff00b], [Gladcheff00c], [Gladcheff00d], [Gladcheff00e], [Gladcheff00f], [Leite96], [Nielsen99], [Rocha00] e [Valente93]. 


\section{VI.II.III.I QUestões - Características Pedagógicas "ExercícIo e PrÁticA"}

(A sigla NN significa "Não é Necessário para este produto")

\section{Vocabulário}

EXER.1 -

A linguagem utilizada está no nível de compreensão do aluno? (vocabulário, metáforas, etc)
( ) SIM
( ) NÃO

EXER.2 -

O vocabulário é adequado, sem deixar de ser científico quando necessário?
( ) SIM
( ) QUASE INTEIRAMENTE
( ) POUCO
( ) NÃO

EXER.3 -

O software utiliza termos iguais com significados diferentes?
( ) NÃO
( ) SIM

\section{EXER.4 -}

O software utiliza termos diferentes com o mesmo significado?
( ) NÃO
( ) SIM

\section{Conceitos Matemáticos}

\section{EXER.5 -}

Os conceitos matemáticos definidos pelo software estão corretos?
( ) SIM
( ) QUASE INTEIRAMENTE
( ) POUCO
( ) NÃO

\section{EXER.6 -}

As notações são adequadas e coerentes com as utilizadas pelo professor em sala de aula?
( ) SIM
( ) NÃO

\section{Conteúdd}

\section{EXER.7 -}

O software permite que o conteúdo seja particularizado para cada aluno, ou seja, permite que o conteúdo a ser abordado seja limitado de acordo com o que se deseja trabalhar com cada aluno, individualmente?
( ) SIM
( ) NÃO
( ) NN 


\section{EXER.8 -}

O software enfoca todos os passos necessários ao treinamento do assunto a ser trabalhado de acordo com o estágio em que se encontra o aluno? (Ex: multiplicação $\Rightarrow$ por 1 algarismo, por 2 algarismos, com zero intercalado, com zero no final, ...)

\section{EXER.9 -}
( ) SIM
( ) QUASE INTEIRAMENTE
( ) POUCO
( ) NÃO

Os exercícios estão coerentes com o que foi trabalhado em sala de aula?
( ) SIM
( ) NÃO

\section{EXER.10 -}

O software caminha do básico ao profundo de forma suave?
( ) SIM
( ) $N \tilde{A} O$
( ) $\mathrm{NN}$

EXER.11 -

O quanto o software se aprofunda no conteúdo é considerado suficiente?
( ) SIM
( ) NÃO

EXER.12 -

O software possibilita a revisão do conteúdo que já foi trabalhado?
( ) SIM
( ) NÃO

EXER.13-

O software permite modificações do conteúdo por parte do professor?
( ) SIM
( ) NÃO
( ) NN

\section{EXER.14 -}

O software possui exemplos, questões de revisão e definições necessárias para sanar dúvidas com relação aos pré-requisitos exigidos para sua utilização?
( ) SIM
( ) QUASE INTEIRAMENTE
( ) POUCO
( ) NÃO

\section{Apresentação dos Exercícios}

\section{EXER.15 -}

O software é objetivo na forma com que apresenta os exercícios, explicitando o(s) conceito(s) a ser(em) trabalhado(s), fazendo com que o aluno o(s) exercite a fim de que possa fixá-lo(s) adequadamente?
( ) SIM
( ) QUASE INTEIRAMENTE
( ) POUCO
( ) NÃO

\section{EXER.16 -}

Os exercícios propostos pelo software permitem uma variedade de possibilidades de aplicação do conceito a ser trabalhado?
( ) SIM
( ) QUASE INTEIRAMENTE
( ) POUCO
( ) NÃO 
EXER.17 -

Os exercícios propostos pelo software são, sempre que possível, representativos da realidade do aluno?
( ) SIM
( ) QUASE INTEIRAMENTE
( ) POUCO
( ) $\mathrm{NÃO}$

\section{EXER.18 -}

Os exercícios propostos são variados e apresentados de forma interessante?
( ) SIM
( ) QUASE INTEIRAMENTE
( ) POUCO
( ) $\mathrm{NÃO}$

\section{EXER.19-}

Os exercícios apresentados são desafiadores, levando em conta o nível de dificuldade do conteúdo a ser trabalhado e a idade do aluno que irá utilizar o software?
( ) SIM
( ) QUASE INTEIRAMENTE
( ) POUCO
( ) NÃO

\section{EXER.20 -}

Os exercícios apresentados são criativos e bem elaborados?
( ) SIM
( ) QUASE INTEIRAMENTE
( ) POUCO
( ) NÃO

\section{EXER.21 -}

$\mathrm{Na}$ apresentação dos exercícios, o software utiliza ao máximo os recursos da máquina? (som, imagem, animação etc)
( ) SIM
( ) QUASE INTEIRAMENTE
( ) POUCO
( ) NÃO

\section{EXER.22 -}

O software oferece a opção de imprimir o exercício e a resposta, caso o professor considere necessário?
( ) SIM
( ) NÃO
( ) NN

\section{Apresentação de problemas}

Caso o software aborde o conhecimento matemático com o objetivo de ser aplicado na resolução de problemas rotineiros e não rotineiros, as questões de EXER.23 a EXER.23.5 devem ser respondidas.

\section{EXER.23 -}

O software propõe problemas?
( ) SIM
( ) $\mathrm{NÃO}$

Se Sim, responda:

EXER.23.1 - O software propõe problemas envolventes e desafiadores, de acordo com a faixa etária a que se destina?
( ) SIM
( ) QUASE INTEIRAMENTE
( ) POUCO
( ) NÃO 
EXER.23.2 - O software propõe problemas significativos, que dizem respeito a realidade do aluno?
( ) SIM
( ) QUASE INTEIRAMENTE
( ) POUCO
( ) NÃO

EXER.23.3 - O software possibilita que o aluno formule hipóteses?
( ) SIM
( ) QUASE INTEIRAMENTE
( ) POUCO
( ) NÃO

EXER.23.4 - O software possibilita vários caminhos para a solução dos problemas?
( ) SIM
( ) QUASE INTEIRAMENTE
( ) POUCO
( ) NÃO

EXER.23.5 - O esquema utilizado pelo software para direcionar a criança à resolução do problema é adequado?
( ) SIM
( ) QUASE INTEIRAMENTE
( ) POUCO
( ) NÃO

\section{Usabilidade}

\section{EXER.24 -}

As orientações dadas pelo software sobre sua forma de utilização são claras e fáceis de serem entendidas?
( ) SIM
( ) QUASE INTEIRAMENTE
( ) POUCO
( ) NÃO

\section{EXER.25 -}

O software evita conter informações irrelevantes ou raramente necessárias?
( ) SIM
( ) NÃO

\section{EXER.26 -}

Os enunciados dos exercícios propostos permitem que o aluno entenda o que está sendo pedido?
( ) SIM
( ) QUASE INTEIRAMENTE
( ) POUCO
( ) NÃO

EXER.27 -

O software permite que "sessões" interrompidas sejam reiniciadas a partir do "ponto de parada"?
( ) SIM
( ) NÃO 


\section{FEEDBACK}

\section{EXER.28 -}

Qual é a forma de feedback emitida pelo software, quando o aluno erra a resposta do exercício proposto? aluno.

( ) REPETIÇÃO - simplesmente reapresenta a pergunta anteriormente feita ao

( ) PISTA - fornece uma mensagem na intenção de chamar a atenção do aluno sobre o fundamento do erro cometido, com o objetivo de fazer com que o aluno descubra o que "implicitamente" já sabe.

( ) EXPLICAÇÃO ATRAVÉS DE MENSAGEM PADRÃO - fornece uma única mensagem de explicação para todo e qualquer erro, no sentido de simplesmente "não ser a resposta correta".

( ) EXPLICAÇÃO EM FUNÇÃO DA RESPOSTA DO ALUNO - a resposta do aluno é analisada na sua originalidade e uma explicação é colocada de acordo com esta resposta.

EXER.29 -

O feedback realizado pelo software permite que o aluno reflita sobre seu erro e tente corrigi-lo, sem intervenção ostensiva do professor?
( ) SIM
( ) QUASE INTEIRAMENTE
( ) POUCO
( ) NÃO

\section{EXER.30 -}

Você considera a forma de feedback emitida pelo software adequada?
( ) SIM
( ) NÃO

\section{EXER.31 -}

As respostas do aluno são verificadas corretamente?
( ) SIM
( ) NÃO

\section{EXER.32 -}

O software justifica suas ações ou raciocínios envolvidos? (Quando, por exemplo, mostrar ao aluno a forma de resolução de algum exercício)
( ) SIM
( ) NÃO

EXER.32.1 - Se SIM, as ações ou raciocínios são justificados corretamente?
( ) SIM
( ) NÃO

\section{DESEMPENHO DO ALUNO}

\section{EXER.33 -}

O software oferece um relatório ao aluno sobre seu desempenho ao final de cada sessão, apresentando o número de respostas erradas, corretas, etc?
( ) SIM
( ) SIM, MAS COM POUCAS INFORMAÇÕES
( ) NÃO 


\section{EXER.34 -}

O software oferece ao professor a possibilidade de obter um relatório sobre o desempenho de cada aluno e/ou da turma no geral? (número de respostas certas, número de respostas erradas, número de tentativas de acerto, etc)
( ) SIM
( ) SIM, MAS COM POUCAS INFORMAÇÕES
( ) NÃO

EXER.35 -

O software oferece ao professor um histórico de utilização por parte do aluno? (número de sessões que o aluno realizou, tempo gasto em cada exercício ou cada módulo, etc)
( ) SIM
( ) SIM, MAS COM POUCAS INFORMAÇÕES
( ) NÃO
( ) NN 
VI.II.III.II QUESTÕES - CARACTERÍSTICAS PEDAgÓGICAS "TUTORIAL"

(A sigla NN significa "Não é Necessário para este produto")

\section{Vocabulário}

TUT.1 -

A linguagem utilizada está no nível de compreensão do aluno? (vocabulário, metáforas, etc)
( ) SIM
( ) $\mathrm{NÃO}$

TUT.2 -

O vocabulário é adequado, sem deixar de ser científico quando necessário?
( ) SIM
( ) QUASE INTEIRAMENTE
( ) POUCO
( ) NÃO

TUT.3 -

O tutorial utiliza termos iguais com significados diferentes?

TUT.4 -
( ) NÃO
( ) SIM

O tutorial utiliza termos diferentes com o mesmo significado?
( ) NÃO
( ) SIM

\section{Conceitos Matemáticos}

TUT.5 -

Os conceitos matemáticos definidos pelo tutorial estão corretos?
( ) SIM
( ) NÃO

TUT.6 -

Os conceitos matemáticos definidos pelo tutorial são precisos, ou seja, os conceitos são definidos de forma clara, sem utilização de palavras ambíguas?
( ) SIM
( ) NÃO

TUT.7 -

Os conceitos são colocados de forma adequada, utilizando, sempre que possível, estratégias de simulação ou mesmo de jogos, histórias motivadoras, a fim de ganhar a atenção do aluno?
( ) SIM
( ) QUASE INTEIRAMENTE
( ) POUCO
( ) NÃO 
TUT.8-

Os exemplos são representativos dos conceitos a que se referem?
( ) SIM
( ) QUASE INTEIRAMENTE
( ) POUCO
( ) NÃO

TUT.9-

As notações são adequadas e coerentes com as utilizadas pelo professor em sala de aula?
( ) SIM
( ) NÃO

\section{Conteúdo}

TUT.10 -

O tutorial é abrangente no sentido de abordar o máximo possível dentro do assunto a ser trabalhado, e coincide com a organização do currículo adotado na escola?
( ) SIM
( ) QUASE INTEIRAMENTE
( ) POUCO
( ) NÃO

TUT.11-

Se o tutorial abordar o assunto a ser trabalhado de forma mais abrangente do que o adotado na escola, você se considera no momento preparado para utilizá-lo?
( ) SIM
( ) QUASE INTEIRAMENTE
( ) POUCO
( ) NÃO
( ) NN

TUT.12-

O tutorial caminha do básico ao profundo de forma suave?
( ) SIM
( ) NÃO

TUT.13-

O tutorial permite a revisão do conteúdo que já foi trabalhado?
( ) SIM
( ) NÃO

TUT.14 -

O tutorial permite modificações do conteúdo por parte do professor?

TUT.15 -
( ) SIM
( ) NÃO
( ) NN

O tutorial possui uma base de dados com conhecimentos enciclopédicos sobre o domínio (assunto a ser trabalhado)?
( ) SIM
( ) NÃO

TUT.16-

O tutorial possui exemplos, questões de revisão e definições necessárias para sanar dúvidas com relação aos pré-requisitos exigidos para sua utilização?
( ) SIM
( ) QUASE INTEIRAMENTE
( ) POUCO
( ) NÃO 


\section{TUT.17 -}

O tutorial permite que o conteúdo seja particularizado para cada aluno, ou seja, permite que o conteúdo a ser abordado seja limitado de acordo com o que se deseja trabalhar com cada aluno individualmente?
( ) SIM
( ) NÃO
( ) NN

\section{Exercicios}

\section{TUT.18-}

Os exercícios propostos pelo tutorial são representativos da realidade do aluno, sempre que possível?
( ) SIM
( ) QUASE INTEIRAMENTE
( ) POUCO
( ) NÃO

TUT.19-

Os enunciados dos exercícios propostos permitem que o aluno entenda o que está sendo pedido?
( ) SIM
( ) QUASE INTEIRAMENTE
( ) POUCO
( ) NÃO

TUT.20 -

Os exercícios propostos são variados e apresentados de forma interessante?
( ) SIM
( ) QUASE INTEIRAMENTE
( ) POUCO
( ) NÃO

\section{TUT.21 -}

$\mathrm{Na}$ apresentação dos exercícios o software utiliza ao máximo os recursos da máquina? (som, imagem, animação, ...)
( ) SIM
( ) QUASE INTEIRAMENTE
( ) POUCO
( ) NÃO

TUT.22 -

Há um equilíbrio entre o conteúdo exposto e os exercícios propostos?
( ) SIM
( ) QUASE INTEIRAMENTE
( ) POUCO
( ) NÃO

TUT.23 -

O tutorial pode gerar problemas dinamicamente levando em conta as necessidades do aprendiz? (O software gera um modelo do aprendiz e a partir deste modelo pode criar problemas dinamicamente)
( ) SIM
( ) NÃO 


\section{Apresentação de problemas}

Caso o tutorial aborde o conhecimento matemático com o objetivo de ser aplicado na resolução de problemas rotineiros e não rotineiros, as questões de TUT.24 a TUT.24.5 devem ser respondidas.

TUT.24 -

O tutorial propõe problemas?
( ) SIM
( ) NÃO

Se Sim, responda:

TUT.24.1 - O tutorial propõe problemas envolventes e desafiadores, de acordo com a faixa etária a que se destina?
( ) SIM
( ) QUASE INTEIRAMENTE
( ) POUCO
( ) NÃO

TUT.24.2 - O tutorial propõe problemas significativos, que dizem respeito a realidade do aluno?
( ) SIM
( ) QUASE INTEIRAMENTE
( ) POUCO
( ) NÃO

TUT.24.3 - O tutorial possibilita que o aluno formule hipóteses?
( ) SIM
( ) QUASE INTEIRAMENTE
( ) POUCO
( ) $\mathrm{NÃO}$

TUT.24.4 - O tutorial possibilita vários caminhos para a solução dos problemas?
( ) SIM
( ) QUASE INTEIRAMENTE
( ) POUCO
( ) NÃO

TUT.24.5 - O esquema utilizado pelo tutorial para direcionar a criança à resolução do problema é adequado?
( ) SIM
( ) QUASE INTEIRAMENTE
( ) POUCO
( ) NÃO

\section{Usabilidade}

TUT.25 -

As orientações dadas pelo tutorial sobre sua forma de utilização são claras e fáceis de serem entendidas?
( ) SIM
( ) QUASE INTEIRAMENTE
( ) POUCO
( ) NÃO

TUT.26 -

O tutorial é objetivo, ou seja, possui um caminho objetivo que direciona o aluno para onde deve ir após a etapa em que se encontra, fazendo com que ele não se perca?
( ) SIM
( ) QUASE INTEIRAMENTE
( ) POUCO
( ) NÃO 
TUT.27 -

O tutorial permite que "sessões" interrompidas sejam reiniciadas a partir do "ponto de parada"?
( ) SIM
( ) NÃO

\section{Feedback}

TUT.28 -

Qual é a forma de feedback emitida pelo tutorial quando o aluno erra a resposta do exercício proposto?

( ) REPETIÇÃO - O tutorial simplesmente reapresenta a pergunta anteriormente feita ao aluno.

( ) PISTA - O tutorial fornece uma mensagem na intenção de chamar a atenção do aluno sobre o fundamento do erro cometido, com o objetivo de fazer com que o aluno descubra o que "implicitamente" já sabe.

( ) EXPLICAÇÃO ATRAVÉS DE MENSAGEM PADRÃO - O tutorial fornece uma única mensagem de explicação para todo e qualquer erro, no sentido de simplesmente "não ser a resposta correta".

( ) EXPLICAÇÃO EM FUNÇÃO DA RESPOSTA DO ALUNO - A resposta do aluno é analisada na sua originalidade e uma explicação é colocada de acordo com esta resposta.

TUT.29 -

O feedback realizado pelo tutorial permite que o aluno reflita sobre seu erro e tente corrigilo, sem intervenção ostensiva do professor?
( ) SIM
( ) QUASE INTEIRAMENTE
( ) POUCO
( ) NÃO

TUT.30 -

Você considera a forma de feedback emitida pelo tutorial adequada?
( ) SIM
( ) NÃO

TUT.31 -

As respostas do aluno são verificadas corretamente?
( ) SIM
( ) NÃO

\section{TUT.32 -}

O tutorial justifica suas ações ou raciocínios? (Quando, por exemplo, mostrar ao aluno a forma de resolução de algum exercício)
( ) SIM
( ) NÃO

TUT.32.1 -

Se SIM, as justificativas ou raciocínios estão corretamente empregados?
( ) SIM
( ) QUASE INTEIRAMENTE
( ) POUCO
( ) NÃO 
TUT.33 -

O tutorial consegue acessar e analisar as razões das respostas do aprendiz?

( ) SIM ( ) QUASE INTEIRAMENTE ( ) POUCO ( ) NÃO

\section{Desempenho do(s) aluno(s)}

TUT.34 -

O tutorial oferece um relatório sobre o desempenho do aluno para que seja possível verificar se os objetivos da lição foram alcançados? (número de respostas certas, número de respostas erradas para cada sessão, etc)
( ) SIM
( ) SIM, MAS
SOM POUCAS INFORMAÇÕES
( ) NÃO

TUT.35 -

O tutorial mantém um histórico de utilização por parte do aluno? (número de sessões que o aluno realizou, tempo gasto em cada módulo, etc)
( ) SIM
( ) SIM, MA
M POUCAS INFORMAÇÕES
( ) NÃO 
VI.II.III.III QUESTÕES - CARACTERÍSTICAS PEDAGÓGICAS "Jogo PEDAGóGICO"

(A sigla NN significa "Não é Necessário para este produto")

\section{Objetivo Educacional}

JOGO.1 -

O jogo possui um objetivo educacional matemático, mesmo que de modo implícito, ou seja, não declarado pelo produtor?
( ) SIM
( ) NÃO

JOGO.1.1 - Se SIM, ele atende ao objetivo educacional que está sendo proposto, ou seja, trabalha os aspectos necessários para atender ao objetivo proposto?
( ) SIM
( ) NÃO

\section{Vocabulário}

JOGO.2 -

A linguagem utilizada está no nível de compreensão do aluno? (vocabulário, metáforas, etc)
( ) SIM
( ) NÃO

\section{Conceitos Matemáticos}

JOGO.3 -

Os conceitos matemáticos embutidos no jogo estão corretos?
( ) SIM
( ) QUASE INTEIRAMENTE
( ) POUCO
( ) NÃO

\section{Conteúdo}

JOGO.4 -

O jogo leva em conta o que a criança pode (ou não) já conhecer, estando de acordo com a faixa etária a que se destina?
( ) SIM
( ) $\mathrm{NÃO}$

JOGO.5 -

A Matemática que está embutida no jogo é exatamente o que o professor pretende trabalhar com as crianças?
( ) SIM
( ) QUASE INTEIRAMENTE
( ) POUCO
( ) NÃO 
JOGO.6 -

O jogo será utilizado como uma revisão e/ou reforço para um assunto já trabalhado?
( ) SIM
( ) NÃO

JOGO.6.1 - Se SIM, a Matemática que está embutida nele é exatamente a que já foi trabalhada?

$$
\text { ( ) SIM ( ) NÃO }
$$

JOGO.7 -

Você acredita que o jogo ajudará a despertar o interesse do aluno pelo assunto?
( ) SIM
( ) QUASE INTEIRAMENTE
( ) POUCO
( ) NÃO

JOGO.8 -

O jogo apresenta uma síntese do que foi trabalhado, após o término de cada sessão?
( ) SIM
( ) NÃO
( ) NN

\section{Usabilidade}

JOGO.9 -

As orientações dadas pelo jogo sobre sua forma de utilização são claras e fáceis de serem entendidas?
( ) SIM
( ) QUASE INTEIRAMENTE
( ) POUCO
( ) NÃO

JOGO.10 -

Os objetivos do jogo estão claros e podem ser compreendidos pelo aluno facilmente?

JOGO.11 -
( ) SIM
( ) QUASE INTEIRAMENTE
( ) POUCO
( ) NÃO

O jogo permite que "sessões" interrompidas sejam reiniciadas a partir do "ponto de parada"?
( ) SIM
( ) NÃO

\section{Interatividade}

JOGO.12 -

O jogo possui uma grande possibilidade de interação com o aluno?
( ) SIM
( ) QUASE INTEIRAMENTE
( ) POUCO
( ) NÃO

JOGO.13 -

O jogo possui "detalhes" onde a criança possa explorar?
( ) SIM
( ) QUASE INTEIRAMENTE
( ) POUCO
( ) NÃO 


\section{Desafio}

JOGO.14 -

O jogo é inteligente, ou seja, não subestima a criança levando em conta a faixa etária em que ela se encontra?
( ) SIM
( ) QUASE INTEIRAMENTE
( ) POUCO
( ) NÃO

JOGO.15 -

O jogo possui dificuldades gradativas adequadas, ou seja, caminha do básico ao profundo de forma suave?
( ) SIM
( ) NÃO

JOGO.16-

O jogo possui uma lógica interna desafiadora mas, depois de descoberta, fácil de ser dominada pelo aluno?
( ) SIM
( ) QUASE INTEIRAMENTE
( ) POUCO
( ) NÃO

JOGO.17 -

O jogo explora a competição?
( ) SIM
( ) NÃO

JOGO.18 -

$\mathrm{Na}$ apresentação dos desafios o jogo utiliza ao máximo os recursos da máquina? (som, imagem, animação, etc)
( ) SIM
( ) QUASE INTEIRAMENTE
( ) POUCO
( ) NÃO

JOGO.19 -

O jogo permite que o aluno desenvolva estratégias de ação que lhe permitam ganhar com mais freqüência e/ou facilidade?
( ) SIM
( ) QUASE INTEIRAMENTE
( ) POUCO
( ) NÃO

\section{Aspectos Lúdicos}

JOGO.20 -

O jogo explora a Matemática de maneira lúdica?
( ) SIM
( ) QUASE INTEIRAMENTE
( ) POUCO
( ) NÃO

JOGO.21 -

O jogo oferece situações realistas relacionadas a situações matemáticas de forma natural sempre que possível?
( ) SIM
( ) QUASE INTEIRAMENTE
( ) POUCO
( ) NÃO 
JOGO.22 -

A Matemática está ligada ao assunto do jogo de forma intrínseca e não superficial?
( ) SIM
( ) QUASE INTEIRAMENTE
( ) POUCO
( ) NÃO JOGO.23 -

O jogo permite que o aluno perceba que está "trabalhando com Matemática"?
( ) SIM
( ) QUASE INTEIRAMENTE
( ) POUCO
( ) NÃO

\section{Aspectos Psicopedagógicos}

JOGO.24 -

O jogo, de alguma forma, pode motivar o questionamento na criança?
( ) SIM
( ) QUASE INTEIRAMENTE
( ) POUCO
( ) NÃO

JOGO.25 -

O jogo, de alguma forma, pode estimular a fantasia na criança?
( ) SIM
( ) QUASE INTEIRAMENTE
( ) POUCO
( ) NÃO

JOGO.26 -

O jogo, de alguma forma, pode estimular a curiosidade na criança?
( ) SIM
( ) QUASE INTEIRAMENTE
( ) POUCO
( ) NÃO

\section{Feedback}

JOGO.27 -

Qual é a forma de feedback emitida pelo jogo, quando o aluno erra? aluno.

( ) REPETIÇÃO - simplesmente reapresenta a situação anteriormente colocada ao

( ) PISTA - fornece uma mensagem na intenção de chamar a atenção do aluno sobre o fundamento do erro cometido, com o objetivo de fazer com que o aluno descubra o que "implicitamente" já sabe.

( ) EXPLICAÇÃO ATRAVÉS DE MENSAGEM PADRÃO - fornece uma única mensagem de explicação para todo e qualquer erro, no sentido de simplesmente "não ser o caminho ou reação correta".

( ) EXPLICAÇÃO EM FUNÇÃO DA RESPOSTA DO ALUNO - a atuação do aluno é analisada na sua originalidade e uma explicação é colocada de acordo com ela.

JOGO.28 -

O feedback realizado pelo jogo permite que o aluno reflita sobre seu erro e tente corrigi-lo, sem intervenção ostensiva do professor?
( ) SIM
( ) QUASE INTEIRAMENTE
( ) POUCO
( ) NÃO 
JOGO.29 -

Você considera a forma de feedback emitida pelo jogo adequada?
( ) SIM
( ) NÃO

JOGO.30 -

As respostas das crianças são verificadas corretamente?
( ) SIM
( ) NÃO

JOGO.31 -

O jogo oferece reforço positivo em momentos adequados?
( ) SIM
( ) QUASE INTEIRAMENTE
( ) POUCO
( ) NÃO

desempenho do aluno

JOGO.32 -

O jogo oferece feedback do progresso do aluno durante a sua utilização?
( ) SIM
( ) NÃO

JOGO.33 -

O jogo oferece um resumo do desempenho global do aluno no final do jogo?
( ) SIM
( ) NÃO

\section{Apresentação de problemas}

Caso o jogo aborde o conhecimento matemático com o objetivo de ser aplicado na resolução de problemas rotineiros e não rotineiros, as questões de JOGO.34 a JOGO.34.5 devem ser respondidas.

JOGO.34 -

O jogo propõe problemas?
( ) SIM
( ) NÃO

Se Sim, responda:

JOGO.34.1 - O jogo propõe problemas envolventes e desafiadores, de acordo com a faixa etária a que se destina?
( ) SIM
( ) QUASE INTEIRAMENTE
( ) POUCO
( ) NÃO

JOGO.34.2 - O jogo propõe problemas significativos, que dizem respeito à realidade do aluno?
( ) SIM
( ) QUASE INTEIRAMENTE
( ) POUCO
( ) NÃO

JOGO.34.3 - O jogo possibilita que o aluno formule hipóteses?
( ) SIM
( ) QUASE INTEIRAMENTE
( ) POUCO
( ) NÃO 
JOGO.34.4 - O jogo possibilita vários caminhos para a solução dos problemas?
( ) SIM
( ) QUASE INTEIRAMENTE
( ) POUCO
( ) NÃO

JOGO.34.5 - O esquema utilizado pelo jogo para direcionar a criança à resolução do problema é adequado?
( ) SIM
( ) QUASE INTEIRAMENTE
( ) POUCO
( ) NÃO

\section{Exercicios}

JOGO.35 -

O jogo propõe exercícios durante sua utilização?
( ) SIM
( ) NÃO

Se Sim, responda:

JOGO.35.1 - Os exercícios propostos pelo jogo são representativos da realidade do aluno, sempre que possível?
( ) SIM
( ) QUASE INTEIRAMENTE
( ) POUCO
( ) NÃO

JOGO.35.2 - Os enunciados dos exercícios propostos permitem que o aluno entenda o que está sendo pedido?
( ) SIM
( ) QUASE INTEIRAMENTE
( ) POUCO
( ) NÃO

JOGO.35.3 - Existe relação entre as atividades/jogadas realizadas durante o jogo e os exercícios propostos?
( ) SIM
( ) QUASE INTEIRAMENTE
( ) POUCO
( ) NÃO 


\section{VI.II.III.IV QUESTÕES - CARACTERÍSTICAS PEDAGÓGICAS "SIMULAÇÃO"}

(A sigla NN significa "Não é Necessário para este produto")

\section{Vocabulário}

SIMU.1 -

A linguagem utilizada está no nível de compreensão do aluno? (vocabulário, metáforas, etc)
( ) SIM
( ) $\mathrm{NAOO}$

\section{Conteúdo}

SIMU.2 -

O software de alguma forma pode motivar o interesse do aluno pelo assunto a ser trabalhado?
( ) SIM
( ) QUASE INTEIRAMENTE
( ) POUCO
( ) NÃO

SIMU.3 -

O software possui uma base de dados com conhecimentos enciclopédicos sobre o domínio (assunto a ser trabalhado)?
( ) SIM
( ) NÃO

\section{Usabilidade}

SIMU.4 -

As orientações dadas pelo software sobre sua forma de utilização são claras e fáceis de serem entendidas?
( ) SIM
( ) QUASE INTEIRAMENTE
( ) POUCO
( ) NÃO

SIMU.5 -

O software evita conter informações irrelevantes, ou raramente necessárias?
( ) SIM
( ) NÃO

SIMU.6-

O nível de dificuldade exposto pelo software é adequado à faixa etária a que se destina?
( ) SIM
( ) NÃO

SIMU.7-

É fácil reconhecer quando a simulação ou o teste para algumas hipóteses terminou?
( ) SIM
( ) QUASE INTEIRAMENTE
( ) POUCO
( ) NÃO 


\section{Testes}

SIMU.8 -

O software permite que o aluno teste suas próprias hipóteses?
( ) SIM
( ) NÃO

SIMU.9-

Os resultados apresentados são precisos?
( ) SIM
( ) NÃO

\section{Apresentaçãd}

SIMU.10 -

A relação da simulação com a realidade é o mais próximo possível do real?
( ) SIM
( ) QUASE INTEIRAMENTE
( ) POUCO
( ) NÃO

SIMU.11-

O software justifica suas ações ou raciocínios corretamente?
( ) SIM
( ) NÃO

SIMU.12-

A percepção do tempo que a simulação leva para ser realizada é adequada? (Nem muito rápida: "estou numa brincadeira"; nem muito lenta: "estou numa simulação".)
( ) SIM
( ) QUASE INTEIRAMENTE
( ) POUCO
( ) NÃO

\section{Aspectos Psicopedagógicos}

SIMU.13-

O software, de alguma forma, pode motivar o questionamento na criança?
( ) SIM
( ) QUASE INTEIRAMENTE
( ) POUCO
( ) NÃO

SIMU.14 -

O software, de alguma forma, pode estimular a curiosidade na criança?
( ) SIM
( ) QUASE INTEIRAMENTE
( ) POUCO
( ) $\mathrm{NÃO}$ 


\section{Feedback}

SIMU.15-

O software encaminha o aluno à instrução necessária para suprir deficiências em determinados assuntos, quando necessário? (Ex: quando o aluno coloca hipóteses sem sentido, o software capta a falta de domínio de certos elementos e o encaminha à instrução necessária para suprir tais deficiências.)
( ) SIM
( ) QUASE INTEIRAMENTE
( ) POUCO
( ) NÃO

SIMU.16-

Qual é a forma de feedback emitida pelo software, quando o aluno erra a resposta do exercício proposto? aluno.

( ) REPETIÇÃO - simplesmente reapresenta a pergunta anteriormente feita ao

( ) PISTA - fornece uma mensagem na intenção de chamar a atenção do aluno sobre o fundamento do erro cometido, com o objetivo de fazer com que o aluno descubra o que "implicitamente" já sabe.

( ) EXPLICAÇÃO ATRAVÉS DE MENSAGEM PADRÃO - fornece uma única mensagem de explicação para todo e qualquer erro, no sentido de simplesmente "não ser a resposta correta".

( ) EXPLICAÇÃO EM FUNÇÃO DA RESPOSTA DO ALUNO - a resposta do aluno é analisada na sua originalidade e uma explicação é colocada de acordo com esta resposta.

SIMU.17-

Você considera a forma de feedback emitida pelo software adequada?
( ) SIM
( ) NÃO 
VI.II.III.V QUESTÕES - CARACTERÍSTICAS PEDAGÓGICAS "SISTEMAS HIPERMÍDIA"

(A sigla NN significa "Não é Necessário para este produto")

\section{Fontes}

HIPER. 1 -

O sistema hipermídia está localizado em um site na Web?
( ) SIM
( ) NÃO

HIPER.1.1 - Se SIM, as fontes das informações são fidedígnas?
( ) SIM
( ) NÃO

\section{Interatividade}

HIPER.2 -

Qual o grau de interatividade que o sistema permite ao aluno?

( ) ALTO - permite a descoberta imprevista e a descoberta de exploração livre;

( ) MÉDIO - permite a descoberta guiada, assumindo um enfoque híbrido, ou seja, ora o aluno navega livremente, ora navega em caminhos pré-definidos;

( ) BAIXO - privilegia a aprendizagem, ou busca da informação, de recepção direcionada, ou seja, a exposição indutiva.

HIPER.3 -

Você considera o grau de interatividade do sistema adequado?
( ) SIM
( ) EM PARTE
( ) NÃO

\section{Vocabulário}

HIPER.4 -

A linguagem utilizada está no nível de compreensão do aluno? (vocabulário, metáforas, etc)
( ) SIM
( ) NÃO

HIPER.5 -

O vocabulário é adequado, sem deixar de ser científico, quando necessário?
( ) SIM
( ) NÃO

HIPER. 6 -

O sistema utiliza termos iguais com significados diferentes?
( ) NÃO
( ) SIM 
HIPER.7 -

O sistema utiliza termos diferentes com o mesmo significado?
( ) NÃO
( ) SIM

\section{Conceitos Matemáticos}

HIPER.8 -

Os conceitos matemáticos definidos pelo sistema estão corretos?
( ) SIM
( ) NÃO

HIPER.9 -

Os conceitos matemáticos definidos pelo sistema são precisos, ou seja, os conceitos são definidos de forma clara, sem utilização de palavras ambíguas?
( ) SIM
( ) NÃO

HIPER.10 -

Os conceitos são colocados de forma adequada, utilizando, sempre que possível, estratégias de simulação ou mesmo de jogos, histórias motivadoras, a fim de ganhar a atenção do aluno?
( ) SIM
( ) QUASE INTEIRAMENTE
( ) POUCO
( ) NÃO

HIPER.11 -

Os exemplos apresentados pelo sistema são representativos dos conceitos a que se referem?
( ) SIM
( ) QUASE INTEIRAMENTE
( ) POUCO
( ) NÃO

HIPER.12 -

As notações são adequadas e coerentes com as utilizadas pelo professor em sala de aula?
( ) SIM
( ) NÃO

\section{Conteúdo}

HIPER.13-

O conteúdo abordado no sistema se encaixa perfeitamente no que o professor pretende trabalhar com seus alunos?
( ) SIM
( ) NÃO

HIPER.14 -

O sistema é abrangente no sentido de abordar o máximo possível dentro do assunto a ser trabalhado, e coincide com a organização do currículo adotado na escola?
( ) SIM
( ) QUASE INTEIRAMENTE
( ) POUCO
( ) NÃO 
HIPER. 15 -

Se o sistema abordar o assunto a ser trabalhado de forma mais abrangente do que o adotado na escola, você se considera no momento preparado para utilizá-lo?
( ) SIM
( ) QUASE INTEIRAMENTE
( ) POUCO
( ) NÃO
( ) NN

HIPER.16 -

O conteúdo exposto pelo sistema é conciso e o mais objetivo possível? (Conciso no sentido de não possuir muitas informações secundárias, que podem ser promocionais ou publicitárias, gerando uma perda na credibilidade do sistema)
( ) SIM
( ) QUASE INTEIRAMENTE
( ) POUCO
( ) NÃO

\section{Usabilidade}

HIPER.17 -

É possível perceber facilmente o que é prioritário e o que é secundário no sistema?
( ) SIM
( ) QUASE INTEIRAMENTE
( ) POUCO
( ) NÃO

HIPER.18 -

O sistema proporciona facilidade de navegação?
( ) SIM
( ) QUASE INTEIRAMENTE
( ) POUCO
( ) NÃO

HIPER.19 -

O sistema dificulta que o aluno se perca com facilidade?
( ) SIM
( ) QUASE INTEIRAMENTE
( ) POUCO
( ) NÃO

HIPER.20 -

A quantidade de portas (links) oferecida pelo sistema é considerada adequada?
( ) SIM
( ) QUASE INTEIRAMENTE
( ) POUCO
( ) $\mathrm{NÃO}$

HIPER.21 -

O sistema possui modularidade das informações, ou seja, as informações são separadas por grupos?
( ) SIM
( ) NÃO

HIPER.22 -

O sistema contém um mapa de sua estrutura, de forma que o aluno possa saber onde está e para onde pode ir?
( ) SIM
( ) $\mathrm{NÃO}$

HIPER.22.1 - Se SIM, o mapa realmente auxilia na navegação?
( ) SIM
( ) QUASE INTEIRAMENTE
( ) POUCO
( ) NÃO 


\section{Exercícios}

HIPER.23 -

O sistema propõe exercícios?
( ) SIM
( ) NÃO

Se SIM, responda:

HIPER.23.1 - Os exercícios propostos pelo sistema são representativos da realidade do aluno, sempre que possível?
( ) SIM
( ) QUASE INTEIRAMENTE
( ) POUCO
( ) NÃO

HIPER.23.2 - Os enunciados dos exercícios propostos permitem que o aluno entenda o que está sendo pedido?
( ) SIM
( ) QUASE INTEIRAMENTE
( ) POUCO
( ) NÃO

HIPER.23.3 - Os exercícios propostos são variados e apresentados de forma interessante?
( ) SIM
( ) QUASE INTEIRAMENTE
( ) POUCO
( ) NÃO

HIPER.23.4 - Há um equilíbrio entre o conteúdo exposto e os exercícios propostos?
( ) SIM
( ) QUASE INTEIRAMENTE
( ) POUCO
( ) NÃO

HIPER.23.5 - Qual é a forma de feedback emitida pelo sistema quando o aluno erra a resposta do exercício proposto?

( ) REPETIÇÃO - O sistema simplesmente reapresenta a pergunta anteriormente feita ao aluno.

( ) PISTA - O sistema fornece uma mensagem na intenção de chamar a atenção do aluno sobre o fundamento do erro cometido, com o objetivo de fazer com que o aluno descubra o que "implicitamente" já sabe.

( ) EXPLICAÇÃO ATRAVÉS DE MENSAGEM PADRÃO - O sistema fornece uma única mensagem de explicação para todo e qualquer erro, no sentido de simplesmente "não ser a resposta correta".

( ) EXPLICAÇÃO EM FUNÇÃO DA RESPOSTA DO ALUNO - A resposta do aluno é analisada na sua originalidade e uma explicação é colocada de acordo com esta resposta.

HIPER.23.6 - O feedback realizado pelo sistema permite que o aluno reflita sobre seu erro e tente corrigi-lo, sem intervenção ostensiva do professor?
( ) SIM
( ) QUASE INTEIRAMENTE
( ) POUCO
( ) NÃO

HIPER.23.7 - Você considera a forma de feedback emitida pelo sistema adequada?
( ) SIM
( ) NÃO 


\section{Apresentação de problemas}

Caso o sistema aborde o conhecimento matemático com o objetivo de ser aplicado na resolução de problemas rotineiros e não rotineiros, as questões de HIPER.24 a HIPER.24.5 devem ser respondidas.

\section{HIPER.24 -}

O sistema propõe problemas?
( ) $\mathrm{SIM}$
( ) NÃO

Se Sim, responda:

HIPER.24.1 - O sistema propõe problemas envolventes e desafiadores, de acordo com a faixa etária a que se destina?
( ) SIM
( ) QUASE INTEIRAMENTE
( ) POUCO
( ) NÃO

HIPER.24.2 - O sistema propõe problemas significativos, que dizem respeito a realidade do aluno?
( ) SIM
( ) QUASE INTEIRAMENTE
( ) POUCO
( ) NÃO

HIPER.24.3 - O sistema possibilita que o aluno formule hipóteses?
( ) SIM
( ) QUASE INTEIRAMENTE
( ) POUCO
( ) NÃO

HIPER.24.4 - O sistema possibilita vários caminhos para a solução dos problemas?
( ) SIM
( ) QUASE INTEIRAMENTE
( ) POUCO
( ) NÃO

HIPER.24.5 - O esquema utilizado pelo sistema para direcionar a criança à resolução do problema é adequado?
( ) SIM
( ) QUASE INTEIRAMENTE
( ) POUCO
( ) NÃO

\section{Acesso às informações}

HIPER.25 -

O sistema possui rapidez de acesso às informações?
( ) SIM
( ) QUASE INTEIRAMENTE
( ) POUCO
( ) NÃO

HIPER.26 -

O sistema oferece facilidade para que o aluno siga referências?
( ) SIM
( ) QUASE INTEIRAMENTE
( ) POUCO
( ) NÃO

HIPER.27 -

O sistema expõe a data de sua última atualização?
( ) $\operatorname{SIM}$
( ) NÃO 
HIPER.28 -

Existe algum esquema oferecido pelo sistema para que os usuários sejam notificados sobre suas atualizações?
( ) SIM
( ) NÃO

HIPER.29 -

Há indícios de que o sistema é atualizado freqüentemente?
( ) SIM
( ) NÃO

\section{Aspectos Psicopedagógicos}

HIPER.30 -

O sistema pode estimular a curiosidade na criança?
( ) SIM
( ) QUASE INTEIRAMENTE
( ) POUCO
( ) NÃO

HIPER.31 -

O sistema pode incentivar a autonomia na criança?
( ) SIM
( ) QUASE INTEIRAMENTE
( ) POUCO
( ) NÃO

HIPER.32 -

O sistema pode incentivar a atividade de pesquisa/exploração?
( ) SIM
( ) QUASE INTEIRAMENTE
( ) POUCO
( ) NÃO

\section{Objetivos}

HIPER.33 -

O sistema permite que os alunos atinjam os mesmos objetivos mesmo seguindo caminhos diferentes?
( ) SIM
( ) QUASE INTEIRAMENTE
( ) POUCO
( ) NÃO 


\section{VI.II.IV Características Pedagógicas Relativas a Cada Ciclo do Ensino}

\section{Fundamental de Matemática}

A seguir apresentamos um conjunto de questões importantes na avaliação das características pedagógicas relativas aos objetivos propostos para cada um dos ciclos relativos ao Ensino Fundamental de Matemática. Estes questionários são baseados em [PCN97a], [PCN97b], [PCN97c] e [Onuchic99].

\section{VI.II.IV.I QUESTÕES - OBJETIVOS do "PrimeIRO CIClo do ENSINO FundAMENTAL DE MATEMÁTICA"}

PC.1 - O software explora o conhecimento matemático dentro da realidade do aluno, ou seja, do mundo a sua volta, a fim de que ele compreenda a Matemática como parte de sua vida cotidiana?
( ) SIM
( ) QUASE INTEIRAMENTE
( ) POUCO
( ) NÃO

PC.2 - O software pode auxiliar no desenvolvimento da confiança do aluno na própria capacidade de elaborar estratégias pessoais diante de situações-problema?
( ) SIM
( ) QUASE INTEIRAMENTE
( ) POUCO
( ) NÃO

PC.3 - O software valoriza a troca de experiências entre os alunos?
( ) SIM
( ) QUASE INTEIRAMENTE
( ) POUCO
( ) NÃO

PC.4 - O software realmente pode contribuir para que os objetivos traçados na questão EDU.1 (da parte de questões que abordam características pedagógicas gerais do produto de software) sejam satisfatoriamente alcançados?
( ) SIM
( ) QUASE INTEIRAMENTE
( ) POUCO
( ) NÃO 
VI.II.IV.II QUESTÕES - OBJetivos do "SEgundo CIClo do ENSINO FundAMENTAL DE MATEMÁTICA"

SC.1 - O software explora o conhecimento matemático dentro da realidade do aluno, ou seja, do mundo à sua volta, a fim de que ele compreenda a Matemática como parte de sua vida cotidiana?
( ) SIM
( ) QUASE INTEIRAMENTE
( ) POUCO
( ) NÃO

SC.2 - O software pode auxiliar no desenvolvimento da confiança da própria capacidade do aluno para propor e resolver problemas?
( ) SIM
( ) QUASE INTEIRAMENTE
( ) POUCO
( ) NÃO

SC.3 - O software pode auxiliar o desenvolvimento de características como perseverança, esforço e disciplina na busca de resultados por parte do aluno?
( ) SIM
( ) QUASE INTEIRAMENTE
( ) POUCO
( ) NÃO

SC.4 - O software pode ajudar o aluno no desenvolvimento de sua segurança ao defender seus argumentos?
( ) SIM
( ) QUASE INTEIRAMENTE
( ) POUCO
( ) NÃO

SC.5 - O software pode ajudar o aluno a desenvolver flexibilidade para modificar seus argumentos ao perceber que é necessário?
( ) SIM
( ) QUASE INTEIRAMENTE
( ) POUCO
( ) NÃO

SC.6 - O software valoriza o trabalho cooperativo e o intercâmbio de idéias como fonte de aprendizagem?
( ) SIM
( ) QUASE INTEIRAMENTE
( ) POUCO
( ) NÃO

SC.7 - O software explora a ordem na elaboração e apresentação de trabalhos por parte do aluno?
( ) SIM
( ) QUASE INTEIRAMENTE
( ) POUCO
( ) NÃO

SC.8 - O software explora a precisão na elaboração e apresentação de trabalhos por parte do aluno?
( ) SIM
( ) QUASE INTEIRAMENTE
( ) POUCO
( ) NÃO

SC.9 - O software explora a correção na elaboração e apresentação de trabalhos por parte do aluno?
( ) SIM
( ) QUASE INTEIRAMENTE
( ) POUCO
( ) NÃO

SC.10 - O software realmente pode contribuir para que os objetivos traçados na questão EDU.1 (da parte de questões que abordam características pedagógicas gerais do produto de software) sejam satisfatoriamente alcançados?
( ) SIM
( ) QUASE INTEIRAMENTE
( ) POUCO
( ) NÃO 
VI.II.IV.III QUestões - OBJetivos do "Terceiro Ciclo do Ensino Fundamental de MATEMÁTICA"

TC.1 - O software explora o conhecimento matemático dentro da realidade do aluno, ou seja, do mundo à sua volta, a fim de que ele compreenda a Matemática como parte de sua vida cotidiana?
( ) SIM
( ) QUASE INTEIRAMENTE
( ) POUCO
( ) NÃO

TC.2 - O software pode auxiliar o desenvolvimento na criança da capacidade de investigação e perseverança na busca de resultados?
( ) SIM
( ) QUASE INTEIRAMENTE
( ) POUCO
( ) NÃO

TC.3 - A atividade de compreensão na resolução de problemas por parte do aluno é valorizada?
( ) SIM
( ) QUASE INTEIRAMENTE
( ) POUCO
( ) NÃO

TC.4 - O software pode ajudar o desenvolvimento no aluno da capacidade de avaliar criticamente informações e opiniões que admitem uma análise Matemática?
( ) SIM
( ) QUASE INTEIRAMENTE
( ) POUCO
( ) NÃO

TC.5 - O software pode ajudar o desenvolvimento no aluno da capacidade de enfrentar situações-problema que exigem aplicação de conhecimentos matemáticos?
( ) SIM
( ) QUASE INTEIRAMENTE
( ) POUCO
( ) NÃO

TC.6 - O software permite diferentes formas de resolução de situações-problema?
( ) SIM
( ) NÃO

TC.6.1 - Se SIM, o software valoriza diferentes formas de resolução de situaçõesproblema?
( ) SIM
( ) QUASE INTEIRAMENTE
( ) POUCO
( ) $\mathrm{NA} O$

TC.7 - O software propõe estratégias de verificação de resultados por pelo aluno?
( ) SIM
( ) NÃO

TC.7.1 - Se SIM, o software valoriza o uso de estratégias de verificação de resultados pelo aluno?
( ) SIM
( ) QUASE INTEIRAMENTE
( ) POUCO
( ) NÃO

TC.8 - O software valoriza a predisposição do aluno para alterar uma estratégia prevista quando o resultado do problema não é satisfatório?
( ) SIM
( ) QUASE INTEIRAMENTE
( ) POUCO
( ) NÃO

TC.9 - O software expõe situações fazendo com que a criança valorize e use a linguagem Matemática para expressar-se com clareza, precisão e concisão?
( ) SIM
( ) QUASE INTEIRAMENTE
( ) POUCO
( ) NÃO 
TC.10 - O software explora aspectos relevantes da História da Matemática a fim de que o aluno reconheça sua relação com o desenvolvimento da humanidade?
( ) SIM
( ) QUASE INTEIRAMENTE
( ) POUCO
( ) NÃO

TC.11 - O software valoriza o trabalho cooperativo?
( ) SIM
( ) QUASE INTEIRAMENTE
( ) POUCO
( ) NÃO

TC.12 - O software valoriza a busca de informações por parte do aluno, na realização de uma atividade sempre que for necessário?
( ) SIM
( ) QUASE INTEIRAMENTE
( ) POUCO
( ) NÃO

TC.13 - O software valoriza a solicitação de assessoria por parte do aluno, na realização de uma atividade sempre que for necessário?
( ) SIM
( ) QUASE INTEIRAMENTE
( ) POUCO
( ) NÃO

TC.14 - O software valoriza o progresso pessoal do aluno?
( ) SIM
( ) QUASE INTEIRAMENTE
( ) POUCO
( ) NÃO

TC.15 - O software valoriza o progresso do grupo?
( ) SIM
( ) QUASE INTEIRAMENTE
( ) POUCO
( ) $\mathrm{NÃO}$

TC.16 - O software realmente pode contribuir para que os objetivos traçados na questão EDU.1 (da parte de questões que abordam características pedagógicas gerais do produto de software) sejam satisfatoriamente alcançados?
( ) SIM
( ) QUASE INTEIRAMENTE
( ) POUCO
( ) NÃO 
VI.II.IV.IV QUESTÕES - OBJETIVOS dO "QUARTO CIClO dO ENSINO FUnDAMENTAL DE MATEMÁTICA"

QC.1 - O software explora o conhecimento matemático dentro da realidade do aluno, ou seja, do mundo à sua volta, a fim de que ele compreenda a Matemática como parte de sua vida cotidiana?
( ) SIM
( ) QUASE INTEIRAMENTE
( ) POUCO
( ) NÃO

QC.2 - O software pode auxiliar o desenvolvimento na criança da capacidade de investigação e perseverança na busca de resultados?
( ) SIM
( ) QUASE INTEIRAMENTE
( ) POUCO
( ) NÃO

QC.3 - O software explora aspectos relevantes da História da Matemática a fim de que o aluno reconheça sua relação com o desenvolvimento da humanidade?
( ) SIM
( ) QUASE INTEIRAMENTE
( ) POUCO
( ) NÃO

QC.4 - O software valoriza o trabalho cooperativo?
( ) SIM
( ) QUASE INTEIRAMENTE
( ) POUCO
( ) NÃO

QC.5 - O software valoriza o progresso pessoal do aluno (no desenvolvimento de suas próprias capacidades)?
( ) SIM
( ) QUASE INTEIRAMENTE
( ) POUCO
( ) NÃO

QC.6 - O software valoriza a utilização de conhecimentos matemáticos como recursos para análise, interpretação e resolução de problemas em contextos do cotidiano da criança?
( ) SIM
( ) QUASE INTEIRAMENTE
( ) POUCO
( ) NÃO

QC.7 - O software valoriza o uso de estratégias de verificação e controle de resultados pelo aluno?
( ) SIM
( ) QUASE INTEIRAMENTE
( ) POUCO
( ) NÃO

QC.8 - O software apresenta e/ou aceita diferentes métodos e processos na resolução de um problema, a fim de que o aluno os compare e analise semelhanças e diferenças entre eles?
( ) SIM
( ) QUASE INTEIRAMENTE
( ) POUCO
( ) NÃO

QC.9 - O software pode ajudar o desenvolvimento no aluno da capacidade de avaliar criticamente informações e opiniões que admitem uma análise Matemática?
( ) SIM
( ) QUASE INTEIRAMENTE
( ) POUCO
( ) NÃO

QC.10 - O software realmente pode contribuir para que os objetivos traçados na questão EDU.1 (da parte de questões que abordam características pedagógicas gerais do produto de software) sejam satisfatoriamente alcançados?
( ) SIM
( ) QUASE INTEIRAMENTE
( ) POUCO
( ) NÃO 


\section{VI.III Questionário da Avaliação da Usabilidade do Produto de Software EdUCACIONAL de MATEMÁTICA DiRECIONADO ao ENSINO FundAMENTAL}

A seguir, apresentamos um conjunto de questões importantes na avaliação das características da usabilidade da interface, relativas ao produto de software educacional que está sendo avaliado. As questões estão agrupadas de acordo com as heurísticas nas quais se baseiam. A descrição de cada uma das heurísticas se encontra na Seção 4.3. Esta avaliação deve ser realizada por um conjunto de três a cinco alunos e dirigida pelo professor ou especialista da área educacional. O próprio orientador da avaliação pode assinalar a resposta levando em conta o que for colocado pelo aluno (a escala utilizada para as respostas possui um diferencial semântico). Este é o conjunto de questões a serem feitas pelo orientador aos alunos, durante a realização da avaliação:

HEURISTICA: AJUDA AOS USUÁRIOS NO RECONHECIMENTO, DIAGNÓSTICO E CORRECAO DE ERROS

HA.1 - Quando você faz alguma coisa errada e aparece uma mensagem dizendo que você errou e mostrando o que deve ser feito para arrumar o erro, você consegue entender estas instruções?
( ) extremamente
( ) razoavelmente
( ) ligeiramente
( ) neutro/não sei
( ) nenhum pouco/não

HA.1.1 - É fácil de fazer o que a mensagem sugere?
( ) extremamente
( ) razoavelmente
( ) ligeiramente
( ) neutro/não sei
( ) nenhum pouco/não

\section{HEURISTICA: CONTROLE DO USUÁRIO E LIBERDADE}

HC.1 - Você acha que é fácil corrigir um erro, quando por exemplo, você deseja refazer ou desfazer alguma coisa?
( ) extremamente
( ) razoavelmente
( ) ligeiramente
( ) neutro/não sei
( ) nenhum pouco/não 


\section{HEURÍSTICA: DOCUMENTACĀO E AJUDA AOS USUARIOS (LIMITADA A AJUDA ON LINE)}

HD.1 - Ao utilizar o sistema de ajuda (help), foi fácil encontrar a explicação para sua dúvida?
( ) extremamente
( ) razoavelmente
( ) ligeiramente
( ) neutro/não sei
( ) nenhum pouco/não

HD.1.1 - Esta explicação realmente o ajudou?
( ) extremamente
( ) razoavelmente
( ) ligeiramente
( ) neutro/não sei
( ) nenhum pouco/não

HD.2 - Foi fácil fazer o que o sistema de ajuda recomendou em relação a uma tarefa que você não havia conseguido realizar?
( ) extremamente
( ) razoavelmente
( ) ligeiramente
( ) neutro/não sei
( ) nenhum pouco/não

\section{HEURÍSTICA: RECONHECIMENTO AO INVÉS DA RECORREN NCIA À MEMÓRIA DO USUÁRIO}

HRec.1 - Quando você foi executar uma tarefa que já havia realizado antes, foi fácil lembrar como deveria ser feita?
( ) extremamente
( ) razoavelmente
( ) ligeiramente
( ) neutro/não sei
( ) nenhum pouco/não

HRec.2 - É fácil compreender a função de cada objeto colocado no software, ou seja, o que cada "coisa" faz?
( ) extremamente
( ) razoavelmente
( ) ligeiramente
( ) neutro/não sei
( ) nenhum pouco/não

HRec.3 - Você está achando fácil "navegar"? (questão específica para softwares do tipo sistema hipermídia)
( ) extremamente
( ) razoavelmente
( ) ligeiramente
( ) neutro/não sei
( ) nenhum pouco/não

HRec.4 - Você utilizou o mapa da estrutura do site? Foi fácil perceber onde você estava e como fazer para chegar onde você queria? (questão específica para softwares do tipo sistema hipermídia, localizados na web)
( ) extremamente
( ) razoavelmente
( ) ligeiramente
( ) neutro/não sei
( ) nenhum pouco/não 


\section{HEURÍSTICA: RELAÇÃO ENTRE O SISTEMA E O MUNDO REAL}

HRel.1 - Você está achando fácil de ler o que aparece na tela?
( ) extremamente
( ) razoavelmente
( ) ligeiramente
( ) neutro/não sei
( ) nenhum pouco/não

HRel.1.1 - Está sendo fácil de entender?
( ) extremamente
( ) razoavelmente
( ) ligeiramente
( ) neutro/não sei
( ) nenhum pouco/não

HRel.2 - Você está entendendo as palavras que aparecem na tela?
( ) extremamente
( ) razoavelmente
( ) ligeiramente
( ) neutro/não sei
( ) nenhum pouco/não

HRel.3 - Você está entendendo as frases que aparecem na tela?
( ) extremamente
( ) razoavelmente
( ) ligeiramente
( ) neutro/não sei
( ) nenhum pouco/não

HRel.4 - As orientações que o software dá sobre como utilizá-lo são fáceis de serem entendidas?
( ) extremamente
( ) razoavelmente
( ) ligeiramente
( ) neutro/não sei
( ) nenhum pouco/não

HRel.5 - Quando o software coloca uma definição (conceito) para algo da Matemática, você consegue entendê-la com facilidade?
( ) extremamente
( ) razoavelmente
( ) ligeiramente
( ) neutro/não sei
( ) nenhum pouco/não

HRel.5.1 - As palavras que ele utiliza são fáceis de serem entendidas?
( ) extremamente
( ) razoavelmente
( ) ligeiramente
( ) neutro/não sei
( ) nenhum pouco/não

HRel.6 - Você consegue entender o quê os exercícios pedem para você fazer? (questão específica para softwares dos tipos: exercício e prática, tutorial, jogo pedagógico e hipermídia - caso estes dois últimos apresentem exercícios)
( ) extremamente
( ) razoavelmente
( ) ligeiramente
( ) neutro/não sei
( ) nenhum pouco/não

HRel.7 - Quando o software mostra como foi feito algum exercício, você entende as palavras que ele usa? (questão específica para softwares dos tipos: exercício e prática e tutorial)
( ) extremamente
( ) razoavelmente
( ) ligeiramente
( ) neutro/não sei
( ) nenhum pouco/não 
HRel.8 - Você entendeu, com tranqüilidade, as instruções sobre onde deve chegar para ganhar o jogo? (questão específica para softwares do tipo jogo pedagógico)
( ) extremamente
( ) razoavelmente
( ) ligeiramente
( ) neutro/não sei
( ) nenhum pouco/não

HRel.9 - Você consegue dominar o conjunto de regras do jogo com facilidade? (questão específica para softwares do tipo jogo pedagógico)
( ) extremamente
( ) razoavelmente
( ) ligeiramente
( ) neutro/não sei
( ) nenhum pouco/não

\section{HEURISTICA: SIMPLICIDADE E ESTÉTICA DO SISTEMA}

HSi.1 - Você consegue encontrar na tela, com facilidade, onde deve "clicar" para realizar alguma tarefa?
( ) extremamente
( ) razoavelmente
( ) ligeiramente
( ) neutro/não sei
( ) nenhum pouco/não

HSi.2 - Você acha que o software utiliza cores bonitas e "harmoniosas"?
( ) extremamente
( ) razoavelmente
( ) ligeiramente
( ) neutro/não sei
( ) nenhum pouco/não

HSi.3 - É fácil entender qual o caminho que deve ser seguido para ir de uma etapa para outra? (questão específica para softwares do tipo tutorial)
( ) extremamente
( ) razoavelmente
( ) ligeiramente
( ) neutro/não sei
( ) nenhum pouco/não

HSi.4 - Você acha que é fácil perceber quando o software mostra que a simulação terminou? (questão específica para softwares do tipo simulação)
( ) extremamente
( ) razoavelmente
( ) ligeiramente
( ) neutro/não sei
( ) nenhum pouco/não

\section{HEURÍSTICA: SATISFACÃO SUBJETIVA}

HSa.1 - Você gosta de como o software apresenta suas atividades?
( ) extremamente
( ) razoavelmente
( ) ligeiramente
( ) neutro/não sei
( ) nenhum pouco/não

HSa.2 - Você tem vontade de usar várias outras vezes este software?
( ) extremamente
( ) razoavelmente
( ) ligeiramente
( ) neutro/não sei
( ) nenhum pouco/não 
HSa.3 - As músicas são agradáveis?
( ) extremamente
( ) razoavelmente
( ) ligeiramente
( ) neutro/não sei
( ) nenhum pouco/não

HSa.4 - Os desenhos (animação) são "legais" ou "bem feitos (elaborados)"?
( ) extremamente
( ) razoavelmente
( ) ligeiramente
( ) neutro/não sei
( ) nenhum pouco/não

HSa.5 - A(s) voz(es) é(são) agradável(is)?
( ) extremamente
( ) razoavelmente
( ) ligeiramente
( ) neutro/não sei
( ) nenhum pouco/não

HSa.6 - Quando você manda o software fazer alguma coisa, você acha que ele é rápido demais, demora muito ou faz em um tempo bom?
( ) rápido demais
( ) tempo bom
( ) demora muito

HSa.7 - Você se interessou pelo assunto da Matemática que o software trata?
( ) extremamente
( ) razoavelmente
( ) ligeiramente
( ) neutro/não sei
( ) nenhum pouco/não

HSa.8 - Você achou o software divertido?
( ) extremamente
( ) razoavelmente
( ) ligeiramente
( ) neutro/não sei
( ) nenhum pouco/não

HSa.9 - Enfim, você gostou do software?
( ) extremamente
( ) razoavelmente
( ) ligeiramente
( ) neutro/não sei
( ) nenhum pouco/não 


\section{VI.IV Elaborando um Relatório Sobre o Software Avaliado}

Um relatório sobre o produto de software avaliado pode ser feito. O intuito do desenvolvimento deste relatório é fazer com que os pontos negativos e positivos do produto sejam relatados.

O relatório pode ser elaborado da seguinte forma:

1. Faça um cabeçalho com a identificação do produto e também do avaliador. O seguinte formato pode ser utilizado:

\section{RELATÓRIO SOBRE O SOFTWARE AVALIADO}

Software avaliado:

Produtor do software:

Descrição do produto:

$\begin{array}{llll}\text { Tipo: ( ) Exercício e Prática } & \text { ( ) Tutorial } & \text { ( ) Jogo Pedagógico }\end{array}$ Avaliador:

2. Estruture o relatório, utilizando o formato sugerido nas Figuras 6.4.1, 6.4.2, 6.4.3 e 6.4.4, levando em conta o tipo do software avaliado;

3. Classifique os requisitos de qualidade, colocados em cada questão dos questionários utilizados, como sendo necessários, unidimensionais ou atrativos, segundo o seu ponto de vista. A definição de cada tipo pode ser encontrada no Capítulo 2 deste documento;

4. Dentre os requisitos classificados como necessários ou unidimensionais, identifique aqueles que obtiveram respostas "negativas", quando avaliados. Desta forma, podem ser considerados como problemas encontrados no produto de software;

5. Dentre os requisitos encontrados no passo $\underline{4}$, avalie, de acordo com o seu ponto de vista, o grau de gravidade de cada um. Os problemas considerados com alto grau de gravidade (onde possivelmente os alunos serão prejudicados ou ficarão insatisfeitos 
com suas ocorrências) podem ser relacionados no relatório, sendo colocados dentro do subconjunto a que cada um pertence;

6. Dentre os requisitos classificados como necessários, identifique aqueles que obtiveram respostas "inteiramente positivas" quando avaliados. Estes podem ser relacionados, no relatório, como sendo requisitos necessários identificados no produto;

7. Dentre os requisitos classificados como atrativos ou unidimensionais, identifique aqueles que obtiveram respostas "inteiramente positivas" ou "quase inteiramente positivas" quando avaliados. Estes podem ser relacionados, no relatório, como sendo requisitos atrativos identificados no produto;

8. Por fim, um parecer geral, conclusivo, sobre o software avaliado pode ser descrito. Com isso, o relatório está pronto.

\section{CARACTERISTICAS TÉCNICAS}

จ Parecer quanto à EMBALAGEM e/ou DOCUMENTO DE DESCRIÇÃO DO PRODUTO

(considerando as questões: E.1 a E.2 e D.1.1 a D.1.27)

- Parecer quanto ao MANUAL DO USUÁRIO e às CARACTERÍSTICAS TÉCNICAS DO SOFTWARE (considerando as questões: M.1 a M.17 e S.1 a S.12)

Figura 6.4.1 - Estrutura do RELATÓRIO SOBRE o SOFTWARE AVALIADO 
CARACTERISTICAS RELACIONADAS AO AMBIENTE EDUCACIONAL

\section{Software do tipo - EXERCÍCIO E PRÁTICA}

- Parecer quanto aos OBJETIVOS do software

(considerando as questões: EDU.1 a EDU.4)

- Parecer quanto aos ASPECTOS DE USABILIDADE do software (considerando as questões: EDU.5 a EDU.25 e EXER.24 a EXER.27)

2 Parecer quanto ao(s) CONTEÚDO/CONCEITOS trabalhado(s) pelo software (considerando as questões: EDU.26 a EDU.31e EXER.5 a EXER.14)

- Parecer quanto ao VOCABULÁRIO utilizado pelo software (considerando as questões: EXER.1 a EXER.4)

จ Parecer quanto à APRESENTAÇÃO DE PROBLEMAS (considerando as questōes: EXER.23.1 a EXER.23.5)

D Parecer quanto ao desempenho do software em relação à APRESENTAÇÃO DOS EXERCÍCIOS (considerando as questões: EXER.15 a EXER.22)

จ Parecer quanto à forma de abordagem do software em relação ao DESEMPENHO DO ALUNO (considerando as questões: EXER.33 a EXER.35)

- Parecer quanto ao FEEDBACK proporcionado pelo software (considerando as questōes: EXER.28 a EXER.32.1)

จ Parecer quanto à PRATICIDADE do software (considerando as questões: EDU.32 a EDU.36)

\section{Software do tipo - TUTORIAL}

$\rightarrow$ Parecer quanto aos OBJETIVOS do software (considerando as questões: EDU.1 a EDU.4)

- Parecer quanto aos ASPECTOS DE USABILIDADE do software (considerando as questões: EDU.5 a EDU.25 e TUT.25 a TUT.27)

- Parecer quanto ao(s) CONTEÚDO/CONCEITOS trabalhado(s) pelo software (considerando as questões: EDU.26 a EDU.31 e TUT.5 a TUT.17)

- Parecer quanto ao VOCABULÁRIO utilizado pelo software (considerando as questões: TUT.1 a TUT.4)

จ Parecer quanto à APRESENTAÇÃO DE PROBLEMAS (considerando as questões: TUT.24 a TUT.24.5)

จ Parecer quanto ao desempenho do software em relação à APRESENTAÇÃO DOS EXERCÍCIOS (considerando as questões: TUT.18 a TUT.23)

- Parecer quanto à forma de abordagem do software em relação ao DESEMPENHO DO ALUNO (considerando as questões: TUT.34 a TUT.35)

- Parecer quanto ao FEEDBACK proporcionado pelo software (considerando as questões: TUT.28 a TUT.33)

จ Parecer quanto à PRATICIDADE do software (considerando as questões: EDU.32 a EDU.36)

Figura 6.4.2 - Estrutura do RELATÓRIO SOBRE O SOFTWARE AVALIAdO (CONT.) 
Software do tipo - JOGO PEDAGÓGICO

D Parecer quanto aos OBJETIVOS do software

(considerando as questões: EDU.1 a EDU.4 e JOGO.1)

จ Parecer quanto aos ASPECTOS DE USABILIDADE e INTERATIVIDADE do software

(considerando as questões: EDU.5 a EDU.25 e JOGO.9 a JOGO.13)

- Parecer quanto ao(s) CONTEÚDO/CONCEITOS trabalhado(s) pelo software (considerando as questões: EDU.26 a EDU.31 e JOGO.3 a JOGO.8)

จ Parecer quanto ao VOCABULÁRIO utilizado pelo software (considerando as questōes: JOGO.2)

จ Parecer quanto à APRESENTAÇÃO DE PROBLEMAS (considerando as questões: JOGO.34 a JOGO.34.5)

จ Parecer quanto ao desempenho do software em relação à APRESENTAÇÃO DOS EXERCícIOS (considerando as questões: JOGO.35 a JOGO.35.3)

- Parecer quanto à forma de abordagem do software em relação ao DESEMPENHO DO ALUNO (considerando as questões: JOGO.32 a JOGO.33)

- Parecer quanto ao FEEDBACK proporcionado pelo software (considerando as questões: JOGO.27 a JOGO.31)

จ Parecer quanto ao DESAFIO proporcionado pelo software (considerando as questões: JOGO.14 a JOGO.19)

$\checkmark$ Parecer quanto aos ASPECTOS LÚDICOS trabalhados no software (considerando as questões: JOGO.20 a JOGO.23)

$\rightarrow$ Parecer quanto aos ASPECTOS PSICOPEDAGÓGICOS contidos no software (considerando as questões: JOGO.24 a JOGO.26)

$\rightarrow$ Parecer quanto à PRATICIDADE do software (considerando as questões: EDU.32 a EDU.36)

Software do tipo - SIMULAÇÃO

D Parecer quanto aos OBJETIVOS do software (considerando as questões: EDU.1 a EDU.4)

$\rightarrow$ Parecer quanto aos ASPECTOS DE USABILIDADE do software (considerando as questões: EDU.5 a EDU.25 e SIMU.4 a SIMU.7)

- Parecer quanto ao(s) CONTEÚDO/CONCEITOS trabalhado(s) pelo software (considerando as questões: EDU.26 a EDU.31 e SIMU.2 a SIMU.3)

2 Parecer quanto ao VOCABULÁRIO utilizado pelo software (considerando as questões: SIMU.1)

จ Parecer quanto à APRESENTAÇÃO DA(S) SIMULAÇÃO(ÕES) (considerando as questões: SIMU.10 a SIMU.12)

2 Parecer quanto aos TESTES proporcionados pelo software (considerando as questões: SIMU.8 a SIMU.9)

จ Parecer quanto ao FEEDBACK proporcionado pelo software (considerando as questões: SIMU.15 a SIMU.17)

- Parecer quanto aos ASPECTOS PSICOPEDAGÓGICOS contidos no software (considerando as questões: SIMU.13 a SIMU.14)

จ Parecer quanto à PRATICIDADE do software (considerando as questões: EDU.32 a EDU.36)

FIGURA 6.4.3 - ESTRUTURA DO RELATÓRIO SOBRE O SOFTWARE AVALIADO (CONT.) 


\section{Software do tipo - SISTEMAS HIPERMÍDIA}

- Parecer quanto aos OBJETIVOS do software (considerando as questões: EDU.1 a EDU.4 e HIPER.33)

- Parecer quanto aos ASPECTOS DE USABILIDADE e INTERATIVIDADE do software (considerando as questōes: EDU.5 a EDU.25, HIPER.2 a HIPER.3 e HIPER.17 a HIPER.22.1)

จ Parecer quanto ao(s) CONTEÚDO/CONCEITOS trabalhado(s) pelo software (considerando as questōes: EDU.26 a EDU.31 e HIPER.13 a HIPER.16)

2) Parecer quanto ao VOCABULÁRIO utilizado pelo software (considerando as questões: HIPER.4 a HIPER.7)

จ Parecer quanto à APRESENTAÇÃ̈O DE PROBLEMAS (considerando as questões: HIPER.24 a HIPER.24.5)

P Parecer quanto ao desempenho do software em relação à APRESENTAÇÃO DE EXERCíCIOS (considerando as questões: HIPER.23 a HIPER.23.7)

จ Parecer quanto aos aspectos relacionados ao ACESSO ÀS INFORMAÇÕES e FONTES contidas no software (considerando as questões: HIPER.25 a HIPER.29)

จ Parecer quanto aos ASPECTOS PSICOPEDAGÓGICOS contidos no software (considerando as questões: HIPER.30 a HIPER.32)

$\rightarrow$ Parecer quanto à PRATICIDADE do software (considerando as questões: EDU.32 a EDU.36)

\section{PARECER QUANTO AO DESEMPENHO DO SOFTWARE EM RELACCÃO AOS OBJETIVOS PROPOSTOS} AO ENSINO DE MATEMÁTICA NO:

จ PRIMEIRO CICLO do ENSINO FUNDAMENTAL (considerando as questões: PC.1 a PC.4)

จ SEGUNDO CICLO do ENSINO FUNDAMENTAL (considerando as questões: SC.1 a SC.10)

จ TERCEIRO CICLO do ENSINO FUNDAMENTAL (considerando as questões: TC.1 a TC.16)

$\checkmark$ QUARTO CICLO do ENSINO FUNDAMENTAL (considerando as questões: QC.1 a QC.10)

\section{CARACTERISTICA "USABILIDADE"}

จ Parecer quanto à CARACTERÍSTICA USABILIDADE, DO PONTO DE VISTA DOS CINCO ALUNOS QUE AVALIARAM O PRODUTO DE SOFTWARE

(considerando as questões HA.1 a HA.11, HC.1, HD.1 a HD.2, HRec.1 a HRec.4, HRel.1 a HRel.9, HSi.1 a HSi.4 e HSa.1 a HSa.9)

\section{Parecer Geral, Conclusivo}

(considerações finais conclusivas são apresentadas)

FIGURA 6.4.4 - ESTRUTURA DO RELATÓRIO SOBRE O SOFTWARE AVALIADO (CONT.) 


\section{Capítulo 7}

\section{Conclusões e Trabalhos Futuros}

Matemática significa, em grego, "saber pensar" [Lima96]. Este atributo, ou seja, a nossa capacidade de realizar mentalmente aquilo que pretendemos (ou não) fazer, nos distingue de outras espécies. É possível que o computador se torne um recurso pedagógico poderoso e versátil, auxiliando o processo no desenvolvimento desta capacidade, por parte das crianças. Mas, para isto, é preciso não mistificá-lo como um método pedagógico em si. A Informática pode ser considerada um importante diferencial, desde que utilizada adequadamente, com embasamento e competência.

No conjunto Educação/Matemática/Informática, um componente a ser desenvolvido e/ou selecionado é o software educacional, pelo caráter de interação que possui entre o professor, o aluno, o conhecimento matemático a ser aprendido, o ferramental computacional, etc. Este contexto nos leva a apontar este item (software educacional) como de suma importância no que entendemos ser o ambiente educacional do presente e futuro, ressaltando a importância de que venha a criar condições interativas, que conjugue diversas linguagens e, principalmente, que conjugue de forma dinâmica Matemática e a realidade das crianças.

Nosso trabalho contribui na linha de qualidade dos produtos, apresentando um instrumento de avaliação da qualidade, na forma de questionário, para softwares educacionais de Matemática, direcionados ao Ensino Fundamental. Nele, buscamos abordar tanto aspectos técnicos como educacionais que, segundo especialistas, devem estar presentes na ferramenta a ser utilizada no processo de ensino-aprendizagem. Sendo assim, podemos colocar este instrumento como auxiliar na avaliação da qualidade 
destes produtos não apenas para pessoas ligadas à área educacional (professores, coordenadores pedagógicos, diretores, etc.), mas, também, para desenvolvedores de software educacional através do controle da qualidade dos produtos intermediários, durante o processo de seu desenvolvimento.

Ressaltamos a condição de nosso instrumento poder ser refinado/atualizado, e consequentemente melhorado, através de novas utilizações do questionário de julgamento do instrumento. Ou seja, a reaplicação das fases 3, 4, 5 e 6 da "Segunda Utilização do Método GQM" (descritas na Seção 5.2), tendo como base o instrumento atual.

Também, o processo utilizado no desenvolvimento deste instrumento possui um grande potencial para ser empregado na elaboração de instrumentos similares, destinados, inclusive, a outras áreas.

Como importantes diferenciais deste trabalho, em relação aos já existentes, destacamos:

- o amplo envolvimento de educadores, tanto na etapa de extração do conhecimento dos especialistas da área educacional (através da técnica Entrevista), como na etapa de refinamento do instrumento de avaliação gerado (através das avaliações de softwares educacionais de Matemática, realizadas por professores do Ensino Fundamental);

- o questionário para "Avaliação da Usabilidade da Interface do Produto". Este foi elaborado a fim de que problemas de usabilidade da interface do software sejam identificados por alguns usuários finais, os alunos. A base desta avaliação é um 
conjunto de heurísticas (ou princípios) de usabilidade. Ressaltamos sua importância pela dificuldade, ou até mesmo impossibilidade, de alguns atributos de usabilidade serem detectados apenas pelo professor. Como exemplo, a "satisfação subjetiva", ou seja, a satisfação e motivação que o aluno sente ao utilizar o software.

- a abordagem da questão referente a temas transversais;

- os questionamentos sobre a possibilidade dos conceitos matemáticos trabalhados pelo software serem relacionados com outros conceitos da própria Matemática e/ou com conceitos de outras disciplinas;

- as questões referentes aos objetivos da Matemática, no processo de ensinoaprendizagem, relativos a cada um dos ciclos do Ensino Fundamental.

Podemos destacar, também, alguns recursos relevantes desta ferramenta:

- os procedimentos para a avaliação geral e a avaliação da interface do software;

- a seqüência de instruções para elaboração de um relatório sobre o software avaliado; e,

- um glossário contendo os termos técnicos utilizados nos questionamentos.

A metodologia utilizada tanto para a elaboração do instrumento em si (abordagem GQM) como para a extração do conhecimento junto a especialistas (técnica Entrevista, de Aquisição de Conhecimento Explícito) e, para a avaliação da característica "usabilidade" (método da Avaliação Heurística), foi essencial no desenvolvimento do trabalho. Com isso foi possível traçar objetivos de forma estruturada e buscar alcançá-los de maneira disciplinada. 
Os objetivos traçados para este trabalho foram alcançados, tendo em vista, principalmente, o apoio de especialistas ligados à área educacional que contribuíram com valorosas informações. E, como já era esperado, dificuldades surgiram. Entre as principais, podemos destacar:

- o enfoque de aspectos exclusivos da Matemática, sem focalizarmos a abordagem de conteúdos específicos;

- a sintetização e relação das diversas informações colhidas junto aos especialistas (apesar da objetividade com que os entrevistados colocaram suas idéias);

- o agendamento dos professores para a aplicação do instrumento, com o objetivo de obter um feedback para seu refinamento;

- a dificuldade na aquisição dos softwares educacionais para as avaliações, apesar da variedade constatada em catálogos de distribuidores e em guias sobre estes produtos (muitos já não eram mais fabricados e outros não eram de fácil acesso);

- a complexidade do trabalho, por conta das diversas áreas que o envolveram (Matemática, Informática, Pedagogia, Psicologia).

Como principais limitações observadas em nosso instrumento, destacamos a necessidade dos possíveis usuários possuírem um conhecimento básico sobre:

- o assunto abordado nos produtos de software de Matemática; e,

- particularidades quanto à prática de ensino no nível fundamental (noções de Pedagogia, de Psicologia e de Educação Matemática). 
Não podemos esquecer, também, da importância da definição de objetivos a serem obtidos, com o apoio do produto de software educacional a ser analisado.

Como um possível trabalho futuro, podemos indicar a elaboração de uma ferramenta para automatizar o relatório sobre o software avaliado. A parte conceitual já foi feita, ou seja, um "algoritmo" ou "esquema lógico para o desenvolvimento do relatório sobre o software avaliado", como assim o chamamos. Este esquema possui 54 páginas e aborda as questões de múltipla escolha. As características consideradas como requisitos de qualidade necessários ou unidimensionais, são tratadas no esquema independente da resposta ao questionamento obtida. Já as características consideradas como requisitos de qualidade atrativos, são tratadas apenas se a resposta ao questionamento for favorável ao produto. A implementação desta ferramenta pode ser desenvolvida através de CGl's, para, assim, ser possível produzir o relatório via Internet. O avaliador insere suas respostas em formulários disponibilizados na Web. Através de CGl's, a ferramenta poderá elaborar um relatório com a mesma estrutura sugerida neste trabalho, para a elaboração manual do mesmo. Ressaltamos que uma limitação a ser trabalhada dentro desta ferramenta computadorizada, é que nem todas as questões abordadas podem ser compatíveis com a linha de pensamento pedagógico do avaliador.

Também, a validação do instrumento/questionário gerado com este trabalho, pode ser traçada como um futuro trabalho a ser realizado como continuidade a este. Para isto, é preciso verificar o sucesso do produto avaliado em atingir seus objetivos (aprendizado do aluno) nos moldes da prática de pedagogia.

Um outro possível trabalho, seria a elaboração de um instrumento similar ao gerado, dirigido ao Ensino Médio. 
Gostaríamos de sugerir que cursos relacionados à educação tivessem uma disciplina relativa ao projeto, avaliação e uso do software educacional. A sua importância se dá tanto pelo fato do processo de desenvolvimento deste tipo de produto envolver profissionais de diversas áreas (principalmente o educador), como pela tendência de aumento de sua utilização no sistema educacional como um todo.

Para finalizar, ressaltamos, segundo Magina [Magina98], que a exploração do potencial real do computador na educação necessita de mudanças significativas na maneira de ensinar e aprender das pessoas. A utilização desta ferramenta pode contribuir para a criação de um cenário diferente na educação. Este pode oferecer possibilidades ao aluno de construir uma ponte sólida entre os conceitos matemáticos e o mundo prático em que vive. Porém, por mais poderoso que seja, a intervenção do professor, seja por meio da elaboração de atividades ou no papel de agente mediador da aprendizagem, será sempre necessária. Portanto, longe da idéia de que o computador viria substituir o professor, seu uso vem, sobretudo, reforçar o papel dele na preparação, condução e avaliação do processo ensino-aprendizagem [PCN97c]. Cabe a ele, decidir o quê, quando, como e para quê utilizar as ferramentas que possui, em especial os softwares.

Destacamos, então, as palavras do Prof. Dr. Moacir Gadotti [Faerman99]: "... o professor é um dos profissionais mais importantes desta época ... os professores e jornalistas que amarem o conhecimento, os poetas que sentirem e transmitirem esse legado são insubstituíveis. Mas tem que ser com essa centelha, essa chama, essa generosidade, pelo prazer, pela alegria que dá o ato de conhecer. Só subsistirão assim, inclusive, porque a nova tecnologia só demite o professor que deixa a chama apagar". 


\section{BIBLIOGRAFIA}

[Abib98]

ABIB, J.C. Abordagem Goal Question Metric (GQM) para Avaliação da Qualidade de Software. São Carlos, 1998. Dissertação (Mestrado) - Centro de Ciências Exatas e de Tecnologia, Universidade Federal de São Carlos.

[Andersen97]

Andersen, P.B. A Theory of Computer Semiotics. Semiotic Approaches to Construction and Assessment of Computer Systems. Cambridge: Cambridge University Press, 1997.

[Andrade96]

ANDRADE, A.L.P.; OliveIRA, A.A.P.; CAPOVILLA, C.R.; RÊGO, C.M.; SOUZA, E.P.; MARTINEZ, M.R.M.; AGUAYO, M.T.V.; JINO, M. Aplicação da Norma ISO/IEC 12119 na Avaliação da Qualidade de Produtos de Software. In: VII CONFERÊNCIA INTERNACIONAL DE TECNOLOGIA DE SOFTWARE, Curitiba, Brasil, Junho, 1996. Anais.

[André95]

ANDRÉ, M.E.D.A. Etnografia da Prática Escolar. Papirus - Série Prática Pedagógica, 1995.

[Arantes99a]

ARANTES, J.T. Pane no Disco Rígido: Entrevista - Valdemar Setzer. Educação, Ed. Segmento, São Paulo, SP, Outubro, p.3-8, 1999.

[Arantes99b]

ARANTES, J.T. O Computador no Banco dos Réus - Debate entre Ana M. Nicolaci-daCosta e Valdemar Setzer. Galileu, Ed. Globo, Rio de Janeiro, RJ, Dezembro, p.40-2, 1999.

[Barbeiro99]

BARBEIRo, H. O Uso da Informática na Educação - Debate entre Eduardo Chaves e Valdemar Setzer - TV Cultura, 1999. Transcrição disponível em: http://www.edutecnet.com.br, 1999.

[Basili84]

BASILI, V.R.; WEISS, D.M. A Methodology for Collecting Valid Software Engineering Data. IEEE Transactions on Software Engineering, November, p.728-38, 1994.

[Basili88]

BASILI, V.R.; ROMBACH, H.D. The TAME Project: Towards Improvment-Oriented Software Environments. IEEE Transactions on Software Engineering, SE- n.14, v.6, 1988.

[Basili94]

BAsill, V.; Caldiera, G.; Rombach, D. The Goal Question Metric Approach. In: Encyclopedia of Software Engineering, 1994. 
[Basili95]

BASILI, V.R.; CaldieRA, G.; Rombach, H.D. Goal Question Metric Paradigm. In: Encyclopedia of Software Engineering, John Wiley \& Sons, New York, v.1, p.527-32, 1995.

[Baumgartner96]

BaumgartneR, P.; PayR, S. Learning as Action: A Social Science Approach to the Evaluation of Interactive Media, $1996 . \quad$ Disponivel em http://www.webcom.com/journal/baumgart.html, 1996.

[Belloquim97]

BELLOQUIM, A. Qualidade de Software: Um compromisso de toda empresa. Developers' Magazine, Ed. Axcel Books do Brasil, Rio de Janeiro, RJ, Junho, 1997.

[Boehm81]

BOHEM, B. Software Engineering Economics. Prentice Hall, 1981.

[Braga96]

BRAGA, C.M.S. Avaliação de Software Educacional Multimídia. In: VII SIMPÓsıo BRASILEIRO DE INFORMÁTICA NA EdUCAÇÃO, Belo Horizonte, Brasil, 1996. Anais. p.15161.

[Campos94a]

CAMPOS, F.C.A. Hipermídia na Educação: Paradigmas e Avaliação da Qualidade. Rio de Janeiro, 1994. Dissertação (Mestrado) - COPPE/Sistemas, Universidade Federal do Rio de Janeiro.

[Campos94b]

CAmpos, G.H.B. Metodologia para Avaliação da Qualidade de Software Educacional. Diretrizes para Desenvolvedores e Usuários. Rio de Janeiro, 1994. Tese (Doutorado) - Universidade Federal do Rio de Janeiro.

[Campos99a]

CAMPOS, F.C.A.; CAmpos, G.H.B.; RochA, A.R.C. Tradicionalismo $X$ Inovação: A Informática Educativa nas Escolas Brasileiras. In: WORKSHOP DE INFORMÁTICA NA EscolA, Rio de Janeiro, Brasil, 1999. Anais. p.613-25.

[Campos99b]

CAMPOS, F.C.A. Como Selecionar Software Educacional. Tutorial. In: V WORKSHOP DE INFORMÁTICA NA EsCOLA, Rio de Janeiro, Brasil, Julho, 1999.

[Campos99c]

CAMPOS, F.C.A.; RochA, A.R.C.; CAMPOS, G.H.B. Qualidade de Software Educacional: Uma Proposta. In: WORKSHOP QUALIDADE DE SOFTWARE, Florianópolis, Brasil, 1999. Anais. p.153-65.

[Carraher90]

CARRAHER, D.W. O Que Esperamos do Software Educacional. Acesso, São Paulo, Ano 2, n.3, Jan/Jul, p.32-6, 1990. 
[Chaves88]

Chaves, E.O.C.; Setzer, V.W. O Uso de Computadores em Escolas: Fundamentos e Críticas. Scipione, 1988. p.5-67.

[Collins94]

Collins, W.R.;Miller, K.W.; Spielman, B.J.; WherRY, P. How Good is Good Enough? Communications of the ACM, v.37, n.1, p.81-91, 1994.

[Cristovão97a]

CRIStovÃO, H.M. Ambientes Computacionais para Apoio à Aprendizagem: Um Experimento com Frações. Vitória, 1997. Dissertação (Mestrado) - Universidade Federal do Espírito Santo.

[Cristovão97b]

CRISTOVÃO, H.M. Um Modelo para Avaliação de Softwares Educativos. In: VIII SIMPÓsıO BRASILEIRO DE INFORMÁTICA NA EdUCAÇÃO, São José dos Campos, SP, 1997. Anais.

[CSR98]

ChILDREn's Software RevUE. Choosing Children's Software. In: Young Children \& Gomputers, A Parent's Survival Guide, $1998 . \quad$ Disponível em http://www.childrensoftware.com/evaluation.html.

[CTI97]

Fundação CENTRO TECNOLÓGICO PARA InFORMÁtICA. Programa de Qualidade e Produtividade em Software. Developers' Magazine, Ed. Axcel Books do Brasil, Rio de Janeiro, RJ, Junho, 1997.

[CTIOO]

FundaÇÃo CENTRO TECNOLÓGICO PARA INFORMÁtICA - INSTITUTO DE COMPUTAÇÃO, 2000. Disponível em http://halley.ic.cti.br/ic/pqps/.

[Dantas00]

DantAS, A.V.; CAStRo, A.F.; OliveiRA, I.R.; Oliveira, R.R. Crianças, Software, Aplicativos e seus Usos Educacionais. Folclore Multimídia. In: VI WORKSHOP DE INFORMÁTICA NA EDUCAÇÃO, Curitiba, PR, 2000. Anais.

[deLyra97]

DELYRA, J.L. Relatório de Participação como Representante da USP no Workshop on Leadership in Technology and Education, realizado na Universidade Carnegie Mellon, 1997. Disponível em http://www.ime.usp.br/ cci/impacto-ensino.

[Faerman99]

FAERmAn, M. Aula Magna: Entrevista - Moacir Gadotti. Educação, Ed. Segmento, São Paulo, SP, Fevereiro, p.3-6, 1999.

[Frant98]

FrANT, J.B. Tecnologias e Educação Matemática. Educação Matemática em Revista, SBEM, n.6, ano 5, p.19-20, 1998. 
[Freeman87]

FreEman,P. Software Perspectives - The System is the Message. Addison-Wesley Publishing Company. 1987.

[Gadotti94]

GADOTTI, M. História das Idéias Pedagógicas. Programa Nacional - Biblioteca do Professor. Ática, 1994.

[Galvis-Panqueva97]

Galvis-PANQUEVA, A.H. Software Educativo Multimídia: Aspectos Críticos no seu Ciclo de Vida. Revista Brasileira de Informática na Educação, Comissão Especial de Informática na Educação da Sociedade Brasileira de Computação, Florianópolis, SC, Setembro, p.9-18,1997.

[Gammack85]

Gammack, J.; Young, R. Psychological Techniques for Eliciting Expert Knowledge. In: M. Brarner, ed. Research and Development in Expert Systems. Cambridge University Press, 1985.

[Gardner94]

GARDNER, H. Estruturas da Mente: A Teoria das Inteligências Múltiplas. Artes Médicas, Porto Alegre, 1994.

[Giraffa00]

GIRAFFA, L.M.M. A Comunidade de Informática Educativa Brasileira: Perspectiva Histórica e Pesquisa. Painel Integrado de Palestras e Debates. In: VI WORKSHOP DE INFORMÁTICA NA ESCOLA, Curitiba, Brasil, Julho, 2000.

[Gladcheff99]

GladChefF, A.P. A utilização do Computador no Ensino de Matemática, Dirigido ao Ensino Fundamental: Características Psicopedagógicas do Software Educacional. Entrevista concedida pela Prof.a Dra Vera Barros de Oliveira, à mestranda Ana Paula Gladcheff. Instituto de Matemática e Estatística - IME/USP, São Paulo, 1999. Disponivel em http://www.ime.usp.br/dcc/posgrad/teses/anapaula.

[Gladcheff00a]

GladCHEFF, A.P. A utilização do Computador no Ensino de Matemática, Dirigido ao Ensino Fundamental: Características do Software Educacional. Entrevista concedida pela Prof.a Ana Maria Hessel, à mestranda Ana Paula Gladcheff. Instituto de Matemática e Estatística - IME/USP, São Paulo, 2000. Disponível em http://www.ime.usp.br/dcc/posgrad/teses/anapaula.

[GladcheffoOb]

GLADCHEFF, A.P. A utilização do Computador no Ensino de Matemática, Dirigido ao Ensino Fundamental: Características do Software Educacional. Entrevista concedida pela Prof.a Consuelo Fernandez, à mestranda Ana Paula Gladcheff. Instituto de Matemática e Estatística - IME/USP, São Paulo, 2000. Disponível em http://www.ime.usp.br/dcc/posgrad/teses/anapaula. 


\section{[Gladcheff00c]}

GLADCHEFF, A.P. A utilização do Computador no Ensino de Matemática, Dirigido ao Ensino Fundamental: Características do Software Educacional. Entrevista concedida pelo Prof. Josenilton deFranca, à mestranda Ana Paula Gladcheff. Instituto de Matemática e Estatística - IME/USP, São Paulo, 2000. Disponível em http://www.ime.usp.br/dcc/posgrad/teses/anapaula.

[Gladcheff00d]

GLAdCHEFF, A.P. A utilização do Computador no Ensino de Matemática, Dirigido ao Ensino Fundamental: Características do Software Educacional. Entrevista concedida pelo Prof. Dr Leônidas Brandão, à mestranda Ana Paula Gladcheff. Instituto de Matemática e Estatística - IME/USP, São Paulo, 2000. Disponível em http://www.ime.usp.br/dcc/posgrad/teses/anapaula.

[GladcheffO0e]

GladCHEFF, A.P. A utilização do Computador no Ensino de Matemática, Dirigido ao Ensino Fundamental: Características do Software Educacional. Entrevista concedida pela Prof.a Marília Basili, à mestranda Ana Paula Gladcheff. Instituto de Matemática e Estatística - IME/USP, São Paulo, 2000. Disponível em http://www.ime.usp.br/dcc/posgrad/teses/anapaula.

[Gladcheff0Of]

GladCHEFF, A.P. A Utilização do Computador no Ensino de Matemática, Dirigido ao Ensino Fundamental: Características do Software Educacional. Entrevista concedida pela Prof.a Dra Ruth Ribas Itacarambi, à mestranda Ana Paula Gladcheff. Instituto de Matemática e Estatística - IME/USP, São Paulo, 2000. Disponível em http://www.ime.usp.br/dcc/posgrad/teses/anapaula.

[Gladcheff00g]

GLADCHEFF, A.P. Projeto de Mestrado "Um Instrumento de Avaliação da Qualidade para Software Educacional de Matemática, Direcionado ao Ensino Fundamental". Departamento de Ciência da Computação - Instituto de Matemática e Estatística Universidade de São Paulo, 2000. Disponível em http://www.ime.usp.br/dcc/posgrad/teses/anapaula.

[Gresse]

GRESSE, C.; Holls, B.; WÜST, J. A Process Model for GQM - Based Measurement. University of Kaiserslautern, Germany. (Relatório Técnico STTI-95-04-E)

[Gresse96]

GRESSE, C.; Rombach, H.D; RUHE, G. A Practical Approach for Building GQM Based Measurement Programs Lessons Learned from Three Industrial Case Studies. Tutorial. In: X Simpósio Brasileiro de Engenharia de Software, São Carlos, São Paulo, Brasil, Outubro, 1996.

[Holmes99]

HolmES, W.N. The Myth of the Educational Computer. IEEE Computer, September, p.3642, 1999. 
[Ince90]

INCE, D. Software Metrics: Introduction. Information and Software Technology, v.32, May, p.297-303, 1990.

[ISO8402]

INTERNATIONAL ORGANIZATION FOR STANDARDIZATION, DIS 8402. Quality Vocabulary. ISO8402. 1994.

[ISO9000-3]

INTERNATIONAL ORGANIZATION FOR STANDARDIZATION E ASSOCIAÇÃO BRASILEIRA DE NORMAS TÉCNICAS. Diretrizes para aplicação da ISO9001 ao desenvolvimento, fornecimento e manutenção de software. NBR ISO 9000-3. 1993.

[ISO9001]

INTERNATIONAL ORGANIZATION FOR STANDARDIZATION. Quality system - Model for quality assurance in design/development, production, installation and servicing. ISO 9001. Março, 1987.

[ISO9126-1]

INTERNATIONAL ORGANIZATION FOR STANDARDIZATION. Information technology - Software quality characteristics and metrics - Part 1: Quality characteristics and subcharacteristics. ISO/IEC 9126-1. Janeiro, 1997 (Commitee Draft).

[ISO9126-2]

INTERNATIONAL ORGANIZATION FOR STANDARDIZATION. Information technology - Software quality characteristics and metrics - Part 2: External metrics. ISO/IEC 9126-2. Janeiro, 1997 (Working Draft).

[ISO9126-3]

INTERNATIONAL ORGANIZATION FOR STANDARDIZATION. Information technology - Software quality characteristics and metrics - Part 3: Internal Metrics. ISO/IEC 9126-3. Outubro, 1996 (Working Draft).

[ISO12119]

INTERNATIONAL ORGANIZATION FOR STANDARDIZATION. Information technology - Software packages - Quality requirements and testing. ISO/IEC 12119. Outubro, 1994.

[ISO14598-1]

INTERNATIONAL ORGANIZATION FOR STANDARDIZATION. Information technology - Software product evaluation - Part 1: General Overview. ISO/IEC 14598-1. Outubro, 1996.

[ISO14598-2]

INTERNATIONAL ORGANIZATION FOR STANDARDIZATION. Information technology - Software product evaluation - Part 2: Planning and Management. ISO/IEC 14598-2. Dezembro, 1996.

[ISO14598-3]

INTERNATIONAL ORGANIZATION FOR STANDARDIZATION. Information technology - Software product evaluation - Part 3: Process for Developers. ISO/IEC 14598-3. Julho, 1996. 
[ISO14598-4]

INTERNATIONAL ORGANIZATION FOR STANDARDIZATION. Information technology - Software product evaluation - Part 4: Process for Acquirers. ISO/IEC 14598-4. Setembro, 1996.

[ISO14598-5]

INTERNATIONAL ORgaNIZATION FOR STANDARDIZATION. Information technology - Software Product Evaluation - Part 5: Process for Evaluators. ISO/IEC 14598-5. Maio, 1996.

[ISO14598-6]

INTERNATIONAL ORGANIZATION FOR STANDARDIZATION. Information technology - Software Product Evaluation - Part 6: Evaluation Modules. ISO/IEC 14598-6. Agosto, 1996.

[Joly95]

JOLY, M.C.R.A. O Resgate Histórico dos Computadores na Educação: Fundamentos para Pesquisa e Aplicação Enquanto Tecnologia Educacional. In: Estudos Interdisciplinares numa Visão Contemporânea. Editora da Universidade São Francisco, EDUSF, p.6195, 1995.

[Kan95]

KAN, S.H. Metrics and Models in Software Quality Engineering. Addison-Wesley Publishing Company, 1995.

[Kay89]

KAY, R.H. A Practical and Theoretical Approach to Assessing Computer Attitudes: The Computer Attitude Measure. Journal on Research on Computing in Education, 1989.

[Kirner97]

KIRNER, T.G; ABIB, J.C. Inspection of Software Requirements Documents: A Pilot Study. In: XV ACM International Conference on System Documentation, Salt Lake City, UT, USA, 1997. Proceedings. p.161-71.

[kogure83]

KoGURE, M.; AKAO, Y. Quality Function Deployment and CWQC in Japan. Quality Progress, October, 1983.

[Laurel93]

LAuREL, B. Computer as a Theatre. Reading, Mass. Addison-Wesley, 1993.

[Leite96]

LEITE, A.S.; FERNANDES, C.T.; OMAR, N. Avaliação de Sistemas de Tutoria Inteligente. In: VII SIMPÓSIO BRASILEIRO DE INFORMÁTICA NA EdUCAÇÃO, UFMG, Belo Horizonte, MG, Novembro, 1996. Anais. p. 313-25.

[Lévy96]

LÉVY, P. O Que é o Virtual? Editora 34, 1996.

[Lima96]

LIMA, L.C.; RochA, R.A.M. Crônica Sobre a Inutilidade de um Dilema: Giz ou Computador? Revista de Educação - AEC, v.25, n.99, 1996. 
[Lopes98]

LOPES, R.C.W.; PINTO, S.A.M; VELOSO, A.F. A Informática como Instrumento na Prática Psicopedagógica (Institucional e Clínica). Revista de Psicopedagogia, v.17, n.44, 1998.

[Loureiro98]

LOUREIRO, C.L. Avaliação de Softwares Educativos: Procurando Romper as Barreiras da Ingenuidade. Fortaleza, 1998. Dissertação (Mestrado) - Faculdade de Educação, Universidade Federal do Ceará.

[Mace99]

MACE, E.; Aquino, M. Guia de Software Educacional 1999 - Edulink. Logon Informática Ltda, 1999.

[Machado87]

MACHADO, N.J. Matemática e Realidade. Cortez, 1987.

[Machado91]

MACHADO, N.J. Matemática e Língua Materna. Cortez, 1991.

[Machado93]

MACHADO, N.J. Interdisciplinaridade e Matemática. Pro-posições, v.4, n.1, 1993.

[Magina98]

MAGINA, S. O Computador e o Ensino da Matemática. Tecnologia Educacional, v.26, n.140, Jan/Fev/Mar, 1998.

[McCall77]

MCCALL, J.A.; RICHARDS, P.K.; WALTERS, G.F. Factors in Software Quality. RADC TR77-369, 1977.

[McGraw89]

McGraW, K.L.; Briggs, K.H. Knowledge Acquisition: Principles and Guidelines. Prentice Hall, 1989.

[MEC00]

MINISTÉRIO DA EDUCAÇÃO. Notícias - Junho/2000. Disponível em http://www.mec.gov.br, 2000.

[Monteiro93]

MONTEIRO, E.B.; GomES, F.R.S. Informática e Educação: Panorama da Área Segundo Artigos dos Periódicos Nacionais de Educação. Tecnologia Educacional, v.22, p.42-8, 1993.

[Moretto99]

MORETTO, V.P. Reflexões Construtivistas sobre Habilidades e Competências. Dois Pontos: Teoria \& Prática em Gestão Educacional, setembro, 1999. 
[Murine80]

MURINE, G.E. Applying Software Quality Metrics in the Requirements Analysis Phase of a Distributive System. In: Minnowbrook Workshop, New York, 1980. Proceedings.

[NBR12119]

AsSoCIAÇĀo BRASILEIRA DE NoRMAS TÉCNICAS. Tecnologia de Informação - Pacotes de Software - Teste e Requisitos de Qualidade. NBR 12119. Agosto, 1996. (Versão Brasileira da Norma ISO/IEC 12119).

[NBR13596]

ASSOCIAÇÃO BRASILEIRA DE NORMAS TÉCNICAS. Tecnologia de Informação - Avaliação de Produto de Software - Características de Qualidade e Diretrizes para o seu Uso. NBR 13596. Abril, 1996. (Versão Brasileira da Norma ISO/IEC 9126).

[Nielsen93]

NiELSEN, J. Usability Engineering. Academic Press, Cambridge, MA, 1993.

[Nielsen94]

NIELSEN, J. Heuristic Evaluation. In: Usability Inspection Methods. John Wiley, New York, 1994.

[Nielsen99]

Nielsen, J. Design Web Usability. New Riders Publishing, 1999.

[Oliveira84]

OliveIRA, J.B.A.; CHADWICK, C.B. Tecnologia Educacional: Teorias da Instrução. Vozes, Petrópolis, 1984.

[Oliveira87]

Oliveira, C.C. de ; Menezes, E.I.M; Moreira, M. Avaliação de Software Educativo. Tecnologia Educacional, v.16, p.50-54, 1987.

[Oliveira95]

OliveIRA, A.L.M. Processo de Software - Visão Global. CTI, Campinas, 1995. (Relatório Técnico Fundação CTI)

[Oliveira96]

OLIVEIRA, V.B. Informática em Psicopedagogia. Senac, 1996.

[Onuchic99]

ONUCHIC, L.L.R. Ensino-Aprendizagem de Matemática Através da Resolução de Problemas. UNESP, Rio Claro, SP, 1999.

[Papert85]

PAPERT, S. Logo: Computadores e Educação. Brasiliense, 1985.

[Papert94]

PAPERT, S. A Máquina das Crianças: Repensando a Escola na Era da Informática. Artes Médicas, Porto Alegre, 1994. 
[Paulk93]

PAULK, M.C.; CURTIS, B.; CHRISSIS, M.B. Capability Maturity Model, Version1.1. IEEE Software, Julho, 1993.

[PCN97a]

BRASIL. Secretaria de Educação Fundamental, (1997). Parâmetros Curriculares Nacionais: Introdução - Educação Fundamental. Brasília: MEC/SEF.

[PCN97b]

BRASIL. Secretaria de Educação Fundamental, (1997). Parâmetros Curriculares Nacionais: Matemática - Ensino de $1^{\mathrm{a}}$ à $4^{\mathrm{a}}$ série. Brasília: MEC/SEF.

[PCN97c]

BRASIL. Secretaria de Educação Fundamental, (1997). Parâmetros Curriculares Nacionais: Matemática - Ensino de $5^{\mathrm{a}}$ à $8^{\mathrm{a}}$ série. Brasília: MEC/SEF.

[Piaget73]

PIAGET, J. Biologia e Conhecimento. Vozes, Petrópolis, 1973.

[Pimentel89]

PIMENTEL, M.G.C. Sistemas de Hipertexto: Discussões de Uma Proposta. In: XXIII CONGRESSo NACIONAL DE InfORMÁtICA. Sucesu. São Paulo, Brasil, 1989. Anais.

[Pinto99]

PINTO, M.A.L. Computadores X Educadores. Revista de Psicopedagogia, v.18, n.47, 1999.

[Pressman97]

PRESSMAN, R.S. Software Engineering: a Practitioner's Approach. McGraw-Hill, 1997.

[Reiser94]

ReISER, R.A.; Kegelmann, H.W. Evaluating Instrucional Software: A Review and Critique of Current Methods. ETR\&D, v.42, n.3, p.63-69, 1994.

[Rocha00]

ROCHA, H.V.D.; BARANAUSKAS, M.C.C. Design e Avaliação de Interfaces HumanoComputador. Tutorial. In: Escola de Computação 2000, São Paulo, Brasil, Julho, 2000.

[Rombach91]

ROMBACH, H.D. Practical Benefits of Goal-Oriented Measurement. Software Reliability and Metrics, Elsevier Applied Science, 1991.

[Rout95]

ROUT, P.T. SPICE: A Framework for Software Process Assessment - Software Process Improvement and Practice, Pilot Issue, p. 57-68, 1995. 
[Sanches93]

SANCHES, R. A Influência do Software e de seu Processo de Manutenção no Esforço de Manutenção. São Paulo, 1993. Tese (Doutorado) - Faculdade de Economia, Administração e Contabilidade da Universidade de São Paulo.

[Saraiva98]

SARAIVA, T. Inovações na Educação Brasileira: "Um Salto para o Futuro". Tecnologia Educacional, v.26, n.140, p. 46-52, Jan/Fev/Mar, 1998.

[Setzer94]

SeTZer, V.W. Computadores na Educação: Porquê, Quando e Como. In: V SıMPósıo BRASILEIRO dE INFORMÁtICA NA EdUCAÇÃO, Porto Alegre, Brasil, 1994. Anais. p.21123.

[Shepperd92]

SHEPPERD, M. Products, Processes and Metrics. Information and Software Technology, v.34, n.10, 1992.

[Tarouco99]

TAROUCO, L.M.R. Computador na Educação, 1999. Disponível em http://penta2.ufrgs.br/edu3375/e33755992.htm7.

[Tsukumo95]

Tsukumo, A.N.; Andrade, A.N.P.; RÊGo, C.M.; Azevedo, G.F.; JinO, M.; Tutumi, R.; MAINTINGUER, S.T. Avaliação de Produto de Software: Algumas Questões Relevantes e a ISO/IEC 9126. In: WORKSHOP QUALIDADE DE SOFTWARE, Recife, Brasil, 1995. Anais. p.116-21.

[Tsukumo96]

Tsukumo, A.; Andrade, A.L.P.; RêGo, C.M.; Weller, D.; AzeVedo, G.F.; Tutumi, R.; MAINTINGUER, S.T. Qualidade de Software: Uma Visão Geral sobre Avaliação e Melhoria. I Concurso de Monografias, Qualidade e Produtividade em Software, São Carlos, Brasil, 1996.

[Tsukumo97]

Tsukumo, A.N.; RÊGo, C.M.; Salviano, C.F.; Azevedo, G.F.; Meneghetti, L.K.; Costa, M.C.C.; CARVAlHO, M.B.; ColomBo, R.M.T. Qualidade de Software: Visões de Produto e Processo de Software. In: VIII CITS - CONFERÊNCIA INTERNACIONAL DE TECNOLOGIA DE SofTWARE: QualidAdE DE SofTWARE, Curitiba, Paraná, Brasil, 1997. Anais.

[Valente91]

VALENTE, J.A. Usos do Computador na Educação. Campinas, Gráfica Central da UniCamp, p.16-31, 1991.

[Valente93]

VALENTE, J.A. (Org.) Diferentes Usos do Computador na Educação. In: Computadores e Conhecimento: Repensando a Educação. Campinas, Gráfica Central da UniCamp, p.1-23, 1993. 
[Vasconcelos98]

VASCONCELOS, A.C. A Psicopedagogia e Informática - Uma Articulação na Clínica. Revista de Psicopedagogia, v.17, n.45, 1998.

[Viana00]

VIANA, A.M.A.; LUCIANO, D.T. A Produção de Texto e a Tecnologia: Avaliando Software Educativo. In: WORKSHOP DE INFORMÁTICA NA EDUCAÇÃO, Curitiba, Brasil, 2000. Anais.

[Vieira00]

VIEIRA, F.M.S. Avaliação de Software Educativo: Reflexões para uma Análise Criteriosa, 2000. Disponível em http://www.edutecnet.com.br. 


\section{ApÊndice A - Glossário dos Termos TÉcnicos Utilizados nos Questionamentos}

A

- Arquivo: Informações que podem ser armazenadas em disquetes, no disco rígido ou em CD-ROMs. Possui um nome e pode possuir uma extensão indicando o tipo de aplicativo a que se relaciona.

B

- Backup de Dados: Armazenamento de cópia dos dados com a finalidade de minimizar perdas no caso de falha nos equipamentos. As cópias de segurança podem ser feitas por exemplo, em disquetes, fitas magnéticas de alta capacidade de armazenamento, em CD-ROMs regraváveis.

D Banco de Dados: Repositório de informações arquivadas em registros. Exemplo: fichas de alunos, contendo seu histórico escolar, comportamento e dados pessoais. As fichas são os registros no banco de dados.

( Boot: Iniciar a operação do computador. Termo derivado da expressão inglesa bootstrap, "dar a partida".

C

- CD-ROM: Sigla que significa "Compact Disk-Ready Only Memory" (Memória apenas para leitura). É um tipo de disco compacto, óptico, para computador, gravado por processo industrial e não regravável, capaz de armazenar grandes quantidades de dados - textos, gráficos, imagens e sons.

Clicar: Pressionar e soltar um botão do mouse sem movimentá-lo.

( CPU: Unidade central de processamento. 
D

- Disco Rígido: É um dispositivo (equipamento) de armazenamento de dados. Em geral, é onde está gravada a maior parte dos programas e das informações do usuário no computador. Também conhecido como HD, hard disk ou winchester.

D Disquete: Disco flexível, com pequena capacidade de armazenamento de dados.

国

D Entrada de Dados: Informações fornecidas aos programas pelo usuário.

$\mathrm{F}$

Ferramenta: Termo genérico utilizado em Informática para se referir a programas.

Funções do Software: Representam as utilidades do software, o conjunto de tarefas que o software oferece ao usuário.

田

- Hardware: Equipamentos que compõem o computador. Exemplos: monitor, teclado, mouse, impressora, placa de som, placa de fax/modem, scanner, CPU, etc.

田

S Ícone: Figura apresentada na tela por meio de uma interface gráfica, geralmente clicável, e usualmente utilizada para identificar ou acionar um recurso do software.

- Interface: É o que intermedia a relação do usuário com o computador. Podem ser: interface de linha de comando (baseada exclusivamente na troca de mensagens escritas 
onde o usuário deve digitar comandos); interface de menus (onde os comandos disponiveis são apresentados na tela do computador na forma de uma lista de itens, dentre os quais se escolhe uma opção, por meio de cliques no mouse ou combinação de teclas); e interface gráfica (onde a interação do usuário com o computador está baseada no amplo emprego de imagens, e não estrita apenas a textos ou caracteres, e que faz uso de um conjunto de ferramentas que inclui janelas, ícones, botões e um meio de apontamento e seleção, como o mouse).

Internet: Rede mundial que interliga computadores.

凹

- Kit Multimídia: Usualmente composto por uma placa de som, caixas acústicas, drive de CD e acompanha disquetes de instalação.

노

Link: Qualquer objeto, palavra ou expressão dentro de um hipertexto que, ao se clicar, permite acessar outras informações. Por exemplo: objetos, palavras ou expressões em uma página na Web.

M

(2) MHZ: Megahertz, e está ligado à velocidade do processamento dos dados no computador.

() Mídia: Meios de comunicação com o usuário. Por exemplo: som, imagens, textos, etc.

D Modem: Modulador/demodulador. Dispositivo capaz de converter dados digitais em sinal analógico, e vice-versa, o que permite estabelecer comunicação a distância entre computadores, por meio de canal analógico (geralmente por linha telefônica convencional). 
- Monitor: A tela do computador que exibe dados.

- Mouse: Dispositivo apontador usado para proporcionar entrada para o computador. Usado normalmente em ambientes gráficos permitindo o controle e manipulação de elementos gráficos e textos em um programa.

- Multimídia: Combinação de textos, gráficos, som e vídeo para apresentar informações. Um computador multimídia é aquele capaz de utilizar estas mídias simultaneamente.

○

- Operações Interativas: Operações onde o usuário pode (e, por vezes, necessita) continuamente intervir e controlar o curso das atividades do computador, fornecendo suas entradas (de dados ou comandos) à medida que observa os efeitos das anteriores.

$\mathbb{P}$

S Periféricos: Os componentes que estão na "periferia" (ao redor) do gabinete. Exemplos: teclado, impressora, etc.

- Placa de Rede: Faz a interface entre o computador e a rede em que ele está inserido. A placa tem um local para a conexão do cabo da rede.

- Placa de Vídeo: Faz a interface entre o computador e o monitor de vídeo.

Placa de som: Faz a interface entre o computador e o sistema de som.

(2) Programa de computador: Seqüência completa de instruções a serem executadas por computador. 
R

- RAM (Random Access Memory): Memória interna ao computador, disponível para execução de programas trazidos do disco rígido, CD-ROM ou disquete. Quando o computador é desligado, o conteúdo da memória RAM é perdido. Em geral, quanto mais RAM estiver disponível, maior será a rapidez do computador na execução dos programas.

- Rede: Refere-se à infra-estrutura para conexão de dois ou mais computadores com o objetivo de permitir que programas (e, consequentemente seus usuários) se comuniquem e/ou compartilhem informações.

S

- Sistema Operacional: Programa de computador responsável pelo gerenciamento dos recursos do computador (processador, memória, disco, etc.).

Software: São programas de computador. Cada software pode conter um conjunto de programas e/ou diversos arquivos para funcionar.

- Software de Autoria: Tipo de software utilizado na produção de cursos, CDs ou páginas na Internet.

S Software de Produtividade: Tipo de software utilizado para editar textos, planilhas de cálculo e banco de dados.

V

Validação dos Dados: Função realizada pelo computador para verificar se os dados fornecidos pelo usuário correspondem ao esperado pelo programa.

S Versão: Estágio do software ao longo do processo de sua criação e desenvolvimento. Em geral, versões mais recentes possuem menos erros e oferecem mais funcionalidade que versões anteriores. 


\section{ApÊNDICE B - MATERIAL AdicionAL}

Abaixo estão relacionados os materiais mencionados neste documento, encontrados em [Gladcheff00g]:

1. Texto completo do artigo a ser publicado na Revista Brasileira de Informática na Educação: "O Software Educacional e a Psicopedagogia no Ensino de Matemática, Direcionado ao Ensino Fundamental";

2. Texto completo de cada uma das entrevistas realizadas com os especialistas da área educacional;

3. Questionário sobre o instrumento de avaliação gerado, utilizado para feedback a fim de refinar o instrumento;

4. lista dos professores do Ensino Fundamental que participaram das avaliações dos produtos de software educacional de Matemática, direcionados ao Ensino Fundamental;

5. Dois relatórios sobre softwares avaliados, como exemplos;

6. Carta enviada aos produtores de software educacional de Matemática, direcionado ao Ensino Fundamental;

7. Questionário enviado aos produtores de software educacional de Matemática, direcionado ao Ensino Fundamental; e,

8. Lista das empresas que responderam aos questionamentos. 
Como observação, gostaríamos de mencionar que os produtos gerados com este trabalho, também podem ser encontrados nas páginas de nosso projeto:

1. Procedimentos para a realização da avaliação dos produtos;

2. Questionários desenvolvidos;

3. Procedimento para a elaboração do relatório sobre o software avaliado; e,

4. Glossário dos termos técnicos utilizados nos questionamentos.

Com isso, o instrumento de avaliação gerado encontra-se acessível a todo professor e/ou pessoa interessada. 